\title{
Selenium-Substituted Non-Fullerene Acceptors: A Route to Superior Operational Stability for Organic Bulk Heterojunction Solar Cells
}

Chiara Labanti ${ }^{\#}$ Min Jae Sung\#, Joel Luke, Sooncheol Kwon, Rhea Kumar, Jisu Hong, Jehan Kim, Artem A. Bakulin, Soon-Ki Kwon, and Yun-Hi Kim*, Ji-Seon Kim*

\#The first two authors contributed equally to this paper.

\section{SUPPORTING EXPERIMENTAL SECTION}

\section{Measurements}

${ }^{1} \mathrm{H}$ NMR and ${ }^{13} \mathrm{C}$ NMR were recorded with a Bruker Advance spectrometer. The mass spectrometer (EI, FAB) were measured using a High-Resolution Mass Spectrometer (Jeol JMS-700). The thermal analysis was performed on a TA TGA 2100 thermogravimetric analyzer in a nitrogen atmosphere at a rate of $10{ }^{\circ} \mathrm{C} / \mathrm{min}$. Differential scanning calorimeter (DSC) was conducted under nitrogen on a TA instrument 2100 DSC. UV-vis absorption spectra was measured by UV-1650PC spectrophotometer. Cyclic voltammetry was performed on an EG and G Parc model $273 \AA$ potentiostat/galvanostat system with a three-electrode cell in a $0.1 \mathrm{M}$ solution of tetrabutylammonium perchlorate $\left(\mathrm{Bu}_{4} \mathrm{NClO}_{4}\right)$ in chloroform at a scan rate of $50 \mathrm{mV} / \mathrm{s}$. A Pt wire was used as the counter electrode, and an $\mathrm{Ag} / \mathrm{AgNO}_{3}(0.1 \mathrm{M})$ electrode was used as the reference electrode.

\section{Material Preparation}

All reactions were carried out in a nitrogen atmosphere using the usual Schlenk techniques. All solvents and reagents were purchased from Aldrich, Alfa Aesar, and TCI. Catalysts used by coupling reactions were purchased from Umicore. The other materials were common commercial level and used as received. All solvents used were further purified prior to use.

\section{Material Synthesis}

Synthesis of ethyl selenopheno[3,2-b]thiophene-5-carboxylate (1). The reaction was followed by literature methods ${ }^{1} .{ }^{1} \mathrm{H}-\mathrm{NMR}\left(\mathrm{CDCl}_{3}, 300 \mathrm{MHz}\right): \delta(\mathrm{ppm}) 8.25(\mathrm{~s}, 1 \mathrm{H}), 7.59-7.57(\mathrm{~d}, \mathrm{~J}=$ $5.2 \mathrm{~Hz}, 1 \mathrm{H}), 7.37-7.35(\mathrm{~d}, \mathrm{~J}=5.9 \mathrm{~Hz}, 1 \mathrm{H}), 4.39(\mathrm{q}, \mathrm{J}=7.1 \mathrm{~Hz}, 2 \mathrm{H}), 1.41(\mathrm{t}, \mathrm{J}=7.1 \mathrm{~Hz}, 3 \mathrm{H})$.

Synthesis of ethyl 2-bromoselenopheno[3,2-b]thiophene-5-carboxylate (2). To solution of ethyl selenopheno[3,2-b]thiophene-5-carboxylate (1) $(30 \mathrm{~g}, 0.11 \mathrm{~mol})$ in DMF (150 mL), NBS $(24.6 \mathrm{~g}, 0.14 \mathrm{~mol})$ was added in portion at room temperature and stirred for $5 \mathrm{~h}$ under nitrogen. After poured at the $\mathrm{H}_{2} \mathrm{O}(300 \mathrm{~mL})$ and extracted with ethyl acetate $(200 \mathrm{~mL} \times 3)$ the organic phase was dried over anhydrous magnesium sulfate $\left(\mathrm{MgSO}_{4}\right)$ and removed solvent. The crude product was purified by silica gel chromatography (hexane-methylene chloride (MC), 7:1). The residue was recrystallized from methanol and $\mathrm{MC}(5: 1)$ to get a white solid powder. Yield 87\%, ${ }^{1} \mathrm{H}-\mathrm{NMR}\left(\mathrm{CD}_{2} \mathrm{Cl}_{2}, 300 \mathrm{MHz}\right): \delta(\mathrm{ppm}) 8.13(\mathrm{~s}, 1 \mathrm{H}), 7.39(\mathrm{~s}, 1 \mathrm{H}), 4.40-4.33(\mathrm{q}, \mathrm{J}=7.1 \mathrm{~Hz}$, $2 \mathrm{H}), 1.42-1.38$ (t, J = 7.1 Hz, 3H); ${ }^{13} \mathrm{C}-\mathrm{NMR}\left(\mathrm{CDCl}_{3}, 500 \mathrm{MHz}\right): 163.5,142.8,140.4,138.1$, 127.5, 125.6, 117.9, 61.6, 14.3. HRMS (FAB ${ }^{+}$: Calcd. for $\mathrm{C}_{9} \mathrm{H}_{7} \mathrm{BrO}_{2} \mathrm{SSe}$ : 337.8515 Found : $\left(\mathrm{M}^{+}\right) 337.8523$. 
Synthesis of 2-bromoselenopheno[3,2-b]thiophene-5-carboxylic acid (3). Ethyl 2bromoselenopheno[3,2-b]thiophene-5-carboxylate (2) (34 g, $74.0 \mathrm{mmol})$ was dissolved in a mixture of tetrahydrofuran (THF) and methanol $(1: 1,300 \mathrm{~mL})$ and $10 \%$ aqueous solution of $\mathrm{NaOH}(100 \mathrm{~mL})$ was added. The reaction was stirred at room temperature for $3 \mathrm{~h}$ under nitrogen. The excess solvents were distilled off and the white solid dissolved in $\mathrm{H}_{2} \mathrm{O}(500 \mathrm{~mL})$. To the aqueous solution, conc. $\mathrm{HCl}$ was slowly added to maintain a $\mathrm{pH}$ between $2-3$. The white precipitate was filtered, washed several times with $\mathrm{H}_{2} \mathrm{O}$ until the filtrate became neutral and vacuum dried to afford the required compound. Yield 78\%, ${ }^{1} \mathrm{H}-\mathrm{NMR}$ (DMSO, $\left.300 \mathrm{MHz}\right): \delta$ (ppm) 8.27 (s, 1H), 7.69 (s, 1H); ${ }^{13} \mathrm{C}-\mathrm{NMR}(\mathrm{DMSO}, 500 \mathrm{MHz}): 164.9,143.1,140.6,128.7$, 127.3, 117.2. ). HRMS (EI ${ }^{+}$: Calcd. for $\mathrm{C}_{7} \mathrm{H}_{3} \mathrm{BrO}_{2} \mathrm{SSe}$ : 309.8202 Found : $\left(\mathrm{M}^{+}\right) 309.8205$.

Synthesis of 2-bromoselenopheno[3,2-b]thiophene (4). To a solution of 2bromoselenopheno[3,2-b]thiophene-5-carboxylic acid (3) (20.0 g, $64.5 \mathrm{mmol})$ in quinoline $(200 \mathrm{~mL}), \mathrm{Cu}(0.82 \mathrm{~g}, 1.29 \mathrm{mmol})$ was added at $220^{\circ} \mathrm{C}$ and stirred for $4 \mathrm{~h}$ under nitrogen. The reaction cooled to room temperature and was added slowly to a $50 \%$ solution of $\mathrm{HCl}(400 \mathrm{~mL})$. It was extracted with chloroform $(300 \mathrm{~mL} \times 3)$ and the organic layer washed several times with $\mathrm{H}_{2} \mathrm{O}$ until the aqueous layer became neutral. The chloroform layer was dried over $\mathrm{MgSO}_{4}$ and removed solvent. The crude product was purified by silica gel chromatography (hexane : $\mathrm{MC}$, 20:1). The residue was recrystallized from methanol and $\mathrm{MC}(5: 1)$ to get a white solid powder. Yield 79\%, ${ }^{1} \mathrm{H}-\mathrm{NMR}\left(\mathrm{CD}_{2} \mathrm{Cl}_{2}, 300 \mathrm{MHz}\right): \delta(\mathrm{ppm}) 7.95-7.93(\mathrm{~d}, \mathrm{~J}=5.8 \mathrm{aHz}, 1 \mathrm{H}), 7.35(\mathrm{~d}, \mathrm{~J}=6.4$ $\mathrm{Hz}, 1 \mathrm{H}), 7.25$ (s, $1 \mathrm{H}) ;{ }^{13} \mathrm{C}-\mathrm{NMR}\left(\mathrm{CDCl}_{3}, 500 \mathrm{MHz}\right): 130.1,126.1,125.1,121.5,119.2$. ). ). HRMS (EI $\left.{ }^{+}\right)$: Calcd. for $\mathrm{C}_{6} \mathrm{H}_{3} \mathrm{BrSSe}: 265.8304$ Found : $\left(\mathrm{M}^{+}\right) 265.8326$.

Synthesis of tributyl(selenopheno[3,2-b]thiophen-2-yl)stannane (5). To solution of 2bromoselenopheno[3,2-b]thiophene (4) (13 g, $48.8 \mathrm{mmol})$ in dry THF (200 $\mathrm{mL}), n$ butyllithium in hexane $(2.5 \mathrm{M})(21.5 \mathrm{~mL}, 53.7 . \mathrm{mmol})$ was dropwise added at $-78^{\circ} \mathrm{C}$ and stirred for $1 \mathrm{~h}$ under nitrogen. At $-78^{\circ} \mathrm{C}$, tributyltin chloride $(19.1 \mathrm{~g}, 58.6 \mathrm{~mol})$ was injected in the mixture and warmed up at room temperature and stirred overnight. After poured at the $\mathrm{H}_{2} \mathrm{O}$ $(200 \mathrm{~mL})$ and extracted with ethyl acetate $(200 \mathrm{~mL} \times 3)$ the organic phase was dried over anhydrous $\mathrm{MgSO}_{4}$ and removed solvent. The crude product was taken to the next reaction without further purification. ${ }^{1} \mathrm{H}-\mathrm{NMR}\left(\mathrm{CD}_{2} \mathrm{Cl}_{2}, 300 \mathrm{MHz}\right): \delta(\mathrm{ppm}) 7.97-7.95(\mathrm{~d}, \mathrm{~J}=6.3 \mathrm{~Hz}$, $1 \mathrm{H}), 7.54(\mathrm{~s}, 1 \mathrm{H}), 7.39(\mathrm{~s}, 1 \mathrm{H}), 1.66-1.63(\mathrm{~m}, 8 \mathrm{H}), 1.45-1.40(\mathrm{~m}, 8 \mathrm{H}), 1.24-1.19(\mathrm{~m}, 8 \mathrm{H}), 0.98-$ $0.94(\mathrm{~m}, 12 \mathrm{H}) ;{ }^{13} \mathrm{C}-\mathrm{NMR}\left(\mathrm{CDCl}_{3}, 500 \mathrm{MHz}\right) 146.7,140.6,140 ., 129.8,129.7,121.6,28.9,27.3$, 13.1, 10.9 .

Synthesis of trimethyl(selenopheno[3,2-b]thiophen-2-yl)silane (6). To solution of 2bromoselenopheno[3,2-b]thiophene (4) $(15 \mathrm{~g}, 56.3 \mathrm{mmol})$ in dry THF $(230 \mathrm{~mL}), n$ butyllithium in hexane $(2.5 \mathrm{M})(24.8 \mathrm{~mL}, 62.0 \mathrm{mmol})$ was dropwise added at $-78^{\circ} \mathrm{C}$ and stirred for $1 \mathrm{~h}$ under nitrogen. At $-78^{\circ} \mathrm{C}$, trimethylsilyl chloride $\left.(7.35 \mathrm{~g}, 67.6 \mathrm{mmol})\right)$ was injected in the mixture and warmed up at room temperature and stirred overnight. After poured at the $\mathrm{H}_{2} \mathrm{O}$ $(200 \mathrm{~mL})$ and extracted with ethyl acetate $(200 \mathrm{~mL} \times 3)$ the organic phase was dried over anhydrous $\mathrm{MgSO}_{4}$ and removed solvent. The crude product was purified by silica gel chromatography (hexane : MC, 20:1). The residue was recrystallized from methanol and MC (5:1) to get a white solid powder. Yield $88 \%,{ }^{1} \mathrm{H}-\mathrm{NMR}\left(\mathrm{CDCl}_{3}, 300 \mathrm{MHz}\right): \delta(\mathrm{ppm}) 7.81-7.79$ $(\mathrm{d}, \mathrm{J}=5.7 \mathrm{~Hz}, 1 \mathrm{H}), 7.38(\mathrm{~d}, \mathrm{~J}=6.3 \mathrm{~Hz}, 1 \mathrm{H}), 7.31(\mathrm{~s}, 1 \mathrm{H}), 0.31(\mathrm{~m}, 9 \mathrm{H}) ;{ }^{13} \mathrm{C}-\mathrm{NMR}\left(\mathrm{CDCl}_{3}, 500\right.$ $\mathrm{MHz})$ 146.2, 143.3, 140.5, 131.2, 128.7, 122.0, 0.0. $\mathrm{MS}_{\text {(EI }}{ }^{+}$): Calcd. for $\mathrm{C}_{9} \mathrm{H}_{12} \mathrm{SSeSi}: 259.9594$ Found : $\left(\mathrm{M}^{+}\right) 260.0871$.

Synthesis of trimethyl(5-(tributylstannyl)selenopheno[3,2-b]thiophen-2-yl)silane (7). To solution of trimethyl(selenopheno[3,2-b]thiophen-2-yl)silane (6) $(5.4 \mathrm{~g}, 20.8 \mathrm{mmol})$ in dry THF $(200 \mathrm{~mL}), n$-butyllithium in hexane $(2.5 \mathrm{M})(9.6 \mathrm{~mL}, 23.9 \mathrm{mmol})$ was dropwise added at $-78{ }^{\circ} \mathrm{C}$ and stirred for $1 \mathrm{~h}$ under nitrogen. At $-78^{\circ} \mathrm{C}$, tributyltin chloride $(8.4 \mathrm{~g}, 26.0 \mathrm{~mol})$ was 
injected in the mixture and warmed up at room temperature and stirred overnight. After poured at the $\mathrm{H}_{2} \mathrm{O}(200 \mathrm{~mL})$ and extracted with ethyl acetate $(200 \mathrm{~mL} \times 3)$, the organic phase was dried over anhydrous $\mathrm{MgSO}_{4}$ and removed solvent. The crude product was taken to the next reaction without further purification. ${ }^{1} \mathrm{H}-\mathrm{NMR}\left(\mathrm{CDCl}_{3}, 300 \mathrm{MHz}\right): \delta(\mathrm{ppm}) 7.42(\mathrm{~s}, 1 \mathrm{H}), 7.23$ $(\mathrm{s}, 1 \mathrm{H}), 1.46-1.44(\mathrm{~m}, 8 \mathrm{H}), 1.23-1.20(\mathrm{~m}, 8 \mathrm{H}), 1.03-0.97(\mathrm{~m}, 8 \mathrm{H}), 0.78-0.73(\mathrm{~m}, 12 \mathrm{H}), 0.2(\mathrm{~m}$, 9H) ; ${ }^{13} \mathrm{C}-\mathrm{NMR}\left(\mathrm{CDCl}_{3}, 500 \mathrm{MHz}\right) 134.0,129.9,129.4,128.5,127.6,29.1,27.4,13.8,11.2$, 11.0, 0.0. HRMS (EI $\left.{ }^{+}\right)$: Calcd. for $\mathrm{C}_{21} \mathrm{H}_{38} \mathrm{SSeSiSn}$ : 550.0651 Found : $\left(\mathrm{M}^{+}\right)$550.0649.

Synthesis of ethyl 4-(propionyloxy)-2,5-bis(selenopheno[3,2-b]thiophen-2-yl)benzoate (8). Tributyl(selenopheno[3,2-b]thiophen-2-yl)stannane (5) (15.0 g, $31.5 \mathrm{mmol})$, ethyl 2,5dibromo-4-(propionyloxy)benzoate $(5 \mathrm{~g}, 13.1 \mathrm{mmol})$ and $\mathrm{Pd}\left(\mathrm{PPh}_{3}\right)_{4}(0.45 \mathrm{~g}, 0.3 \mathrm{mmol})$ were dissolved in a dry toluene $(100 \mathrm{~mL})$ solution. After the mixture was stirred at $100{ }^{\circ} \mathrm{C}$ for $24 \mathrm{~h}$ under nitrogen, the reaction was terminated by $\mathrm{H}_{2} \mathrm{O}(100 \mathrm{~mL})$. The organic layer was separated and the aqueous phase was extracted with $\mathrm{MC}(200 \mathrm{~mL}$ x 3$)$ and dried over anhydrous $\mathrm{MgSO}_{4}$ and removed solvent. The crude product was purified by silica gel chromatography (hexane : ethyl acetate, 8:1), to get a yellow solid powder. Yield 65\%. ${ }^{1} \mathrm{H}-\mathrm{NMR}\left(\mathrm{CD}_{2} \mathrm{Cl}_{2}, 300 \mathrm{MHz}\right): \delta$ (ppm) 8.01-8.00 (d, J=5.7 Hz, 2H), 7.91 (s, 2H), 7.54-7.52 (d, J=6.3 Hz, 2H), $7.36(\mathrm{~s}, 2 \mathrm{H})$, 4.28-4.25 (m, 4H), $1.18-1.13(\mathrm{~m}, 6 \mathrm{H}) ;{ }^{13} \mathrm{C}-\mathrm{NMR}\left(\mathrm{CDCl}_{3}, 500 \mathrm{MHz}\right) 167.5,141.6,141.5$, 138.7, 134.0, 133.6, 132.0, 130.8, 122.4, 122.0, 119.1, 61.8, 13.8. HRMS (EI $\left.{ }^{+}\right)$: Calcd. for $\mathrm{C}_{24} \mathrm{H}_{18} \mathrm{O}_{4} \mathrm{~S}_{2} \mathrm{Se}_{2}: 593.8977$ Found : $\left(\mathrm{M}^{+}\right) 593.9015$.

Synthesis of 4,4,9,9-tetrakis(3-((2-ethylhexyl)oxy)phenyl)-dithieno[2,3-d:2',3'-d']-sindaceno[1,2-b:5,6-b']diselenophene (9). To solution of 1-bromo-3-((2ethylhexyl)oxy)benzene ( $6.3 \mathrm{~g}, 22.2 \mathrm{mmol})$ in dry THF $(25 \mathrm{~mL}), n$-butyllithium in hexane $(2.5$ M) $(8.9 \mathrm{~mL}, 22.2 \mathrm{mmol})$ was dropwise added at $-78^{\circ} \mathrm{C}$ and stirred for $1 \mathrm{~h}$ under nitrogen. The solution of compound (8) $(2.7 \mathrm{~g}, 4.55 \mathrm{mmol})$ in THF $(45 \mathrm{~mL})$ was dropwise at the reaction mixture and warmed to room temperature and stirred overnight. After poured at the $\mathrm{H}_{2} \mathrm{O}(50$ $\mathrm{mL})$ and extracted with ethyl acetate $(30 \mathrm{~mL} \times 3)$ the organic phase was dried over anhydrous $\mathrm{MgSO}_{4}$ and removed solvent. The crude mixture was dissolved at acetic acid $(50 \mathrm{~mL})$ and heated at $120^{\circ} \mathrm{C}$ and stirred $2 \mathrm{~h}$. After poured at the $\mathrm{H}_{2} \mathrm{O}(50 \mathrm{~mL})$ and extracted with $\mathrm{MC}(50$ $\mathrm{mL} \times 3$ ) the organic phase was dried over anhydrous $\mathrm{MgSO}_{4}$ and removed solvent. The crude product was purified by silica gel chromatography (hexane-MC, gradient from 10:1 to 6:1). The residue was recrystallized from methanol and $\mathrm{MC}(5: 1)$ to get a yellow solid powder. Yield 40\%. ${ }^{1} \mathrm{H}-\mathrm{NMR}\left(\mathrm{CD}_{2} \mathrm{Cl}_{2}, 300 \mathrm{MHz}\right): \delta(\mathrm{ppm}) 7.87-7.85(\mathrm{~d}, \mathrm{~J}=5.8 \mathrm{~Hz}, 2 \mathrm{H}), 7.56(\mathrm{~s}, 2 \mathrm{H}), 7.54-$ $7.52(\mathrm{~d}, \mathrm{~J}=5.7 \mathrm{~Hz}, 2 \mathrm{H}), 7.18-7.15(\mathrm{~d}, \mathrm{~J}=8.0 \mathrm{~Hz}, 4 \mathrm{H}), 6.87-6.86(\mathrm{~m}, 4 \mathrm{H}), 6.83-6.78(\mathrm{~m}, 8 \mathrm{H})$, 3.78-3.76 (m, 8H), 1.66-1.65 (m, 4H), $1.28(\mathrm{~m}, 32 \mathrm{H}), 0.90-0.85(\mathrm{~m}, 24 \mathrm{H}) . ;{ }^{13} \mathrm{C}-\mathrm{NMR}\left(\mathrm{CD}_{2} \mathrm{Cl}_{2}\right.$, $500 \mathrm{MHz}$ ): 159.4, 152.9, 148.5, 144.3, 143.1, 129.3, 120.2, 117.9, 117.0, 115.2, 112.9, 70.5, 63.5, 39.2, 30.4, 29.0, 23.7, 23.0, 14.0, 11.0. . HRMS $\left(\mathrm{FAB}^{+}\right)$: Calcd. for $\mathrm{C}_{76} \mathrm{H}_{90} \mathrm{O}_{4} \mathrm{~S}_{2} \mathrm{Se}_{2}$ : 1290.4611 Found : $\left(\mathrm{M}^{+}\right)$1290.4661.

Synthesis of 4,4,9,9 -tetrakis(3-((2-ethylhexyl)oxy)phenyl)-dithieno[2,3-d:2',3'-d']-sindaceno[1,2-b:5,6-b']diselenophene-3,9-dicarbaldehyde (10). To solution of compound (9) $(3 \mathrm{~g}, 23.2 \mathrm{mmol})$ in dry 1,2-dichloroethane $(150 \mathrm{~mL})$ and $\mathrm{DMF}(1.2 \mathrm{~mL}, 16.3 \mathrm{mmol}), \mathrm{POCl}_{3}$ $(1.4 \mathrm{~g}, 8.8 \mathrm{mmol})$ was dropwise added at $-0{ }^{\circ} \mathrm{C}$ and was stirred at $85^{\circ} \mathrm{C}$ for $24 \mathrm{~h}$ under nitrogen. After poured at the $\mathrm{H}_{2} \mathrm{O}(50 \mathrm{~mL})$, and extracted with $\mathrm{MC}(100 \mathrm{~mL} \times 3)$ the organic phase was dried over anhydrous $\mathrm{MgSO}_{4}$ and removed solvent. The crude product was purified by silica gel chromatography (hexane- ethyl acetate, 10:1). The residue was recrystallized from hexane and ethyl acetate (4:1) to get an orange solid powder. Yield $72 \%{ }^{1} \mathrm{H}-\mathrm{NMR}\left(\mathrm{CD}_{2} \mathrm{Cl}_{2}, 300 \mathrm{MHz}\right)$ : $\delta(\mathrm{ppm}) 9.81(\mathrm{~s}, 2 \mathrm{H}), 8.25(\mathrm{~s}, 2 \mathrm{H}), 7.75(\mathrm{~s}, 2 \mathrm{H}), 7.24(\mathrm{t}, \mathrm{J}=8.2 \mathrm{~Hz}, 4 \mathrm{H}), 6.87-6.83(\mathrm{~m}, 12 \mathrm{H})$, 3.81-3.79 (m, 8H), 1.68-1.56 (m, 4H), $1.28(\mathrm{~m}, 32 \mathrm{H}), 0.91-0.86(\mathrm{~m}, 24 \mathrm{H}) . ;{ }^{13} \mathrm{C}-\mathrm{NMR}\left(\mathrm{CD}_{2} \mathrm{Cl}_{2}\right.$, $500 \mathrm{MHz}): 183.7,159.7,154.3,149.4,148.9,148.7,143.3,143.0,139.3,136.4,132.7,129.7$, 
119.9, 118.1, 114.9, 113.0, 70.6, 63.6, 39.2, 30.3, 28.9, 23.7, 23.0, 13.8, 10.7. HRMS $\left(\mathrm{FAB}^{+}\right)$: Calcd. for $\mathrm{C}_{78} \mathrm{H}_{90} \mathrm{O}_{6} \mathrm{~S}_{2} \mathrm{Se}_{2}$ : 1346.4509 Found : $\left(\mathrm{M}^{+}\right) 1346.4480$.

Synthesis of 3,9-bis(2-methylene-(3-(1,1-dicyanomethylene)-indanone))- 4,4,9,9 -tetrakis(3((2-ethylhexyl)oxy)phenyl)-dithieno[2,3-d:2',3'-d']-s-indaceno[1,2-b:5,6-b']diselenophene

(SeOut). 2-(3-Oxo-2,3-dihydro-1H-inden-1-ylidene)malononitrile $(0.20 \mathrm{~g}, 1.0 \mathrm{mmol})$ and sodium acetate $(0.1 \mathrm{~g}, 1.3 \mathrm{mmol})$ were dissolved in acetic acid $(18 \mathrm{~mL})$ and heated at $80^{\circ} \mathrm{C}$ for $5 \mathrm{~min}$. The solution of compound (10) $(0.3 \mathrm{~g}, 0.2 \mathrm{mmol})$ in toluene $(12 \mathrm{~mL})$ was injected into the mixture and stirred overnight at $100{ }^{\circ} \mathrm{C}$ under nitrogen. The mixture was cooled down to room temperature, and then poured into ice $\mathrm{H}_{2} \mathrm{O}(50 \mathrm{~mL})$. After extraction with $\mathrm{MC}$ and the solution of sodium chloride, the organic phase was dried over anhydrous $\mathrm{MgSO}_{4}$ and removed solvent. These solid was dissolved in small amount MC and precipitate to methanol. The residue was recrystallized from acetone and $\mathrm{MC}(10: 1)$ to get an indigo solid powder. Yield 82\%. ${ }^{1} \mathrm{H}-\mathrm{NMR}\left(\mathrm{CD}_{2} \mathrm{Cl}_{2}, 300 \mathrm{MHz}\right): \delta(\mathrm{ppm}) 9.05(\mathrm{~s}, 2 \mathrm{H}), 8.71-8.69(\mathrm{~d}, \mathrm{~J}=6.9 \mathrm{~Hz}, 2 \mathrm{H}), 8.31(\mathrm{~s}$, $2 \mathrm{H}), 7.88-7.80(\mathrm{~m}, 8 \mathrm{H}), 7.29-7.24(\mathrm{t}, \mathrm{J}=8.0 \mathrm{~Hz}, 4 \mathrm{H}), 6.93-6.86(\mathrm{~m}, 12 \mathrm{H}), 3.88-3.84(\mathrm{~m}, 8 \mathrm{H})$, $1.7(\mathrm{~m}, 4 \mathrm{H}), 1.59-1.25(\mathrm{~m}, 32 \mathrm{H}), 0.91-0.86(\mathrm{~m}, 24 \mathrm{H}) . ;{ }^{13} \mathrm{C}-\mathrm{NMR}\left(\mathrm{CD}_{2} \mathrm{Cl}_{2}, 500 \mathrm{MHz}\right): 164.3$, $159.7,152.5,143.1,141.0,141.0,136.8,135.2,134.4,129.7,125.2,123.5,119.8,118.8,114.9$, $114.6,113.5,113.4,70.6,63.7,39.3,30.5,28.9,28.9,23.6,23.0,22.9,13.8,10.8$. HRMS $\left(\mathrm{FAB}^{+}\right)$: Calcd. for $\mathrm{C}_{102} \mathrm{H}_{98} \mathrm{~N}_{4} \mathrm{O}_{6} \mathrm{~S}_{2} \mathrm{Se}_{2}$ : 1698.5258 Found : $\left(\mathrm{M}^{+}\right)$1698.5272.

Synthesis of 3,9-bis(2-methylene-((3-(1,1-dicyanomethylene)-6/7-methyl)-indanone))- 4,4,9,9 -tetrakis(3-((2-ethylhexyl)oxy)phenyl)-dithieno[2,3-d:2',3'-d']-s-indaceno[1,2-b:5,6-

b']diselenophene (SeOutMe). 2-(5-Methyl-3-oxo-2,3-dihydro-1H-inden-1ylidene)malononitrile $(0.21 \mathrm{~g}, 1.0 \mathrm{mmol})$ and sodium acetate $(0.1 \mathrm{~g}, 1.3 \mathrm{mmol})$ were dissolved in acetic acid $(18 \mathrm{~mL})$ and heated at $80{ }^{\circ} \mathrm{C}$ for $5 \mathrm{~min}$. The solution of compound (10) $(0.3 \mathrm{~g}, 0.2$ $\mathrm{mmol})$ in toluene $(12 \mathrm{~mL})$ was injected into the mixture and stirred overnight at $100^{\circ} \mathrm{C}$ under nitrogen. The mixture was cooled down to room temperature, and then poured into ice $\mathrm{H}_{2} \mathrm{O}(50$ $\mathrm{mL}$ ). After extraction with $\mathrm{MC}$ and the solution of sodium chloride, the organic phase was dried over anhydrous $\mathrm{MgSO}_{4}$ and removed solvent. These solid was dissolved in small amount $\mathrm{MC}$ and precipitate to methanol. The residue was recrystallized from acetone and MC (10:1) to get an indigo solid powder. Yield $80 \%$. ${ }^{1} \mathrm{H}-\mathrm{NMR}\left(\mathrm{CD}_{2} \mathrm{Cl}_{2}, 300 \mathrm{MHz}\right): \delta(\mathrm{ppm}) 9.01(\mathrm{~s}, 2 \mathrm{H})$, 8.59-8.56 (d, J=8.1 Hz, 2H), $8.29(\mathrm{~s}, 2 \mathrm{H}), 7.80(\mathrm{~s}, 2 \mathrm{H}), 7.68(\mathrm{~m}, 4 \mathrm{H}), 7.29-7.24$ (t, J=7.9 Hz, $4 \mathrm{H}), 6.93-6.86(\mathrm{~m}, 12 \mathrm{H}), 3.88-3.84(\mathrm{~m}, 8 \mathrm{H}), 2.56(\mathrm{~s}, 6 \mathrm{H}), 1.71-1.70(\mathrm{~m}, 4 \mathrm{H}), 1.56-1.25(\mathrm{~m}$, 32H), 0.91-0.82 (m, 24H). ; ${ }^{13} \mathrm{C}-\mathrm{NMR}\left(\mathrm{CDCl}_{3}, 500 \mathrm{MHz}\right): 206.3,159.7,156.6,149.5,149.4$, 149.0, 144.3, 143.9, 143.3, 143.2, 131.0, 129.7, 126.1, 124.8, 123.0, 121.8, 119.8, 118.7, 114.9, 114.8, 114.7, 113.5, 113.4, 78.4, 70.6, 63.7, 39.3, 30.5, 30.3, 28.9, 28.9, 23.6, 23.0, 23.0,13.8, 10.8. HRMS (FAB ${ }^{+}$: Calcd. for $\mathrm{C}_{104} \mathrm{H}_{102} \mathrm{~N}_{4} \mathrm{O}_{6} \mathrm{~S}_{2} \mathrm{Se}_{2}$ : 1726.5571 Found : $\left(\mathrm{M}^{+}\right) 1726.5562$.

Synthesis of ethyl 4-(propionyloxy)-2,5-bis(5-(trimethylsilyl) selenophene[3,2-b]thiophen-2yl)benzoate (11). The reaction was followed by compound (8) methods. Yield 57\%. ${ }^{1} \mathrm{H}-\mathrm{NMR}$ $\left(\mathrm{CDCl}_{3}, 300 \mathrm{MHz}\right): \delta(\mathrm{ppm}) 7.64(\mathrm{~s}, 2 \mathrm{H}), 7.25-7.23(\mathrm{~m}, 4 \mathrm{H}), 4.08-4.06(\mathrm{~m}, 4 \mathrm{H}), 1.00-0.96(\mathrm{~m}$, $6 \mathrm{H}), 0.21-0.19$ (m, 18H). ; ${ }^{13} \mathrm{C}-\mathrm{NMR}\left(\mathrm{CDCl}_{3}, 500 \mathrm{MHz}\right): 167.7,146.3,145.8,141.4,135.6$, 133.8, 131.9, 128.7, 121.6, 61.9, 14.0, 0.0. . HRMS (EI ${ }^{+}$: Calcd. for $\mathrm{C}_{24} \mathrm{H}_{18} \mathrm{O}_{4} \mathrm{~S}_{2} \mathrm{Se}_{2} \mathrm{Si}_{2}$ : 737.9767 Found : $\left(\mathrm{M}^{+}\right) 737.9764$.

Synthesis of 4,4,9,9 -tetrakis(3-((2-ethylhexyl)oxy)phenyl)-diseleno [2,3-d:2',3'-d']-sindaceno[1,2-b:5,6-b']dithiophene (12). The reaction was followed by compound (9) methods. Yield 45\%. ${ }^{1} \mathrm{H}-\mathrm{NMR}\left(\mathrm{CDCl}_{3}, 300 \mathrm{MHz}\right): \delta(\mathrm{ppm}) 7.48(\mathrm{~s}, 2 \mathrm{H}), 7.34-7.32(\mathrm{~d}, \mathrm{~J}=5.2 \mathrm{~Hz}, 2 \mathrm{H})$, 7.26-7.24 (d, J=5.2 Hz, 2H), 7.19-7.14 (t, J=5.2 Hz, 4H), 6.91-6.90 (m, 4H), 6.82-6.78 (m, 8H), 3.78-3.76 (m, 8H), $1.56(\mathrm{~m}, 4 \mathrm{H}), 1.44-1.24(\mathrm{~m}, 32 \mathrm{H}), 0.90-0.85(\mathrm{~m}, 24 \mathrm{H}) . ;{ }^{13} \mathrm{C}-\mathrm{NMR}\left(\mathrm{CD}_{2} \mathrm{Cl}_{2}\right.$, $500 \mathrm{MHz})$ : 159.3, 152.5, 147.2, 144.8, 144.0, 140.2, 138.3, 134.7, 129.2, 126.0, 120.4, 117 ., 
115.4, 113.0, 70.5, 64.7, 39.2, 30.4, 29.0, 24.7, 23.0, 14.0, 11.0. HRMS (FAB ${ }^{+}$): Calcd. for $\mathrm{C}_{76} \mathrm{H}_{90} \mathrm{O}_{4} \mathrm{~S}_{2} \mathrm{Se}_{2}: 1290.4611$ Found : $\left(\mathrm{M}^{+}\right)$1290.4641.

Synthesis of 4,4,9,9 -tetrakis(3-((2-ethylhexyl)oxy)phenyl)-diseleno [2,3-d:2',3'-d']-sindaceno[1,2-b:5,6-b']dithiophene-3,9-dicarbaldehyde (13). The reaction was followed by compound (10) methods. Yield 78\%. ${ }^{1} \mathrm{H}-\mathrm{NMR}\left(\mathrm{CDCl}_{3}, 300 \mathrm{MHz}\right): \delta(\mathrm{ppm}) 9.9(\mathrm{~s}, 2 \mathrm{H}), 7.59$ $(\mathrm{s}, 2 \mathrm{H}), 7.75(\mathrm{~s}, 2 \mathrm{H}), 7.28-7.18(\mathrm{t}, \mathrm{J}=7.7 \mathrm{~Hz}, 4 \mathrm{H}), 6.84-6.78(\mathrm{~m}, 12 \mathrm{H}), 3.79-3.77(\mathrm{~m}, 8 \mathrm{H}), 1.67-$ $1.56(\mathrm{~m}, 4 \mathrm{H}), 1.40-1.31(\mathrm{~m}, 32 \mathrm{H}), 0.90-0.85(\mathrm{~m}, 24 \mathrm{H}) . ;{ }^{13} \mathrm{C}-\mathrm{NMR}\left(\mathrm{CDCl}_{3}, 500 \mathrm{MHz}\right): 182.5$, 159.5, 153.9, 150.1 , 146.6, 143.8, 142.9, 135.4, 134.8, 130.9, 129.6, 124.3, 120.9, 120.2 116.0, 115.3, 70.6, 39.2, 30.3, 28.9, 27.1, 23.7, 23.0, 14.0, 11.0. HRMS $\left(\mathrm{FAB}^{+}\right)$: Calcd. for $\mathrm{C}_{78} \mathrm{H}_{90} \mathrm{O}_{6} \mathrm{~S}_{2} \mathrm{Se}_{2}$ : 1346.4509 Found : $\left(\mathrm{M}^{+}\right)$1346.4523.

Synthesis of 3,9-bis(2-methylene-(3-(1,1-dicyanomethylene)-indanone))- 4,4,9,9 -tetrakis(3((2-ethylhexyl)oxy)phenyl)-diseleno[2,3-d:2',3'-d']-s-indaceno[1,2-b:5,6-b'] dithiophene

(SeIn). 2-(3-Oxo-2,3-dihydro-1H-inden-1-ylidene)malononitrile $(0.20 \mathrm{~g}, 1.0 \mathrm{mmol})$ and sodium acetate $(0.1 \mathrm{~g}, 1.3 \mathrm{mmol})$ were dissolved in acetic acid $(18 \mathrm{~mL})$ and heated at $80^{\circ} \mathrm{C}$ for $5 \mathrm{~min}$. The solution of compound (13) $(0.3 \mathrm{~g}, 0.2 \mathrm{mmol})$ in toluene $(12 \mathrm{~mL})$ was injected into the mixture and stirred overnight at $100{ }^{\circ} \mathrm{C}$ under nitrogen. The mixture was cooled down to room temperature, and then poured into ice $\mathrm{H}_{2} \mathrm{O}(50 \mathrm{~mL})$. After extraction with $\mathrm{MC}$ and the solution of sodium chloride, the organic phase was dried over anhydrous $\mathrm{MgSO}_{4}$ and removed solvent. These solid was dissolved in small amount MC and precipitate to methanol. The residue was recrystallized from acetone and $\mathrm{MC}(10: 1)$ to get an indigo solid powder. Yield 84\%. ${ }^{1} \mathrm{H}-\mathrm{NMR}\left(\mathrm{CD}_{2} \mathrm{Cl}_{2}, 300 \mathrm{MHz}\right): \delta(\mathrm{ppm}) 8.90(\mathrm{~s}, 2 \mathrm{H}), 8.72-8.69(\mathrm{~d}, \mathrm{~J}=7.8 \mathrm{~Hz}, 2 \mathrm{H}), 8.21$ (s, 2H), 7.91-7.77 (m, 6H), 7.7 (s, 2H), 7.29-7.28-7.22 (t, J=8.0 Hz, 4H), 7.0 (s, 4H), 6.90-6.83 $(\mathrm{m}, 8 \mathrm{H}), 3.91-3.89(\mathrm{~m}, 8 \mathrm{H}), 1.7(\mathrm{~m}, 4 \mathrm{H}), 1.57-1.26(\mathrm{~m}, 32 \mathrm{H}), 0.88-0.84(\mathrm{~m}, 24 \mathrm{H}) . ;{ }^{13} \mathrm{C}-\mathrm{NMR}$ $\left.\mathrm{CD}_{2} \mathrm{Cl}_{2}, 500 \mathrm{MHz}\right): 187.8,160.3,159.7,154.8,148.9,148.2,142.7,140.0,139.5,139.3,139.0$, 137.6, 136.9, 135.1, 134.4, 129.7, 125.1, 123.6, 123.0, 119.8, 119.8, 118.7, 115.0, 115.0, 114.7, 114.6, 113.7, 113.6, 70.6, 70.5, 69.5, 39.3, 30.3, 29.0, 28.9, 23.7, 23.0, 22.9, 13.8, 10.8. HRMS $\left(\mathrm{FAB}^{+}\right)$: Calcd. for $\mathrm{C}_{102} \mathrm{H}_{98} \mathrm{~N}_{4} \mathrm{O}_{6} \mathrm{~S}_{2} \mathrm{Se}_{2}$ : 1698.5258 Found : $\left(\mathrm{M}^{+}\right)$1698.5294.

Synthesis of 3,9-bis(2-methylene-((3-(1,1-dicyanomethylene)-6/7-methyl)-indanone))- 4,4,9,9 -tetrakis(3-((2-ethylhexyl)oxy)phenyl)-diseleno[2,3-d:2',3'-d']-s-indaceno[1,2-b:5,6-

b']dithiophene (SeInMe). 2-(5-Methyl-3-oxo-2,3-dihydro-1H-inden-1-ylidene)malononitrile $(0.1 \mathrm{~g}, 1.3 \mathrm{mmol})$ were dissolved in acetic acid $(18 \mathrm{~mL})$ and heated at $80^{\circ} \mathrm{C}$ for $5 \mathrm{~min}$. The solution of compound (13) $(0.3 \mathrm{~g}, 0.2 \mathrm{mmol})$ in toluene $(12 \mathrm{~mL})$ was injected into the mixture and stirred overnight at $100{ }^{\circ} \mathrm{C}$ under nitrogen. The mixture was cooled down to room temperature, and then poured into ice $\mathrm{H}_{2} \mathrm{O}(50 \mathrm{~mL})$. After extraction with $\mathrm{MC}$ and the solution of sodium chloride, the organic phase was dried over anhydrous $\mathrm{MgSO}_{4}$ and removed solvent. These solid was dissolved in small amount MC and precipitate to methanol. The residue was recrystallized from acetone and $\mathrm{MC}(10: 1)$ to get an indigo solid powder. Yield 85\%. ${ }^{1} \mathrm{H}-\mathrm{NMR}$ $\left(\mathrm{CD}_{2} \mathrm{Cl}_{2}, 300 \mathrm{MHz}\right): \delta(\mathrm{ppm}) 8.87(\mathrm{~s}, 2 \mathrm{H}), 8.59-8.56(\mathrm{~d}, \mathrm{~J}=8.2 \mathrm{~Hz}, 2 \mathrm{H}), 8.20(\mathrm{~s}, 2 \mathrm{H}), 7.80$ (s, 2H), $7.71(\mathrm{~m}, 4 \mathrm{H}), 7.64-7.61(\mathrm{~d}, \mathrm{~J}=10.5 \mathrm{~Hz}, 2 \mathrm{H}), 7.27-7.22$ (t, J=8.0 Hz, 4H), 7.01-6.99 (s, 4H), 6.93-6.83 (m, 8H), 3.91-3.89 (m, 8H), 2.56 (s, 6H), 1.7-1.70 (m, 4H), 1.57-1.25 (m, 32H), 0.91$0.82(\mathrm{~m}, 24 \mathrm{H}) . ;{ }^{13} \mathrm{C}-\mathrm{NMR}\left(\mathrm{CDCl}_{3}, 500 \mathrm{MHz}\right): 187.9,160.4,159.7,154.7,154.3,148.8,147.8$, $146.4,142.7,142.0,139.2$, 139.0, 137.7, 137.2, 136.0, 129.7, 125.0, 123.9, 123.5, 119.8, 119.8, 118.6, 115.0, 115.0, 114.8, 114.7, 113.7, 113.7, 70.6, 70.5, 68.6, 39.3, 30.3, 29.0, 28.9, 24.7, 23.6, 23.0, 23.0, 21.7, 13.8, 10.8. . HRMS $\left(\mathrm{FAB}^{+}\right)$: Calcd. for $\mathrm{C}_{104} \mathrm{H}_{102} \mathrm{~N}_{4} \mathrm{O}_{6} \mathrm{~S}_{2} \mathrm{Se}_{2}: 1726.5571$ Found : $\left(\mathrm{M}^{+}\right) 1726.5593$. 


\section{Transient Absorption analysis}

The observed influence of the Se position on the degree of D/A mixing is reinforced by charge separation kinetics obtained by transient absorption (TA) spectroscopy. Figures S58a and S59a show the complete TA spectra for blends of PBDB-T with SeIn and SeOut, following excitation pulses of $725 \mathrm{~nm}$ and $720 \mathrm{~nm}$ respectively. Both spectra show a large ground-state bleach in the wavelength region above $700 \mathrm{~nm}$. In each case this feature is assigned to the NFA exciton due to its overlap with the most prominent peak in the ground-state spectrum, its steady decay immediately after pump excitation and also because of the negligible absorption by PBDB-T in this region. The spectra also contain two further negative features between $525 \mathrm{~nm}$ and 680 $\mathrm{nm}$. As they mirror the steady-state spectra of components, we assign them to a combination of ground-state bleach contributions from both the NFA and PBDB-T.

Global analysis (GA) was applied to reliably and quantitatively deconvolute the overlapping spectra of exciton and charges present in each blend. For the analysis, the long-lived species were assumed to represent free charge carriers and short-lived species were interpreted as excitons. Their distinct spectra extracted after the GA fitting procedure [https://doi.org/10.1021/jp200466y] are shown in figures S58b and S59b for SeIn and SeOut respectively. In both cases, the charge component was restricted as a snapshot of the TA spectrum averaged over late times (3-6 ns), while the exciton component was freely optimized. The optimized exciton spectrum clearly matches the TA spectrum at $0-2$ ps for both blends, thus verifying the validity of the approach and its conclusions. The corresponding kinetics of the components are shown in Figure $2 \mathrm{~d}$ of the main manuscript. 


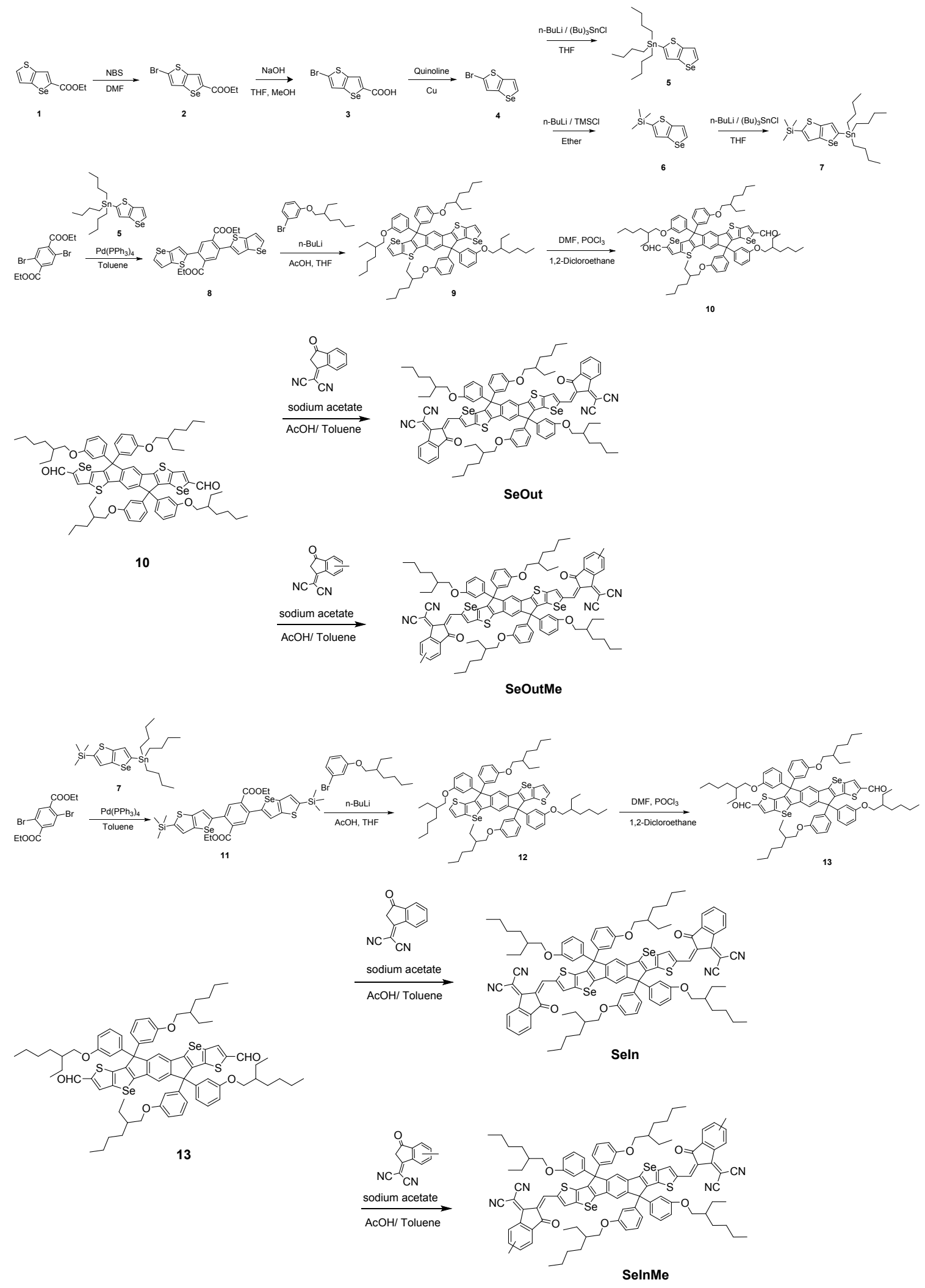

Figure S1. Synthetic Scheme of SeOut, SeOutMe, SeIn, and SeInMe 


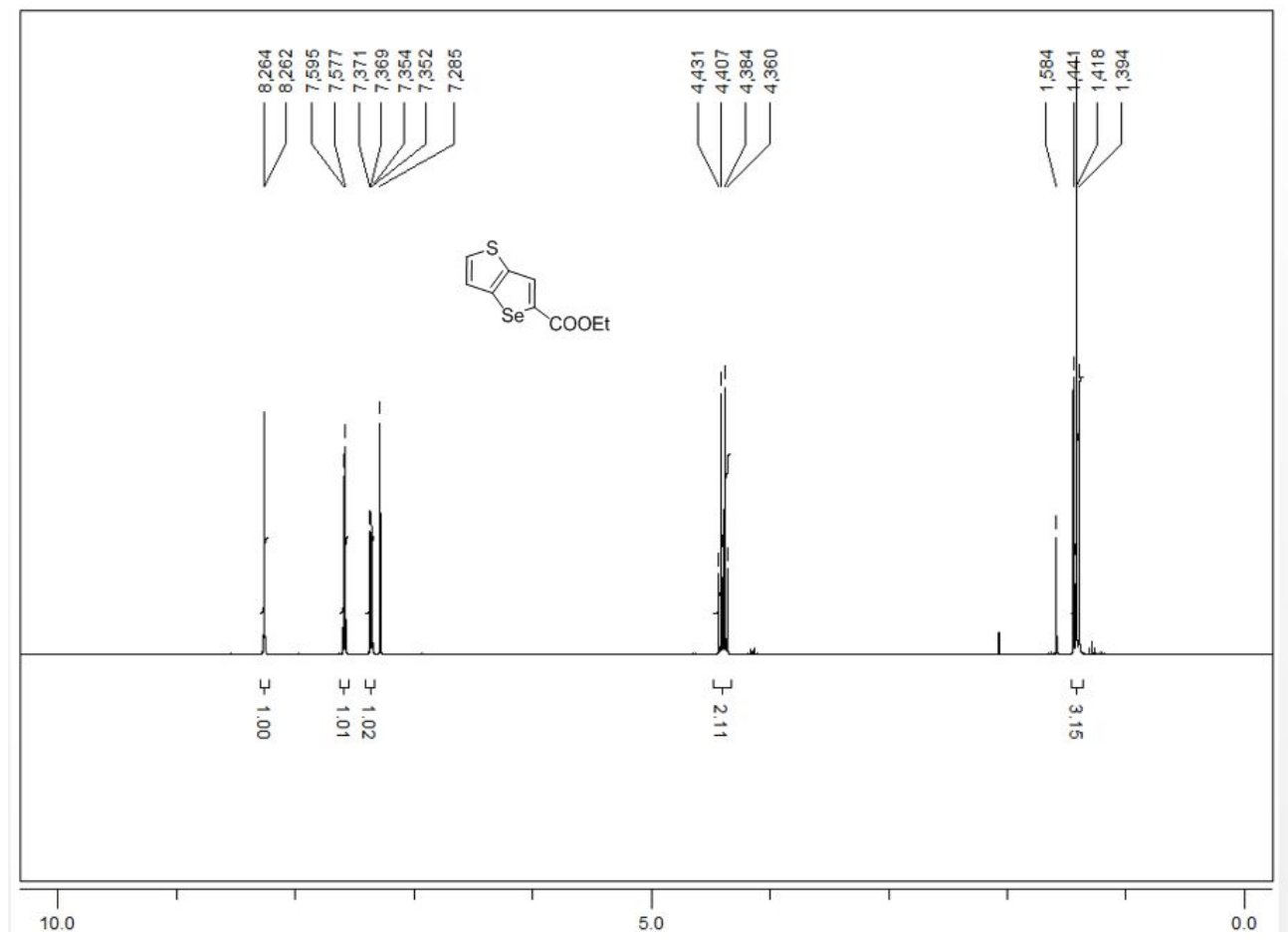

Figure S2. ${ }^{1} \mathrm{H}-\mathrm{NMR}$ of compound (1)

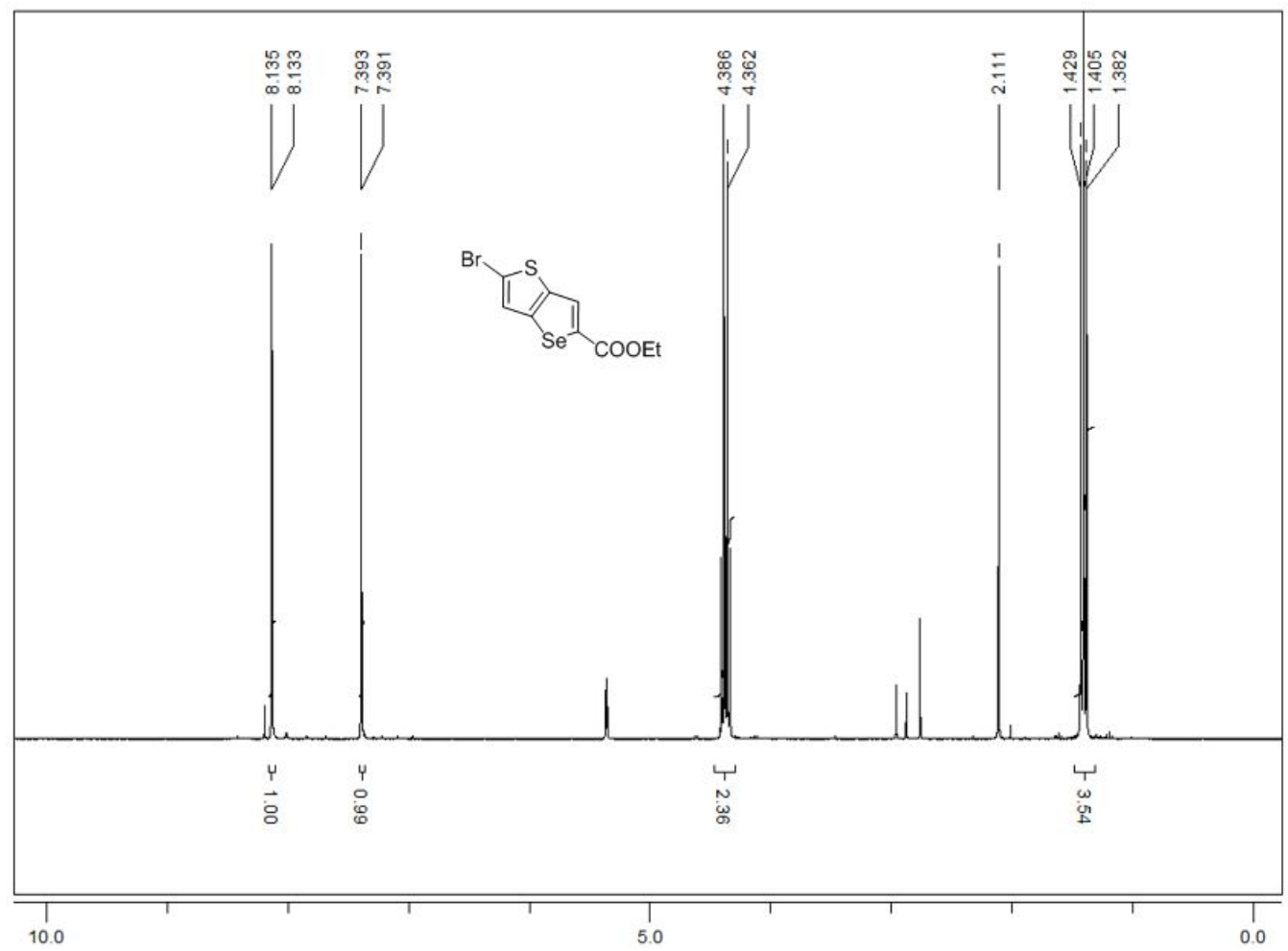

Figure S3. ${ }^{1} \mathrm{H}-\mathrm{NMR}$ of compound (2) 


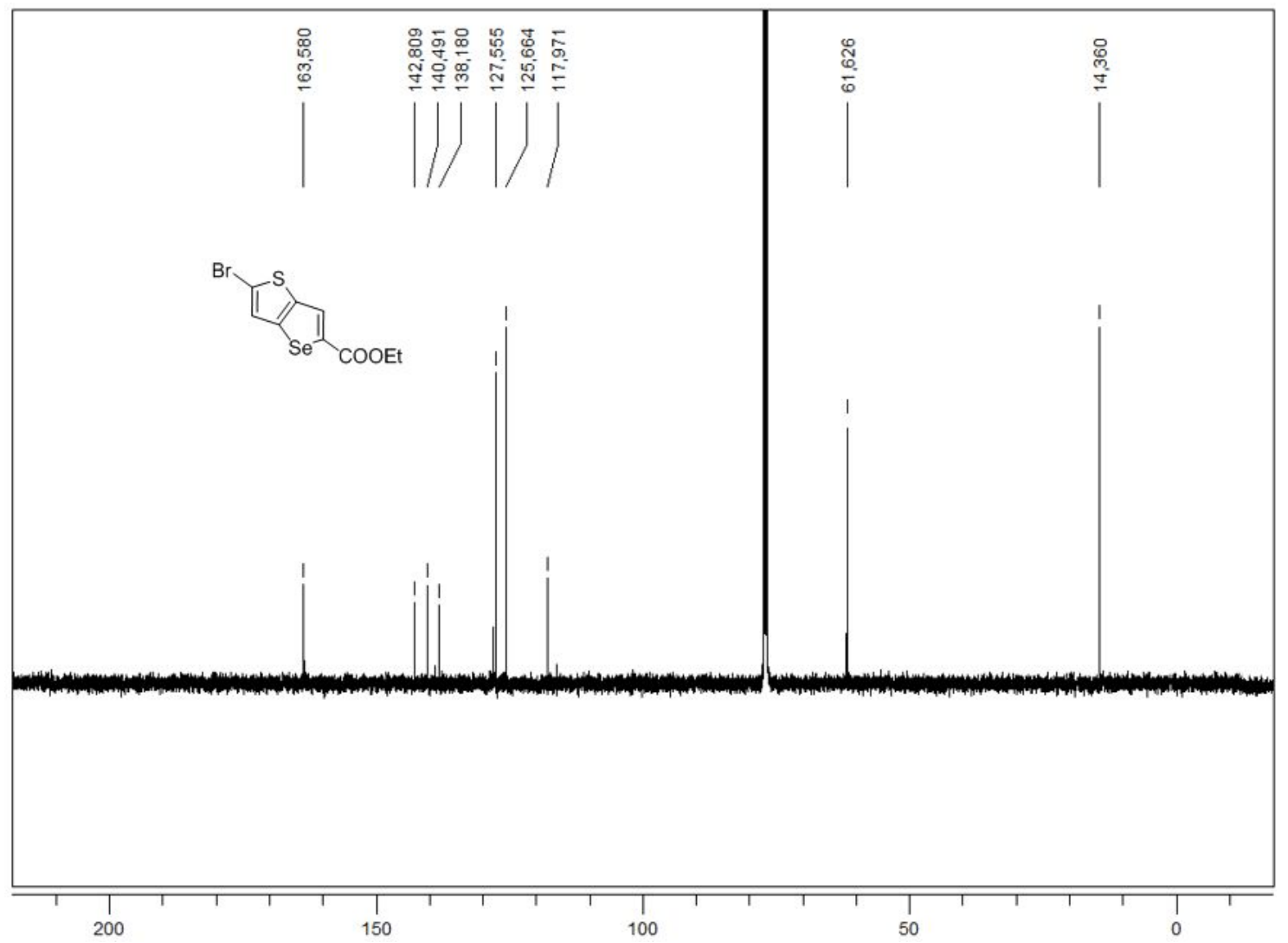

Figure S4. ${ }^{13} \mathrm{C}-\mathrm{NMR}$ of compound (2)

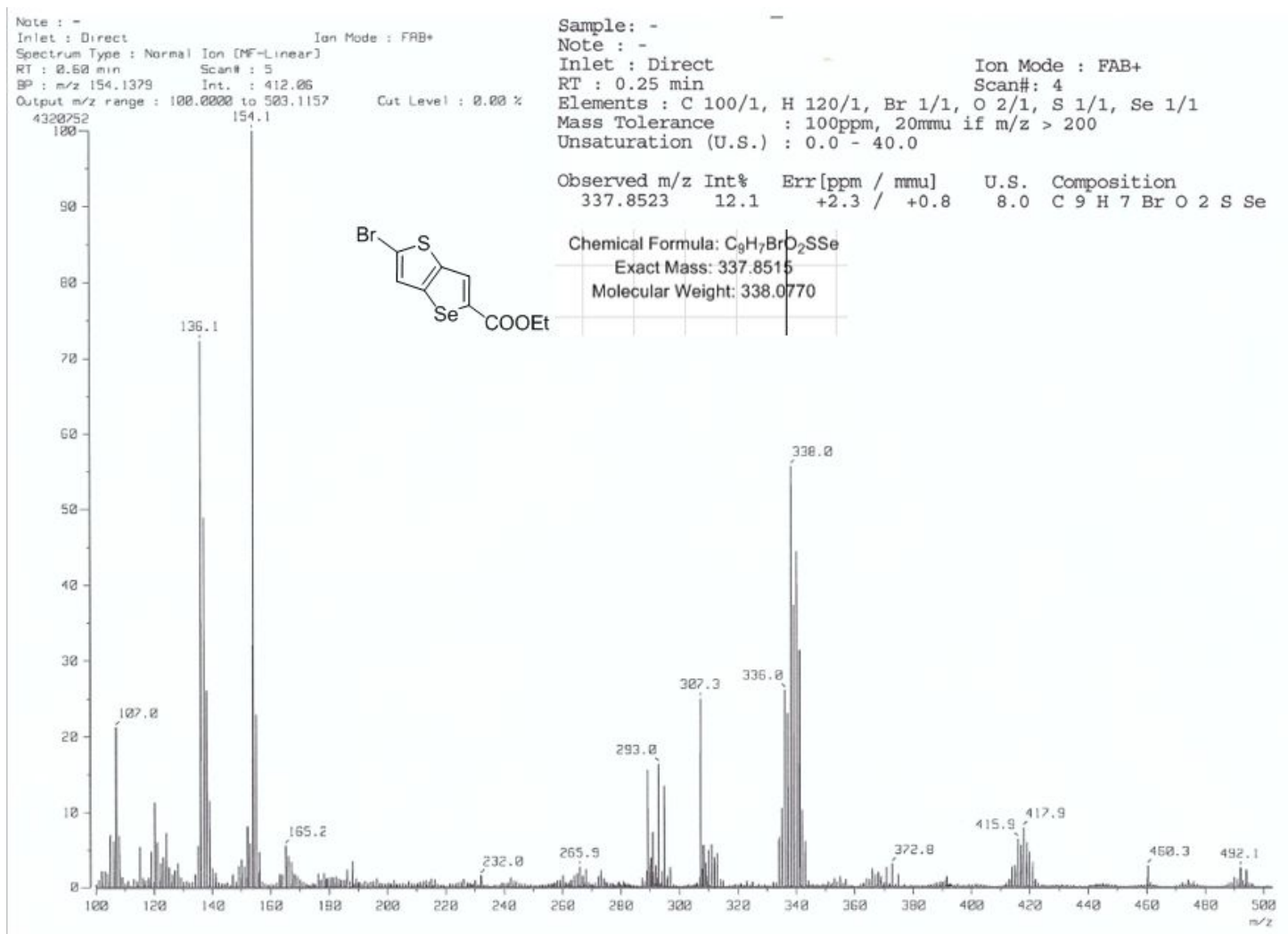

Figure S5. Mass spectrum of compound (2) 


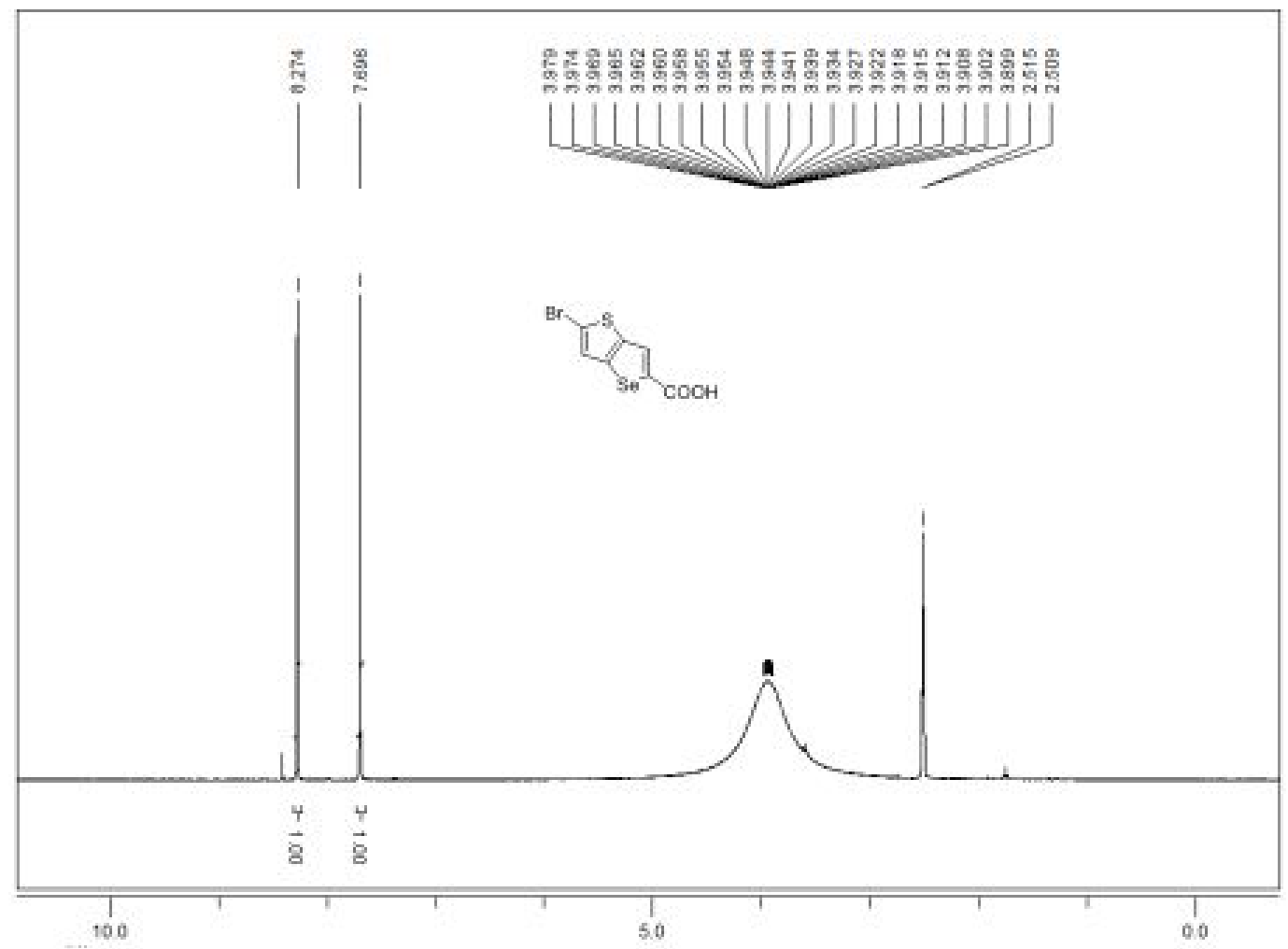

Figure S6. ${ }^{1} \mathrm{H}-\mathrm{NMR}$ of compound (3)

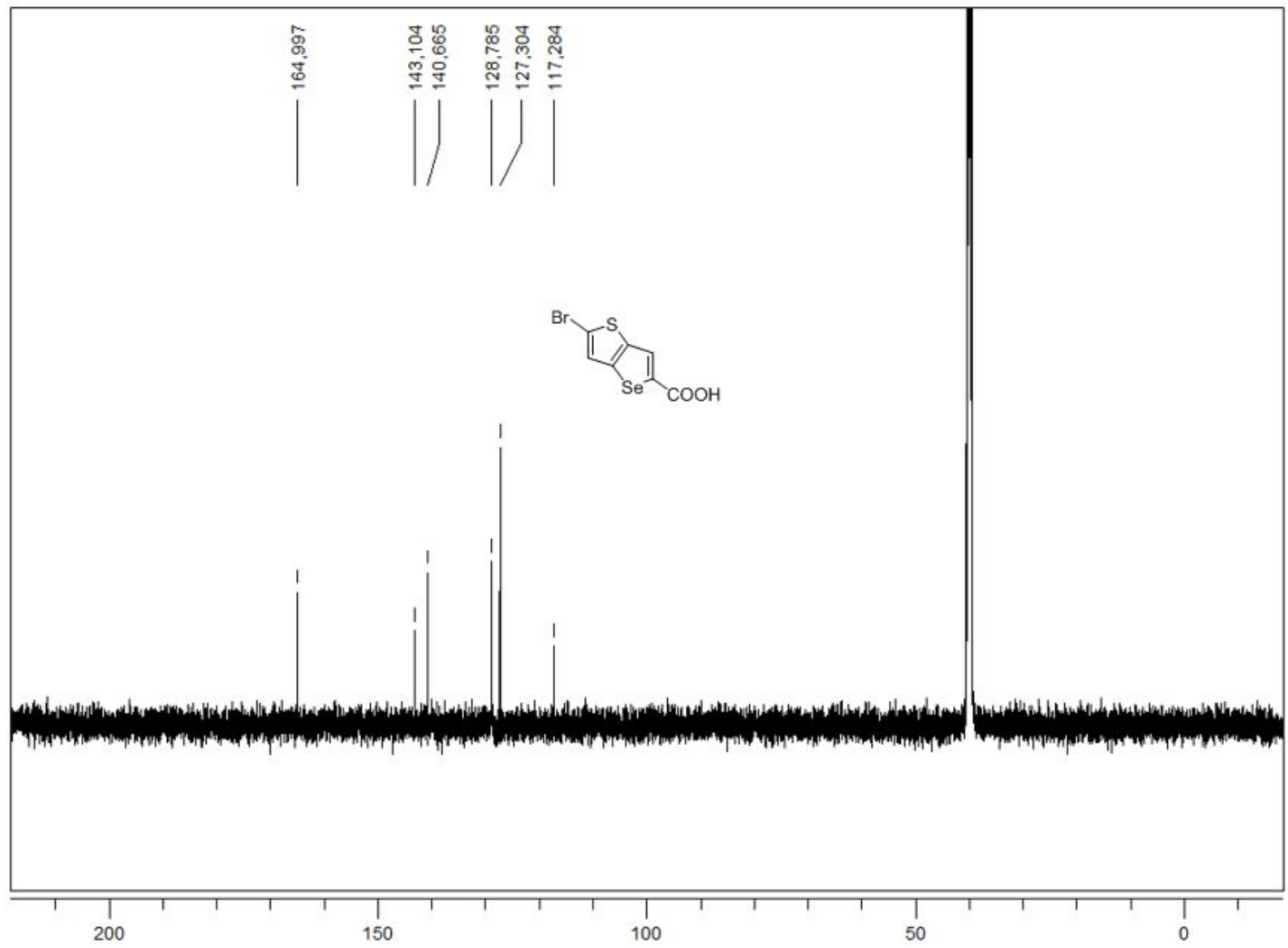

Figure S7. ${ }^{13} \mathrm{C}-\mathrm{NMR}$ of compound (3) 


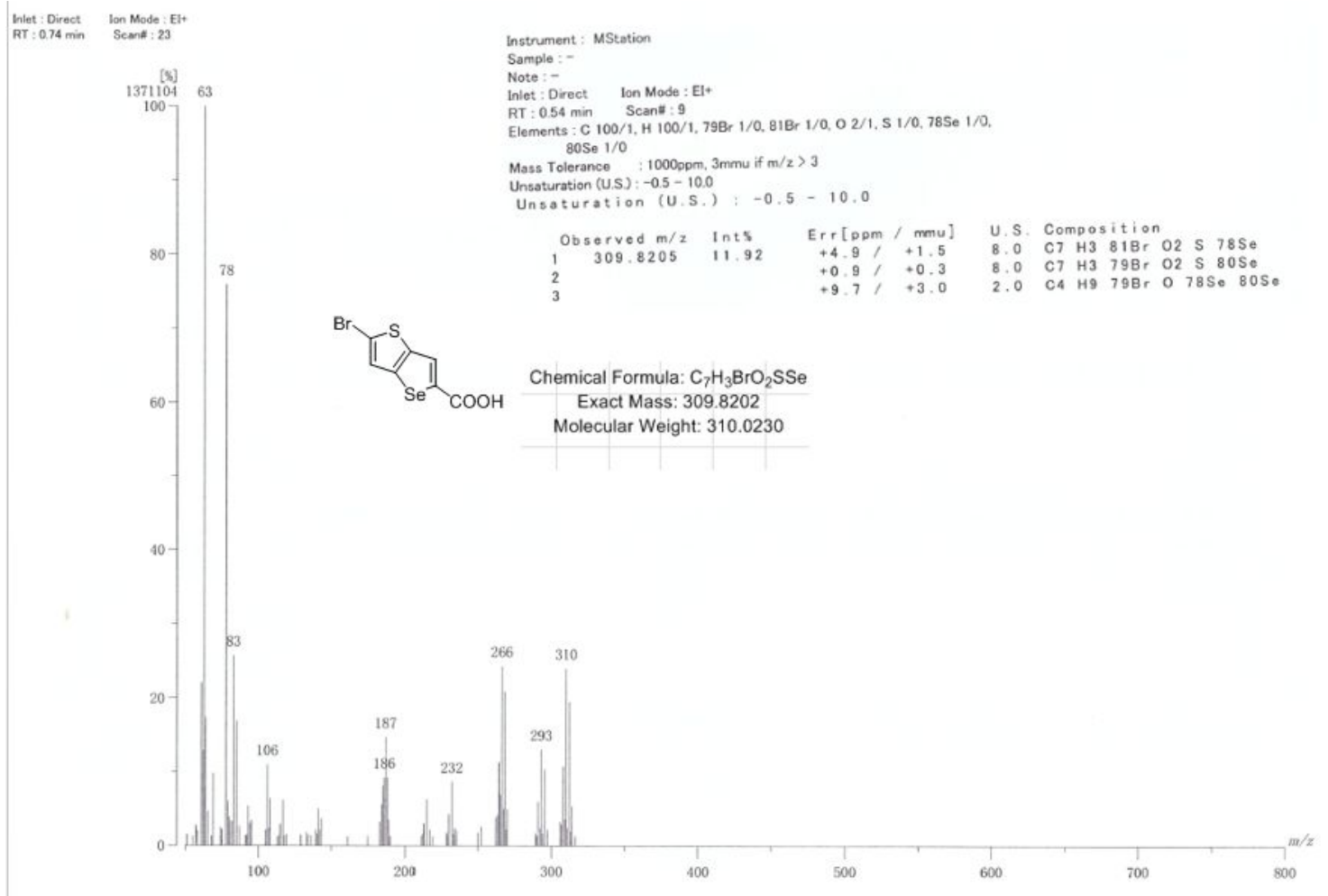

Figure S8. Mass spectrum of compound (3)

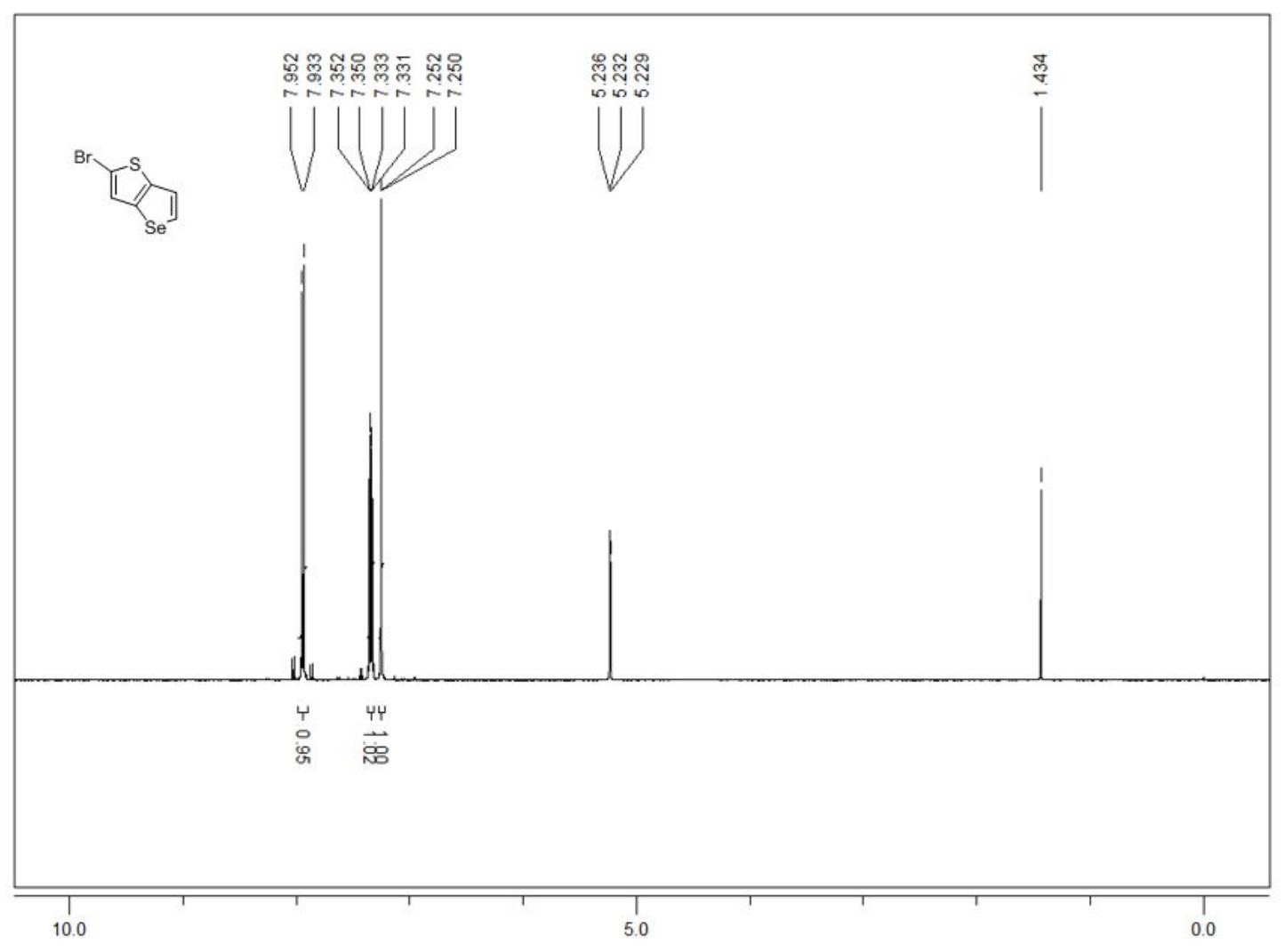

Figure S9. ${ }^{1} \mathrm{H}-\mathrm{NMR}$ of compound (4) 


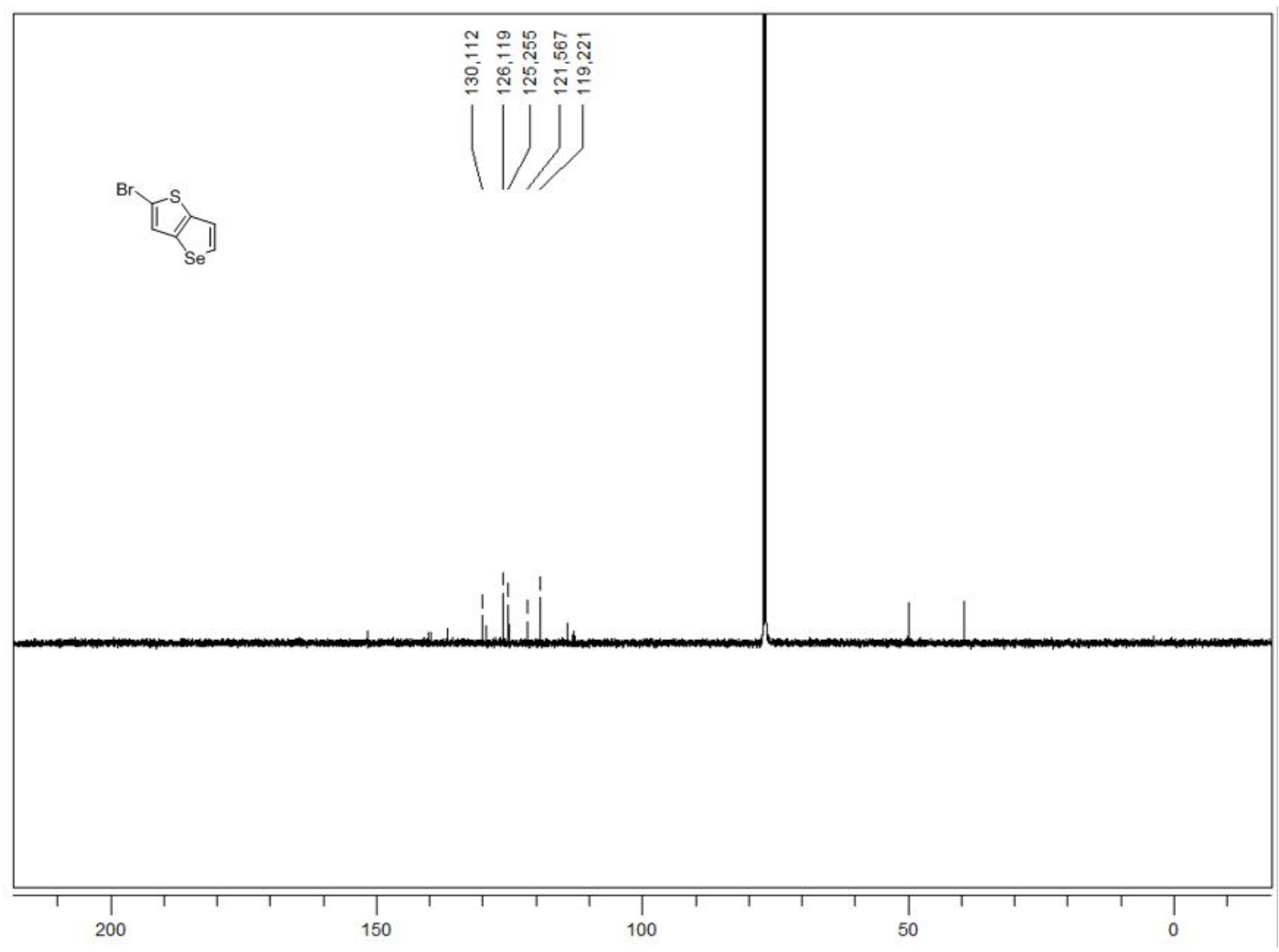

Figure S10. ${ }^{13} \mathrm{C}-\mathrm{NMR}$ of compound (4)

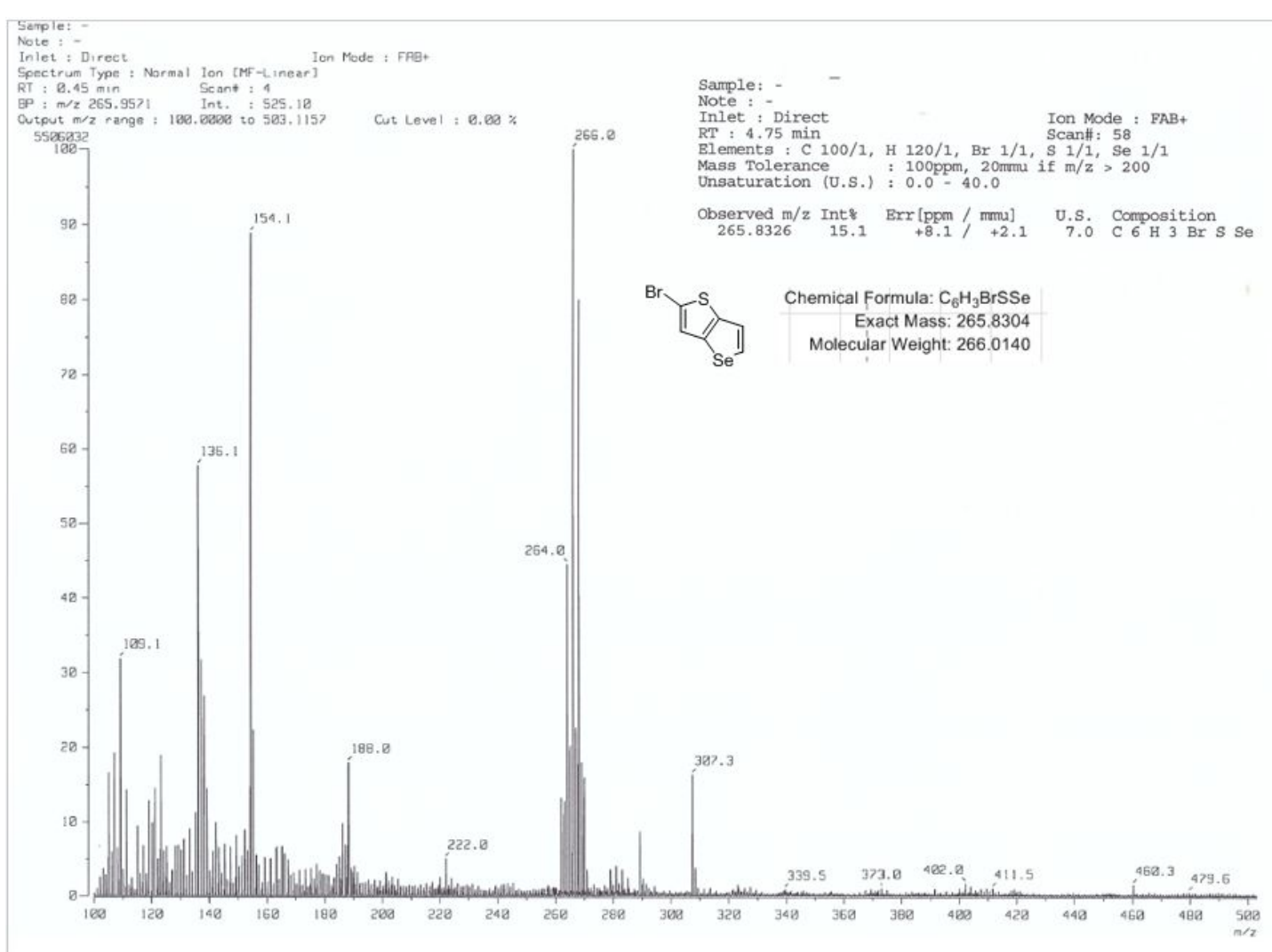

Figure S11. Mass spectrum of compound (4) 


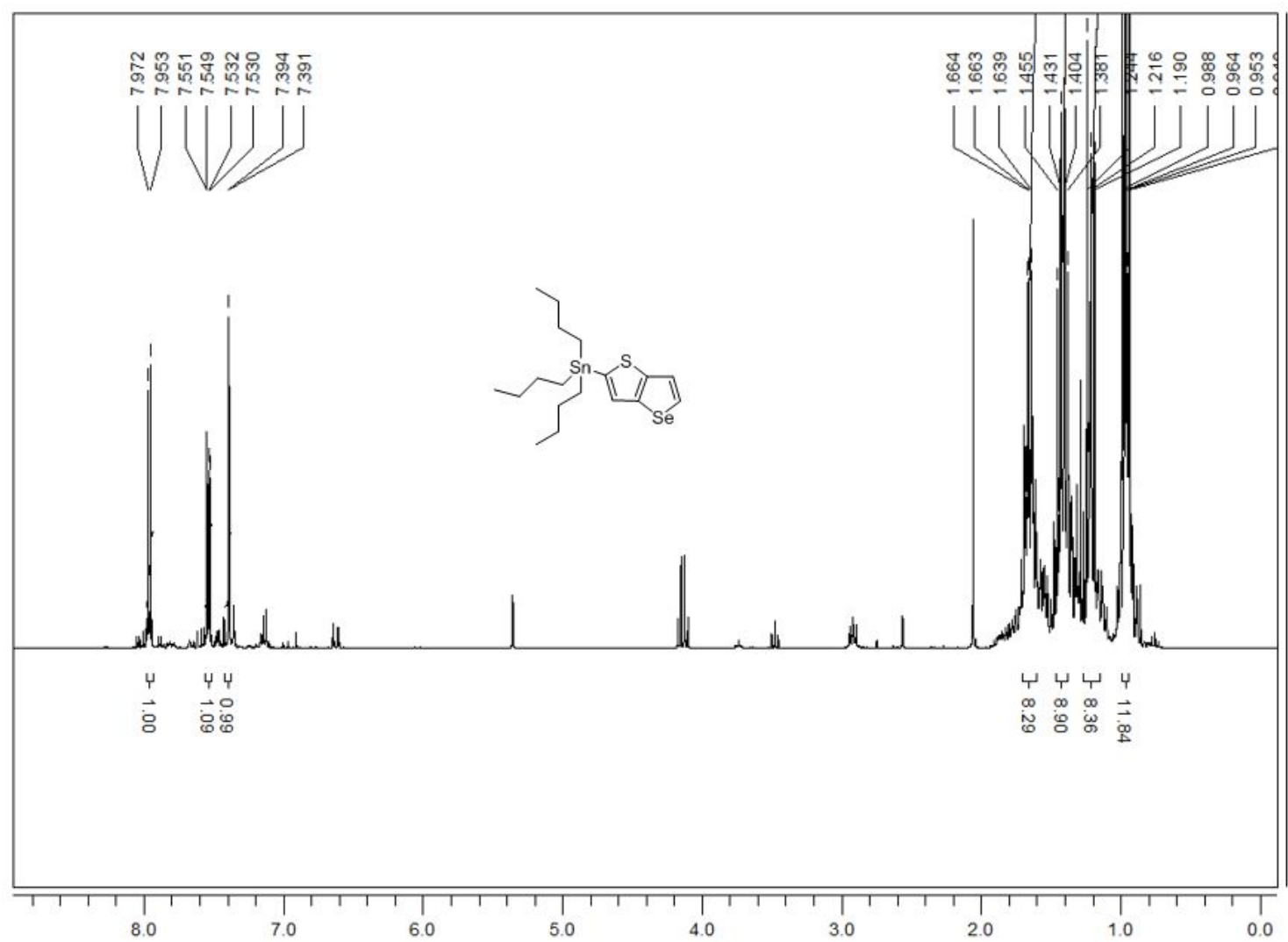

Figure S12. ${ }^{1} \mathrm{H}-\mathrm{NMR}$ of compound (5)

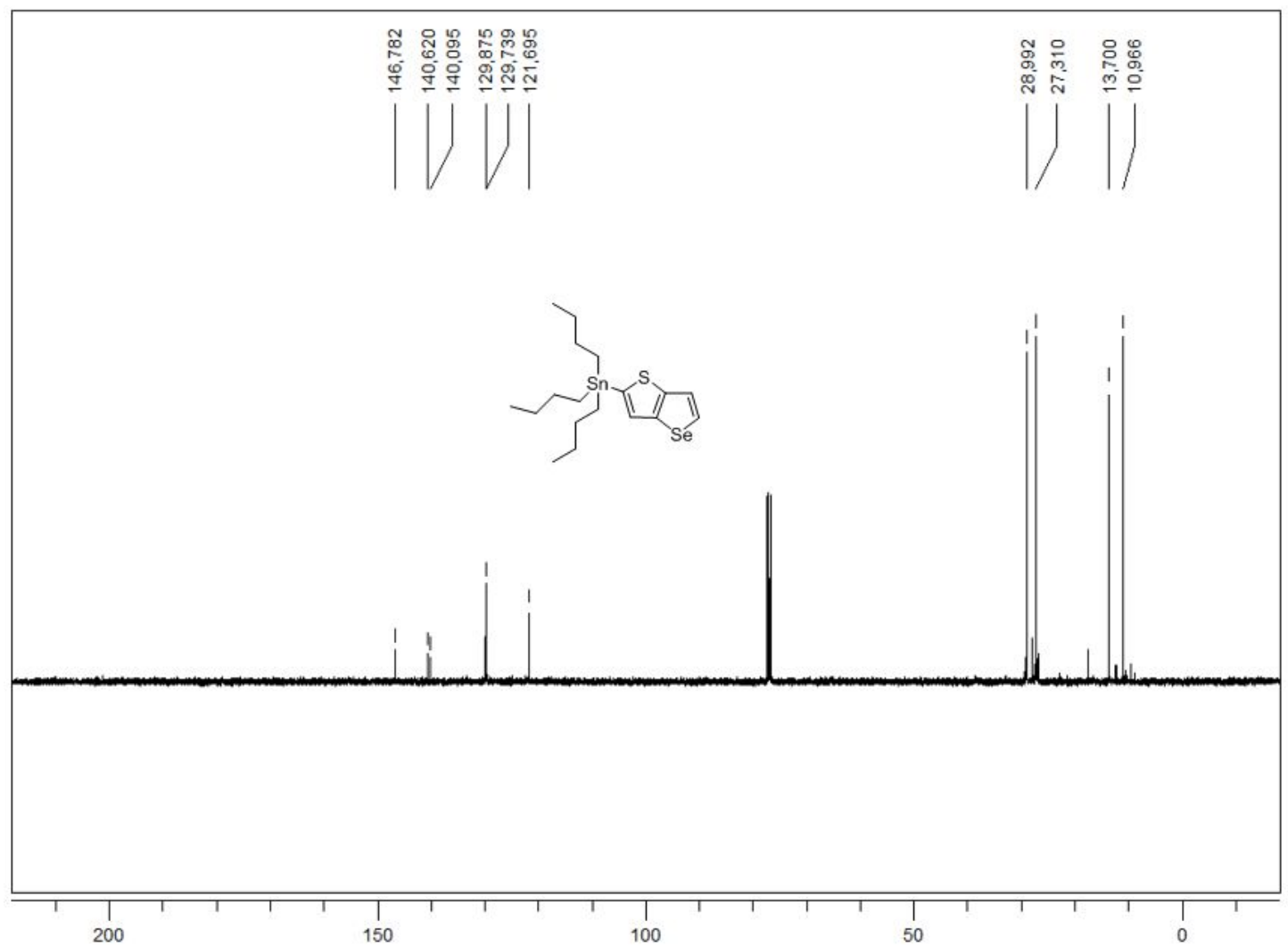

Figure S13. ${ }^{13} \mathrm{C}-\mathrm{NMR}$ of compound (5) 


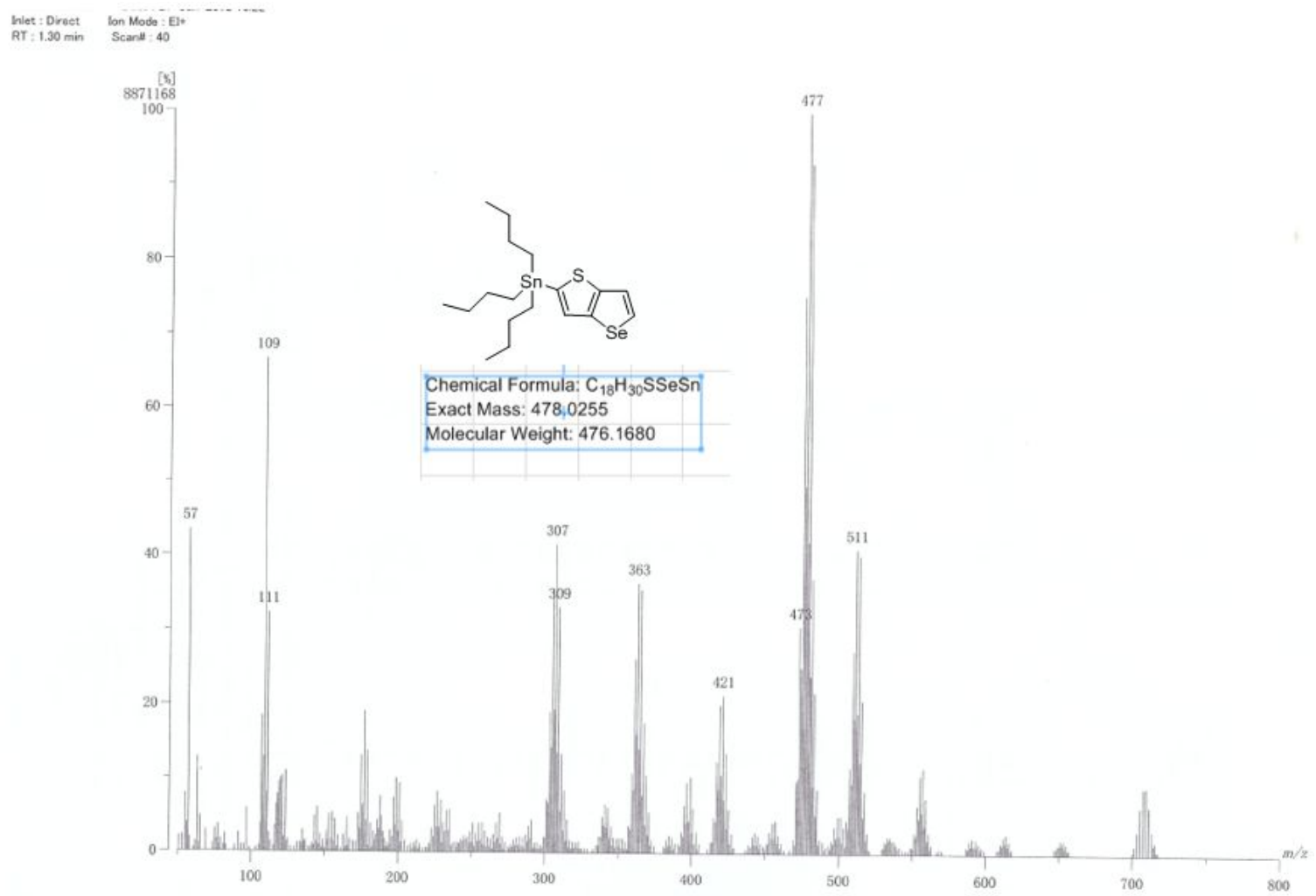

Figure S14. Mass spectrum of compound (5)

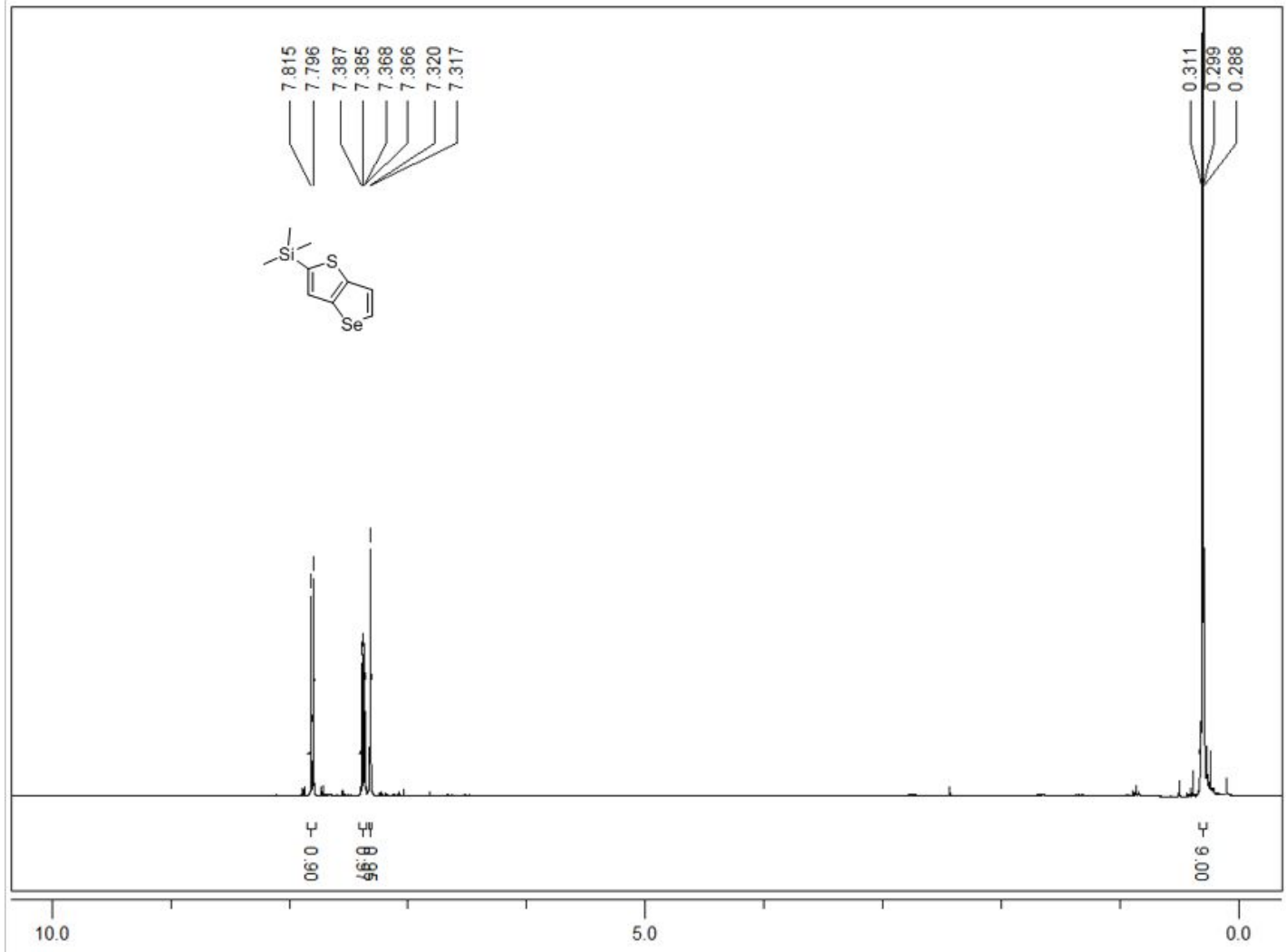

Figure S15. ${ }^{1} \mathrm{H}-\mathrm{NMR}$ of compound (6) 


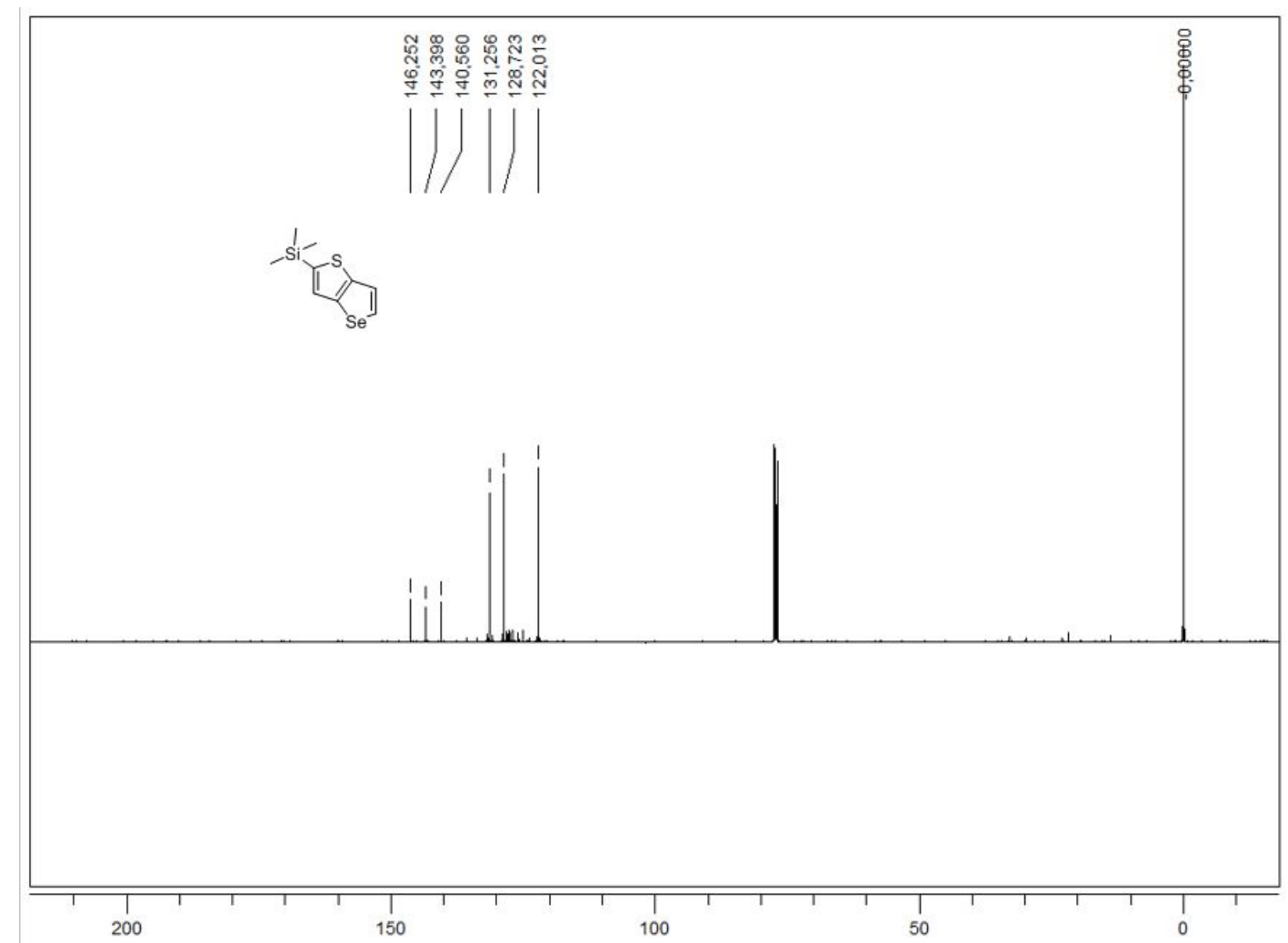

Figure S16. ${ }^{13} \mathrm{C}-\mathrm{NMR}$ of compound (6)

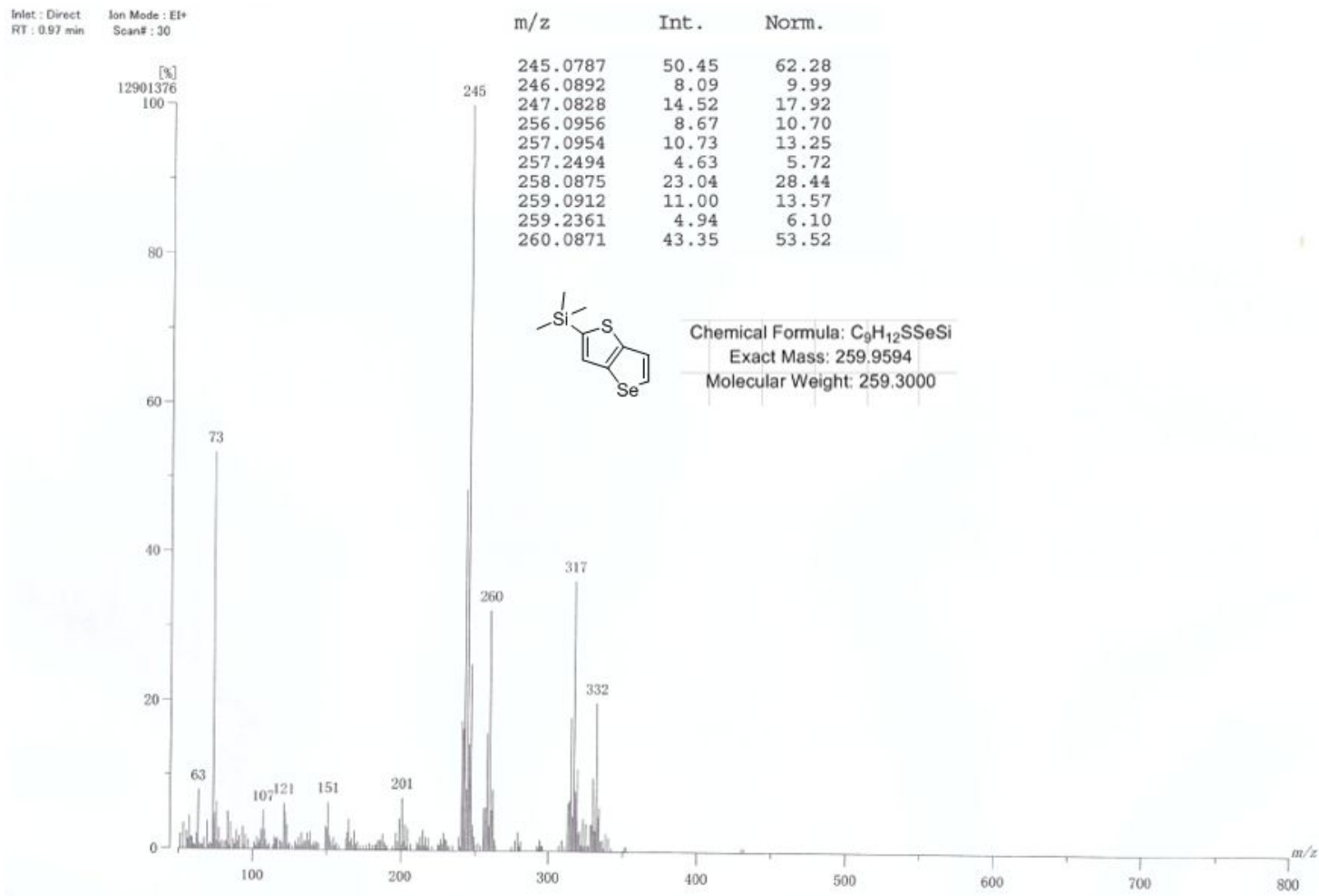

Figure S17. Mass spectrum of compound (6) 


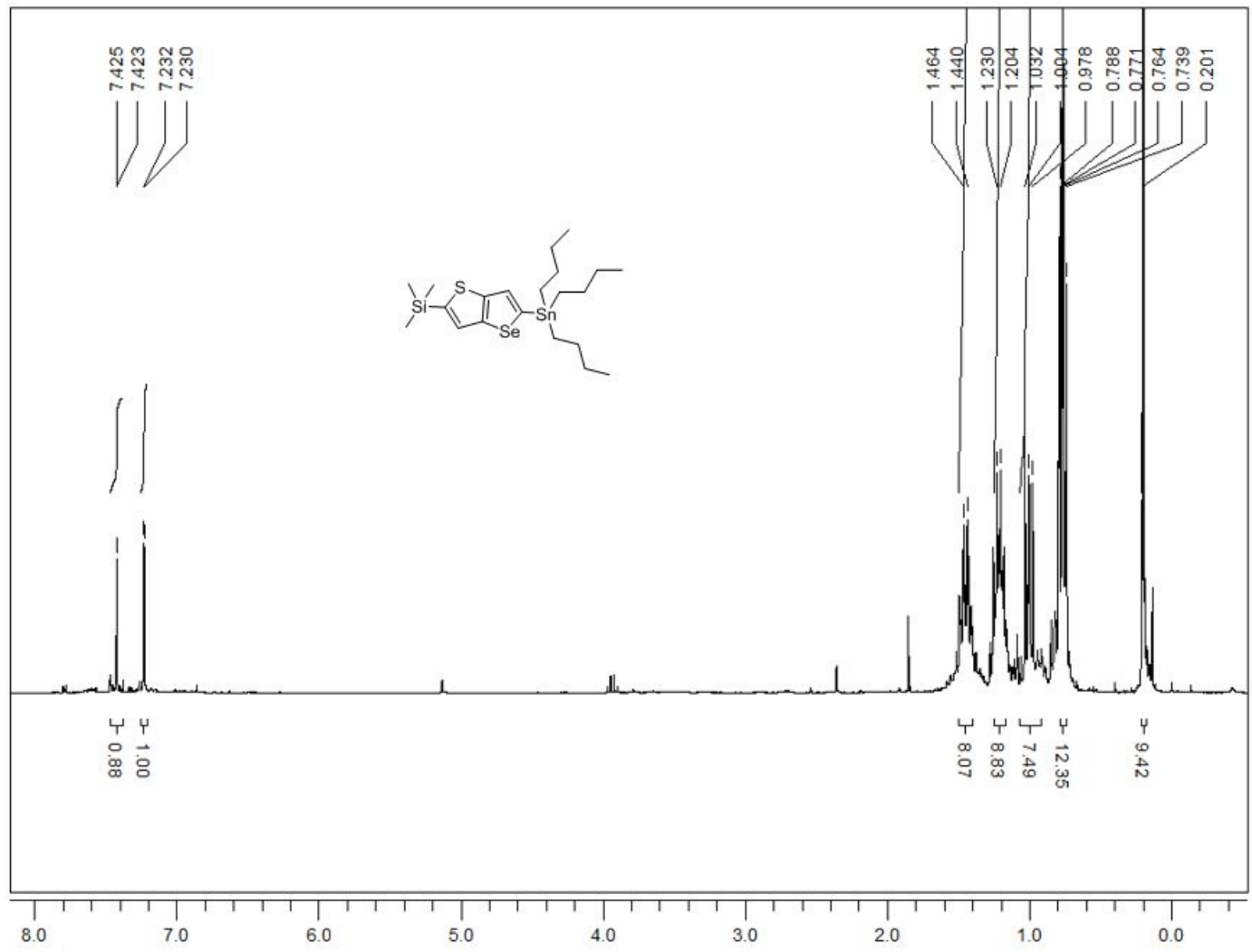

Figure S18. ${ }^{1} \mathrm{H}-\mathrm{NMR}$ of compound (7)

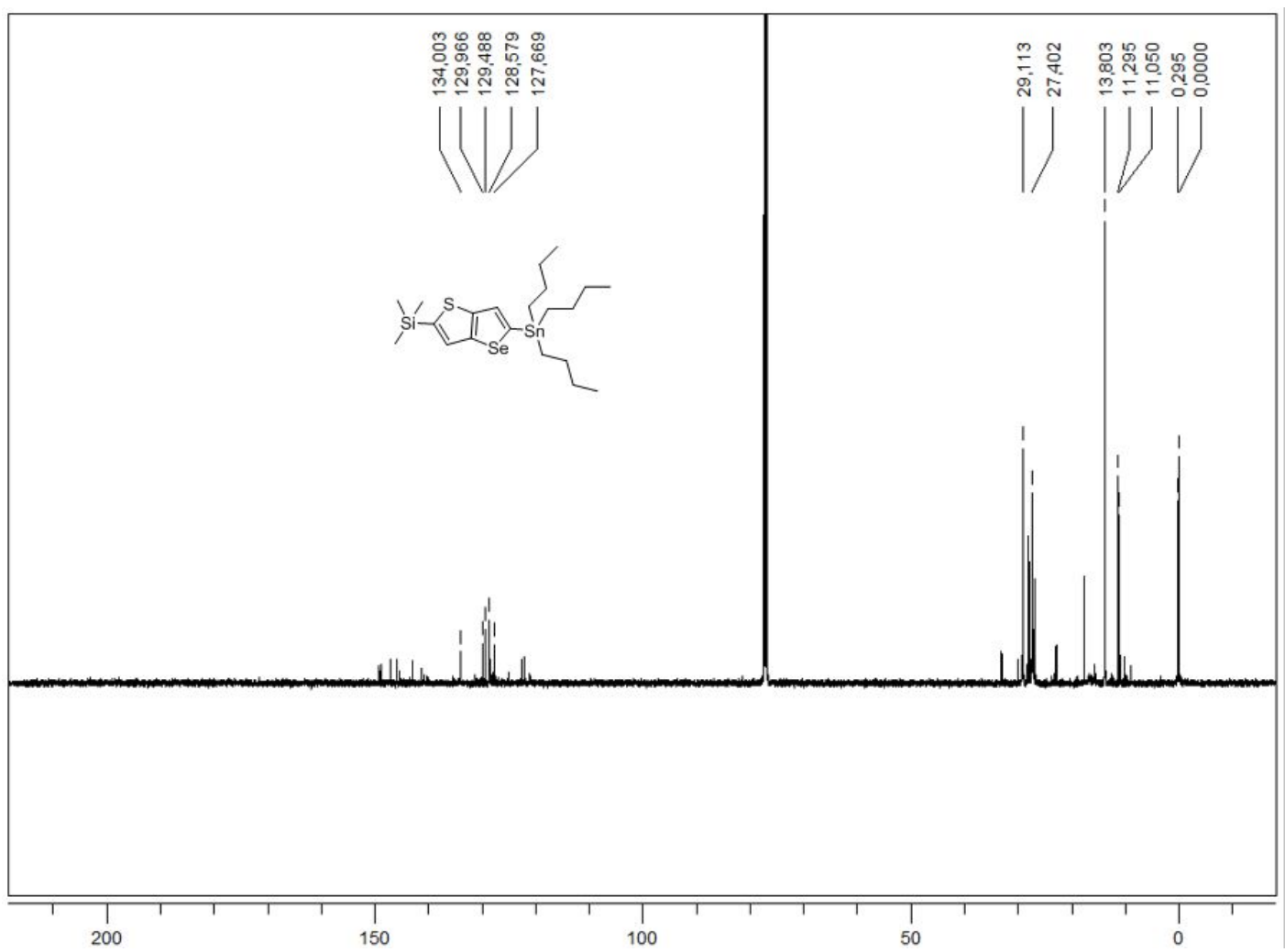

Figure S19. ${ }^{13} \mathrm{C}-\mathrm{NMR}$ of compound (7) 


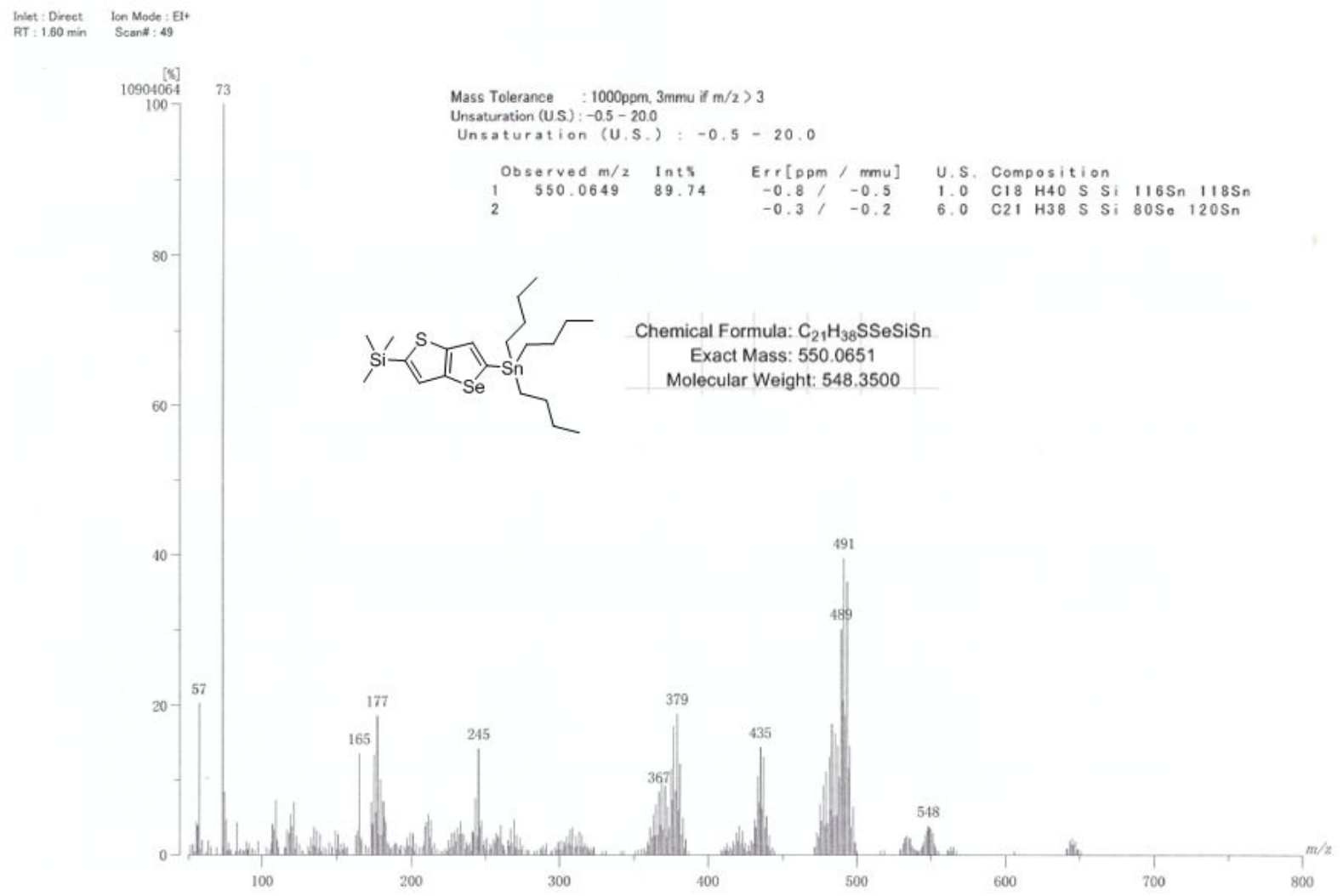

Figure S20. Mass spectrum of compound (7)

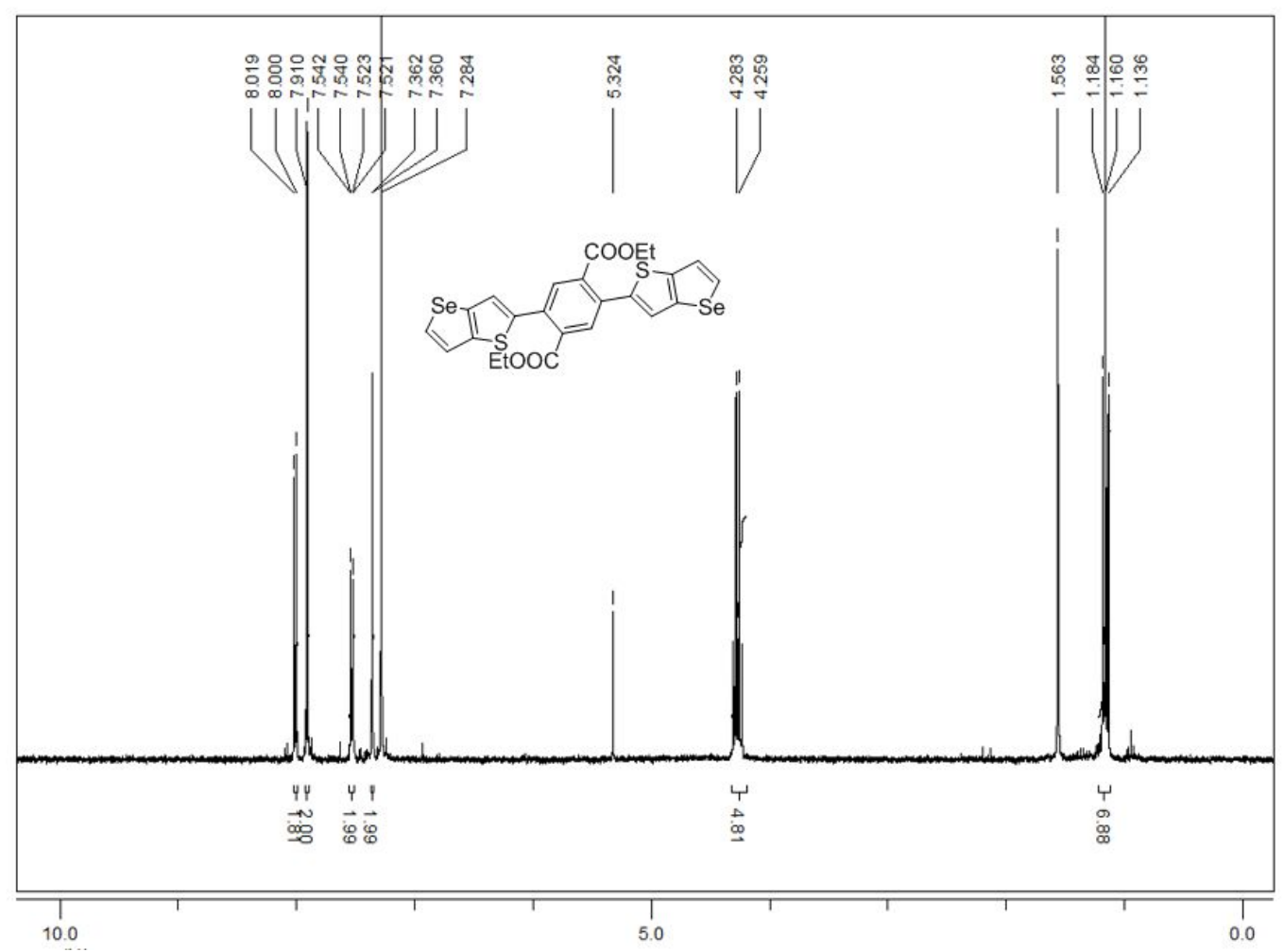

Figure S21. ${ }^{1} \mathrm{H}-\mathrm{NMR}$ of compound (8) 


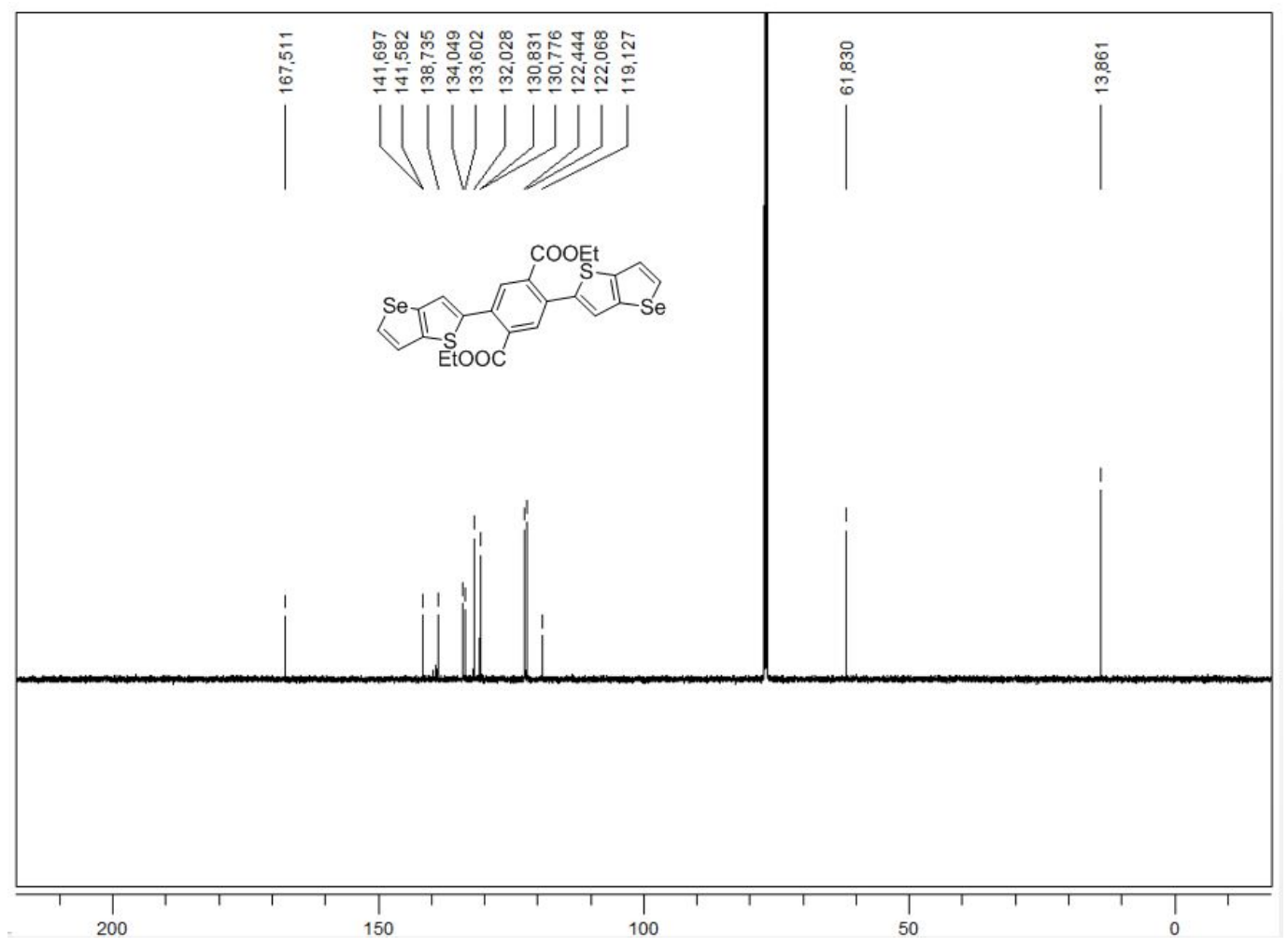

Figure S22. ${ }^{13} \mathrm{C}$-NMR of compound (8)

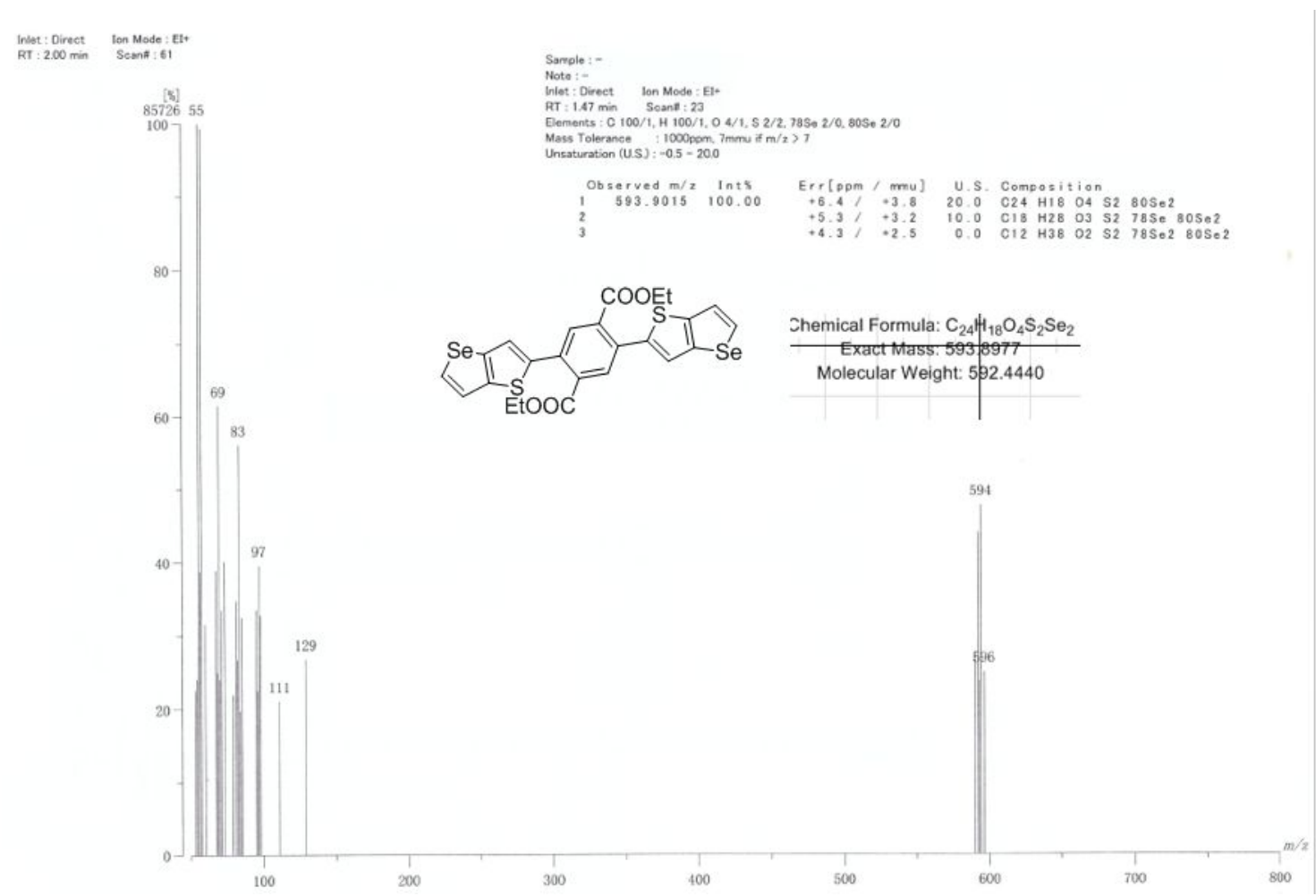

Figure S23. Mass spectrum of compound (8) 


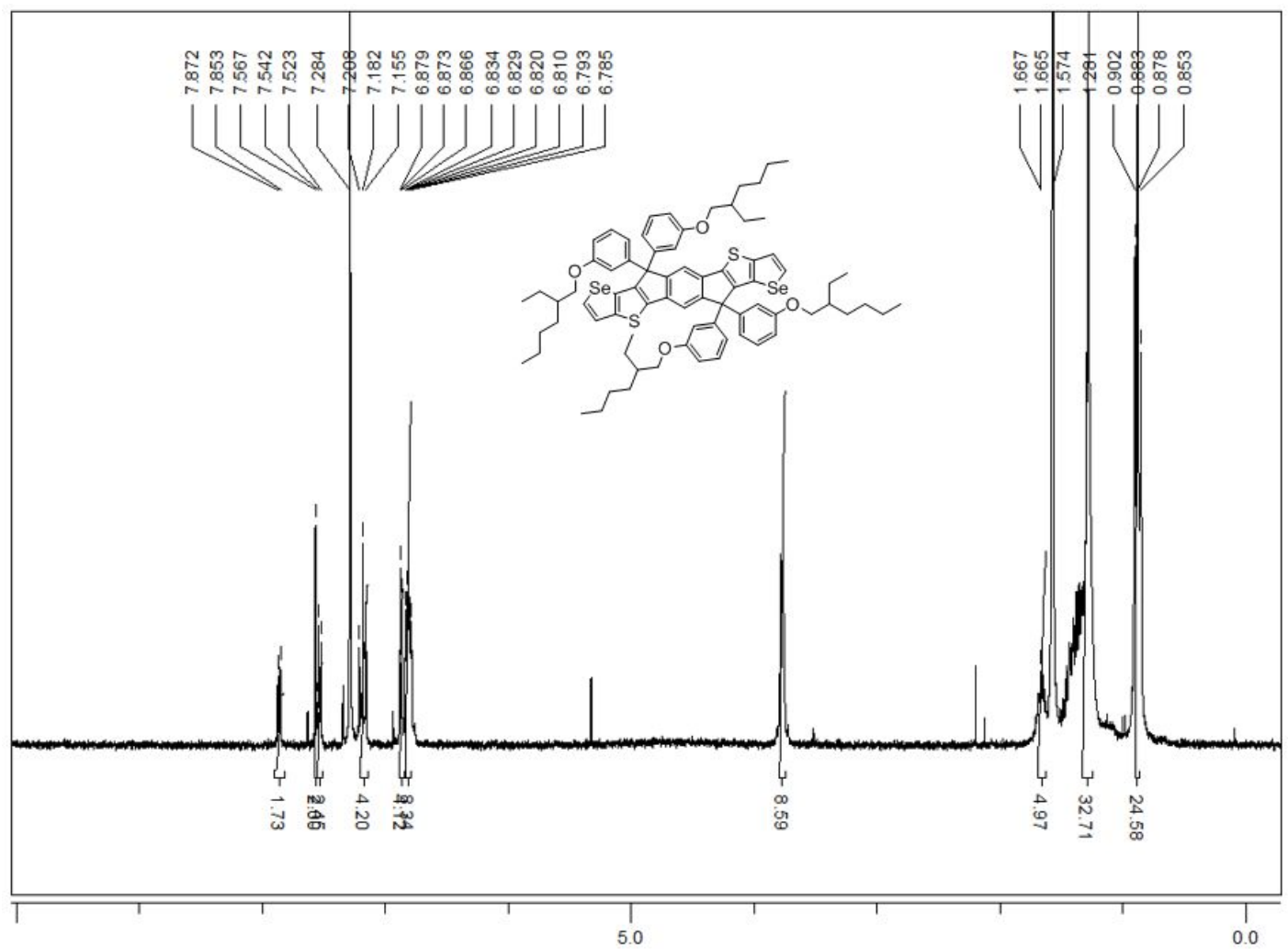

Figure S24. ${ }^{1} \mathrm{H}-\mathrm{NMR}$ of compound (9)

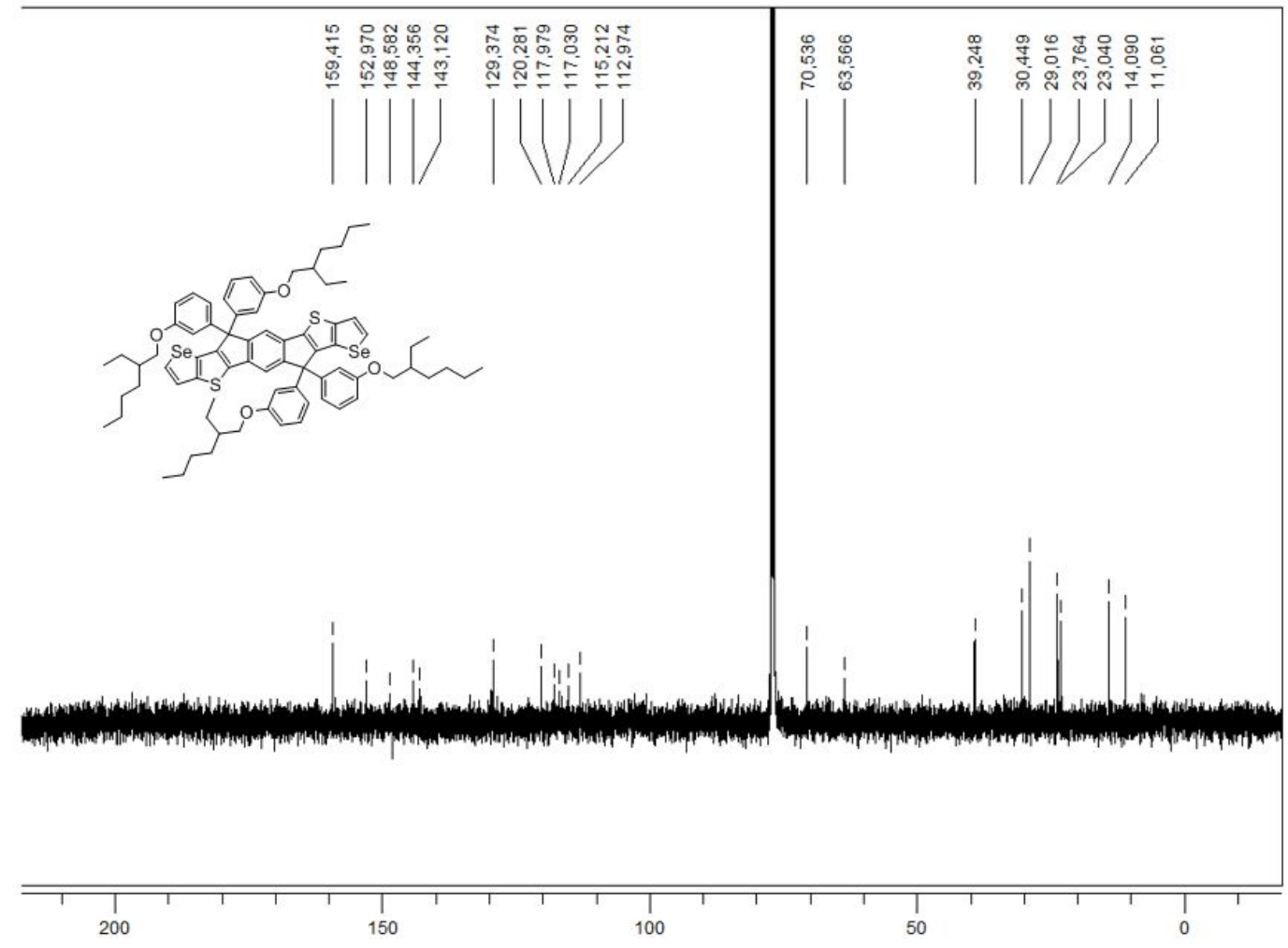

Figure S25. ${ }^{13} \mathrm{C}$-NMR of compound (9) 


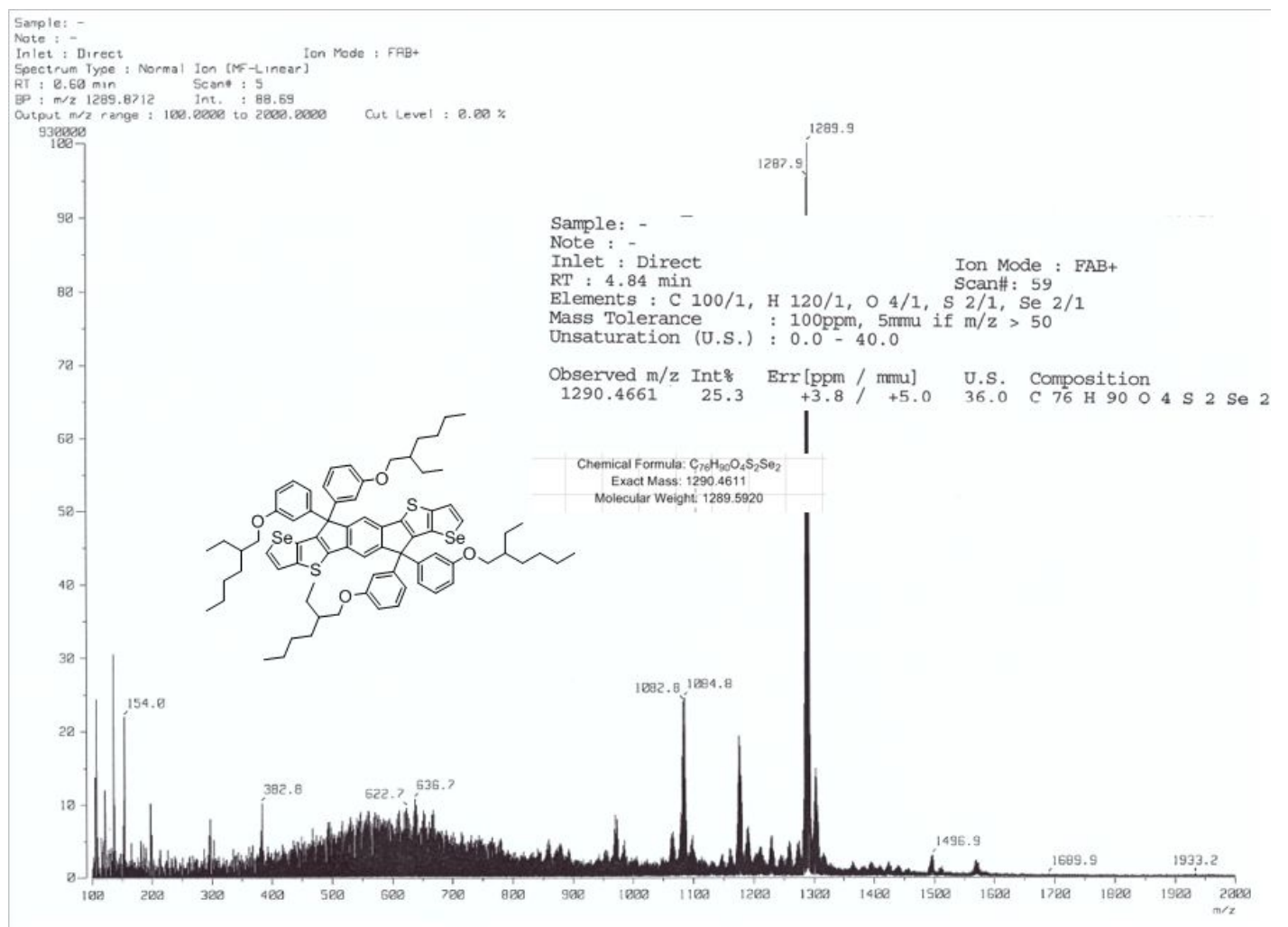

Figure S26. Mass spectrum of compound (9)

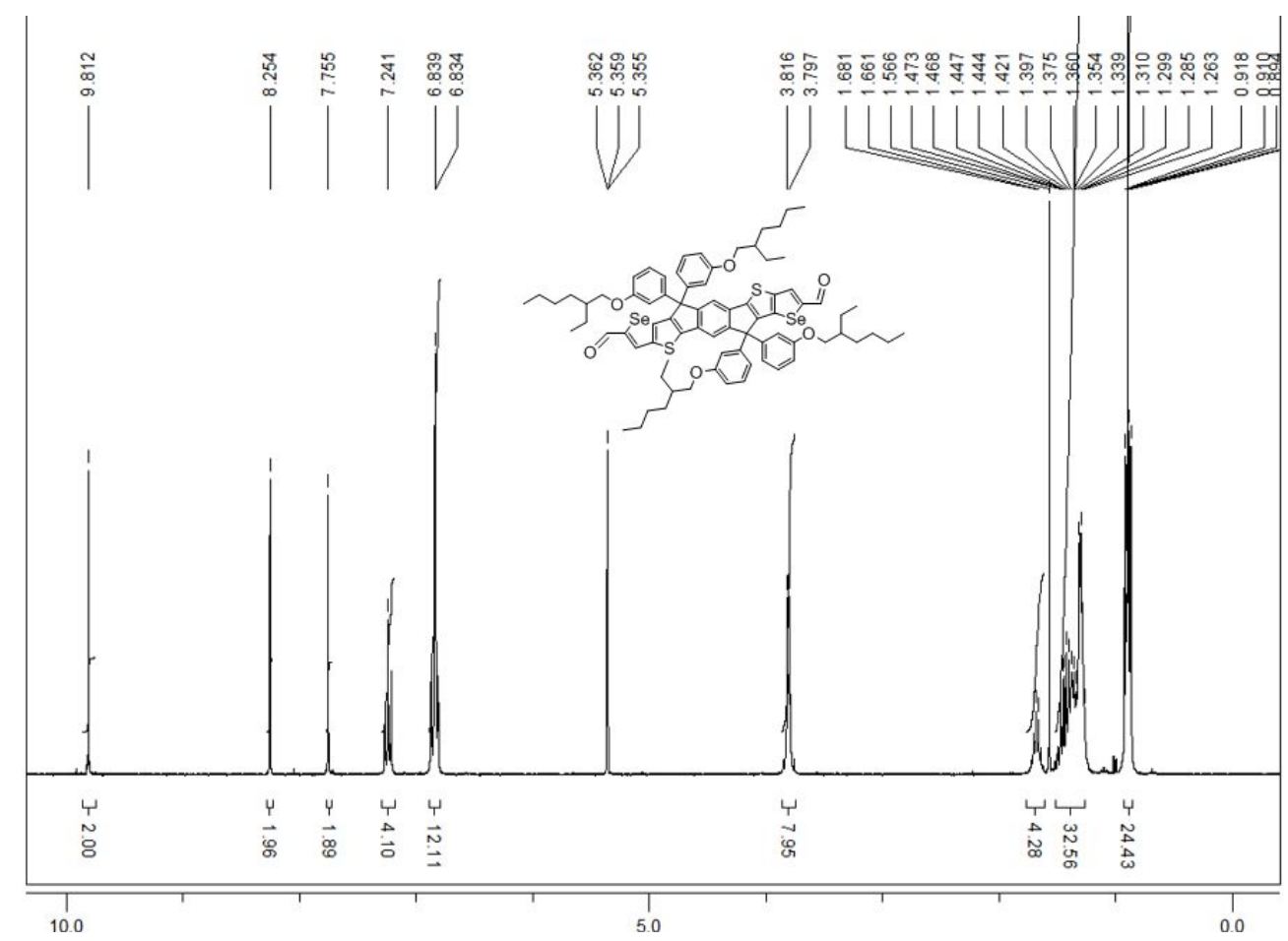

Figure S27. ${ }^{1} \mathrm{H}-\mathrm{NMR}$ of compound (10) 


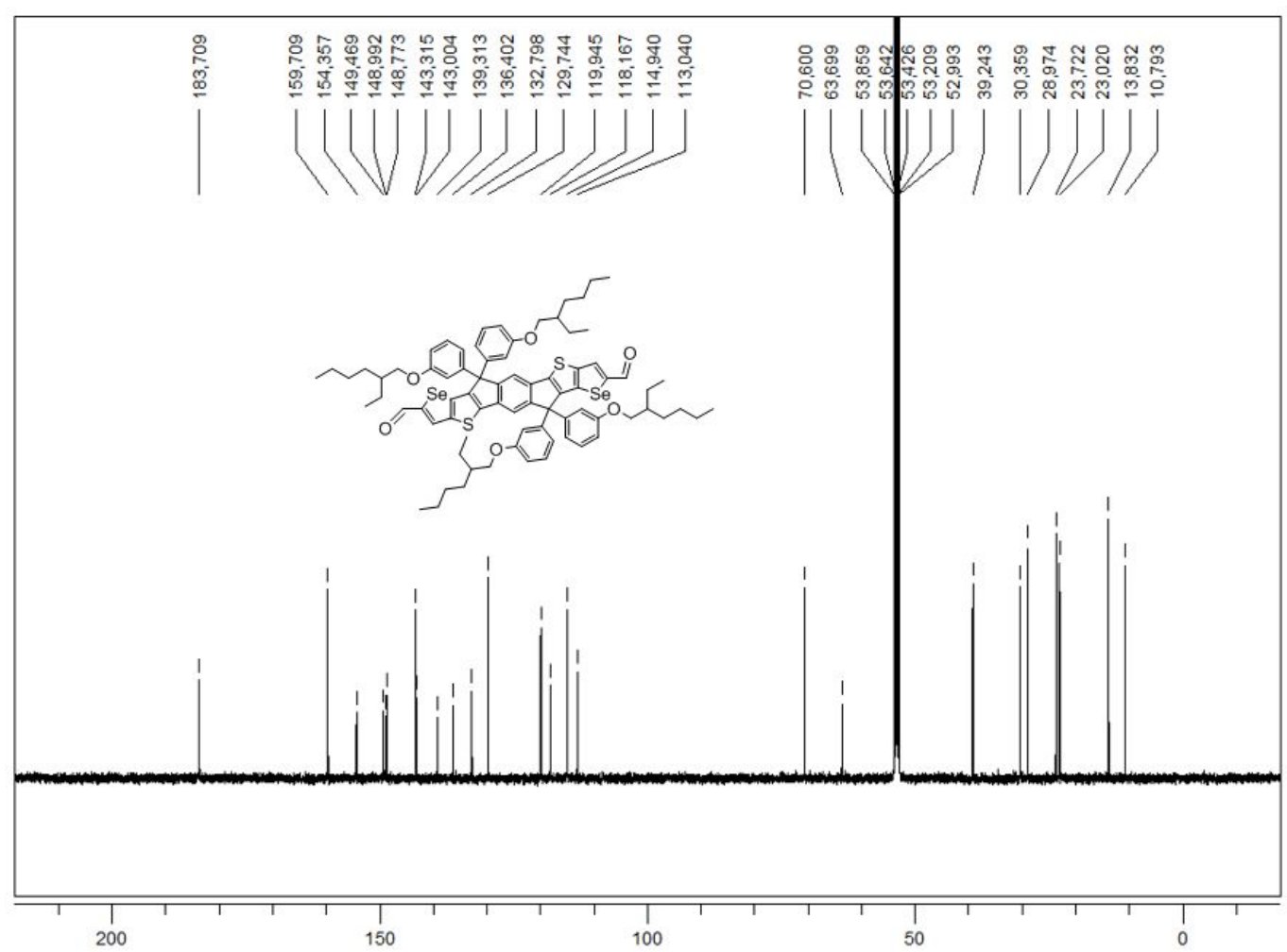

Figure S28. ${ }^{13} \mathrm{C}$-NMR of compound (10)

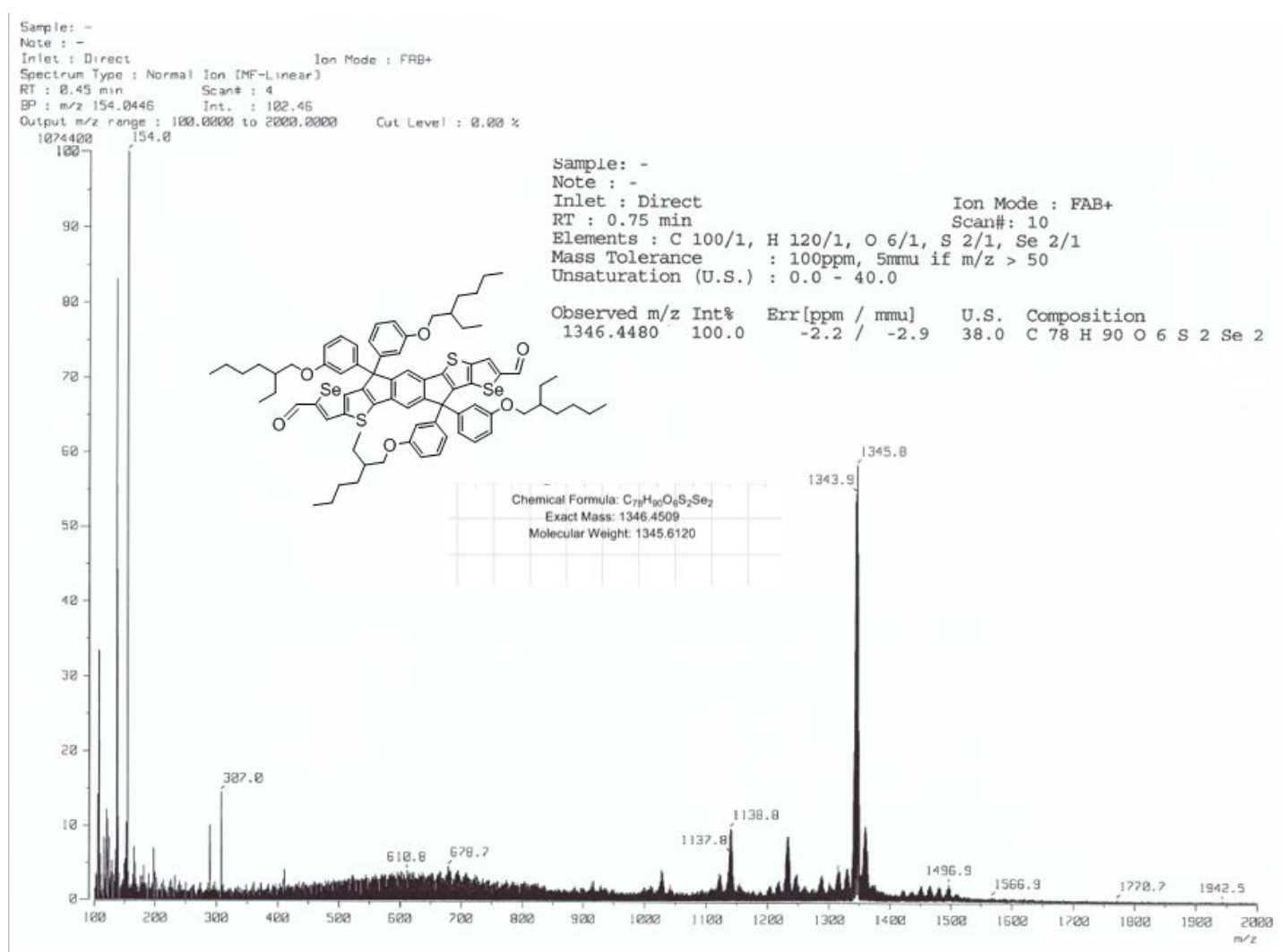

Figure S29. Mass spectrum of compound (10) 


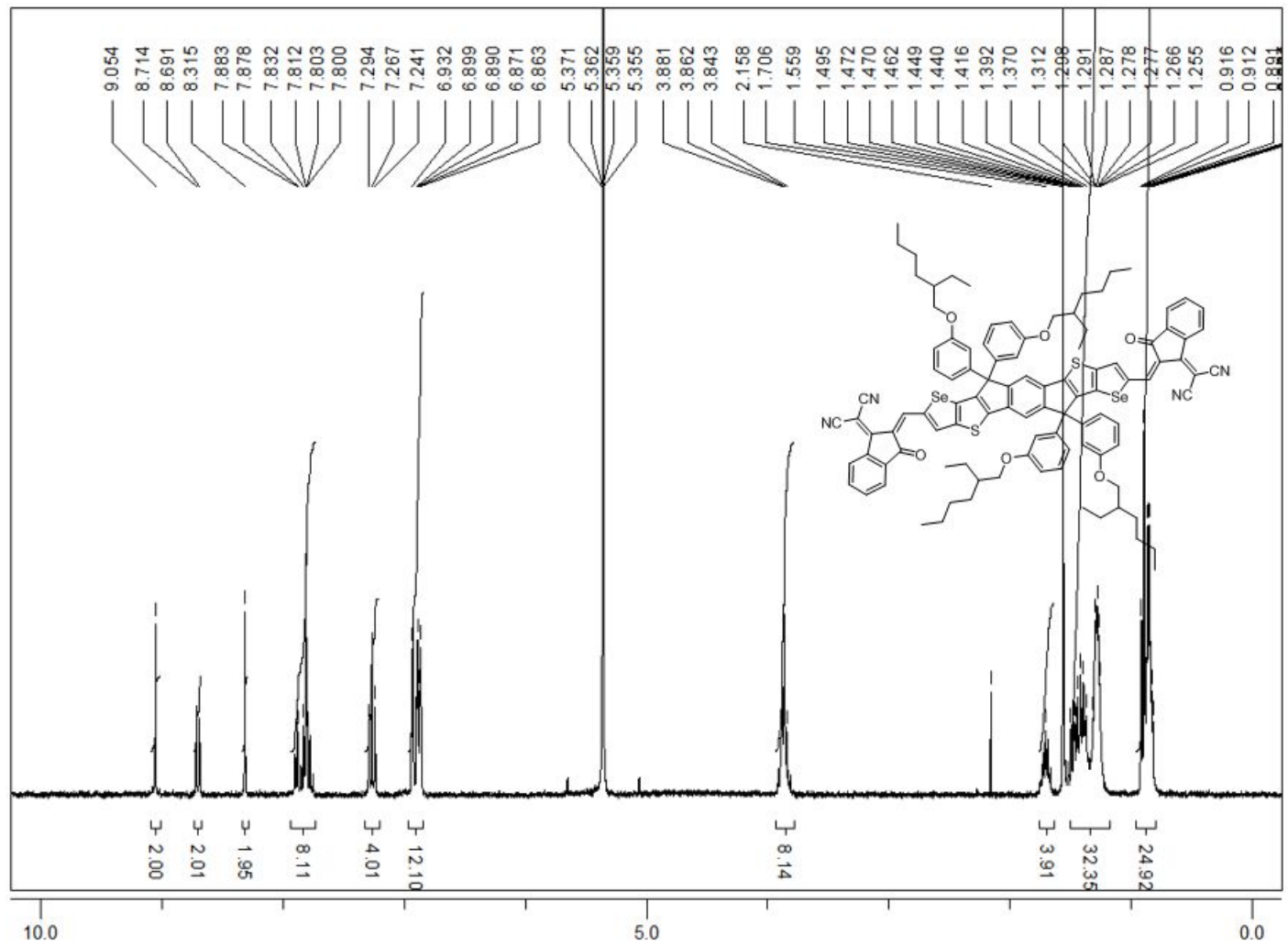

Figure S30. ${ }^{1} \mathrm{H}-\mathrm{NMR}$ of compound (SeOut)

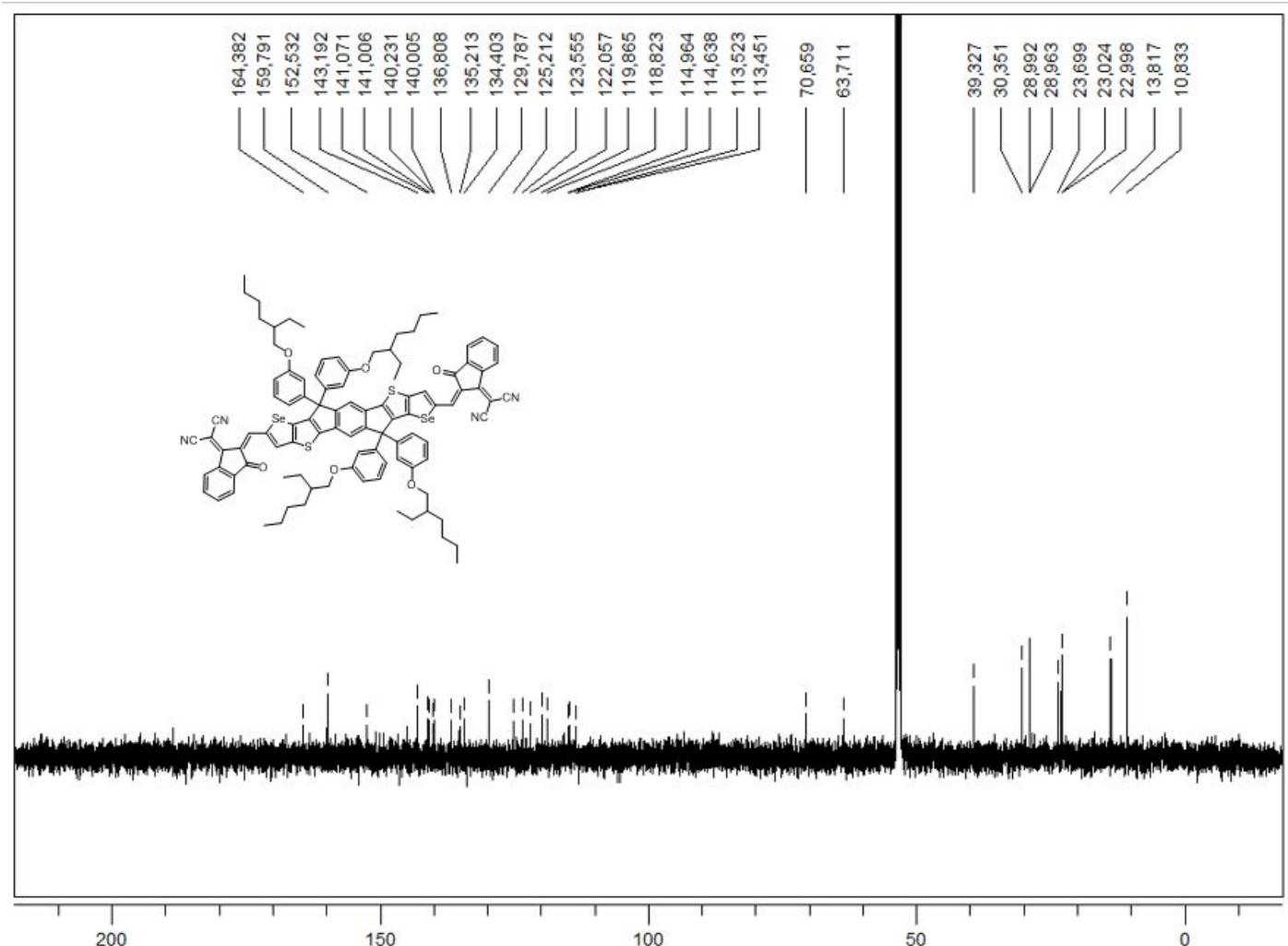

Figure S31. ${ }^{13} \mathrm{C}-\mathrm{NMR}$ of compound (SeOut) 


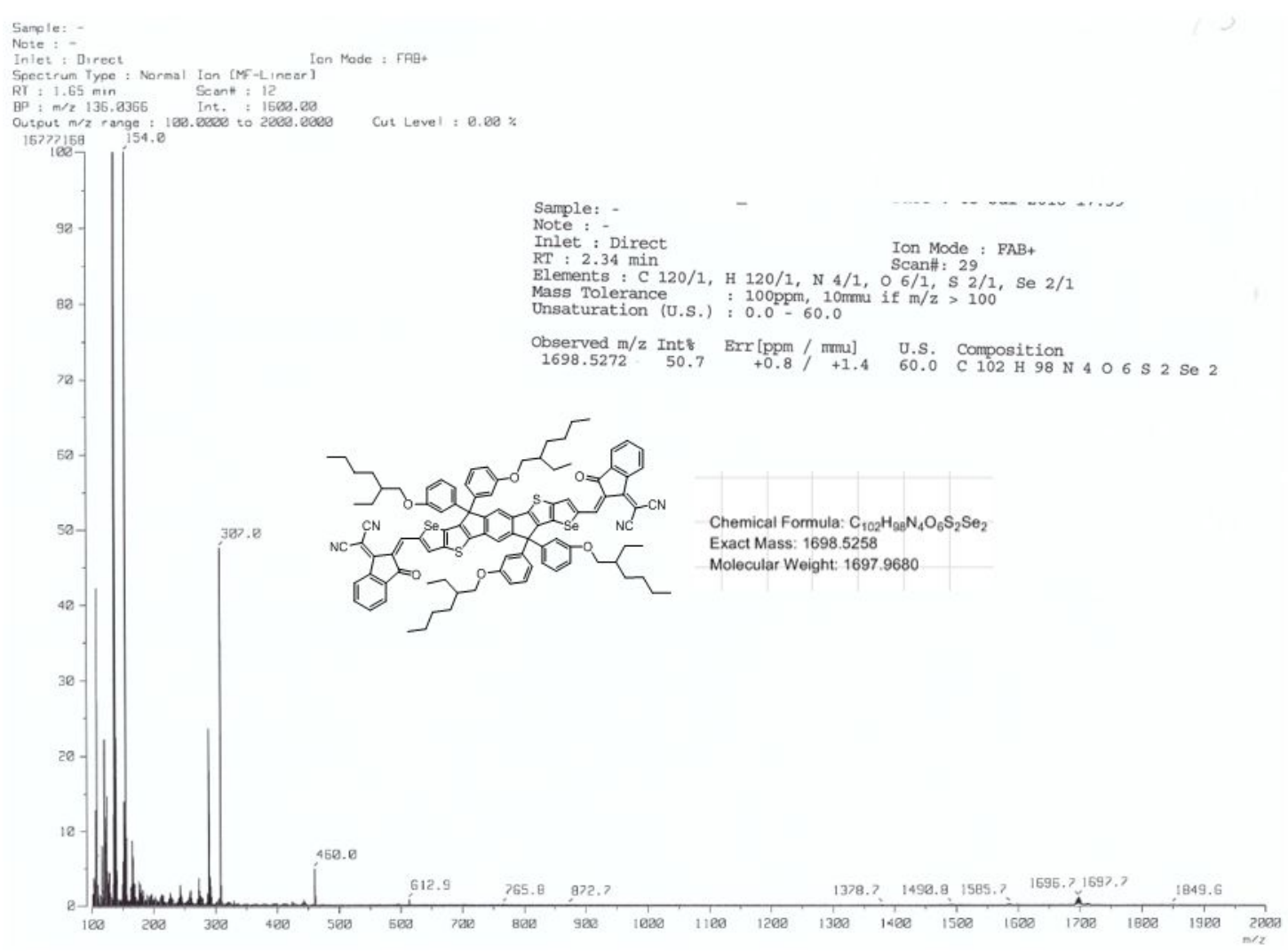

Figure S32. Mass spectrum of compound (SeOut)

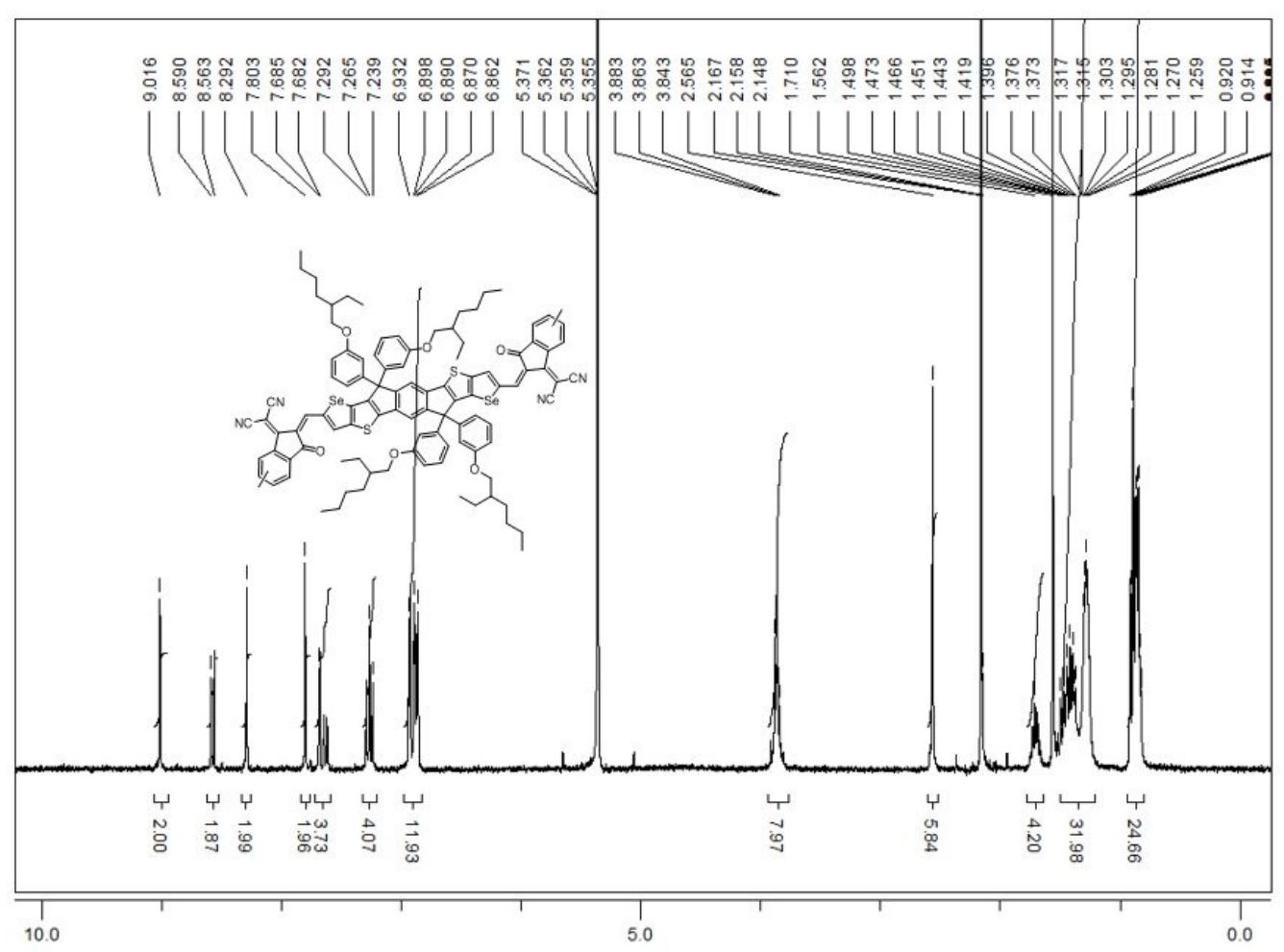

Figure S33. ${ }^{1} \mathrm{H}-\mathrm{NMR}$ of compound (SeOutMe) 


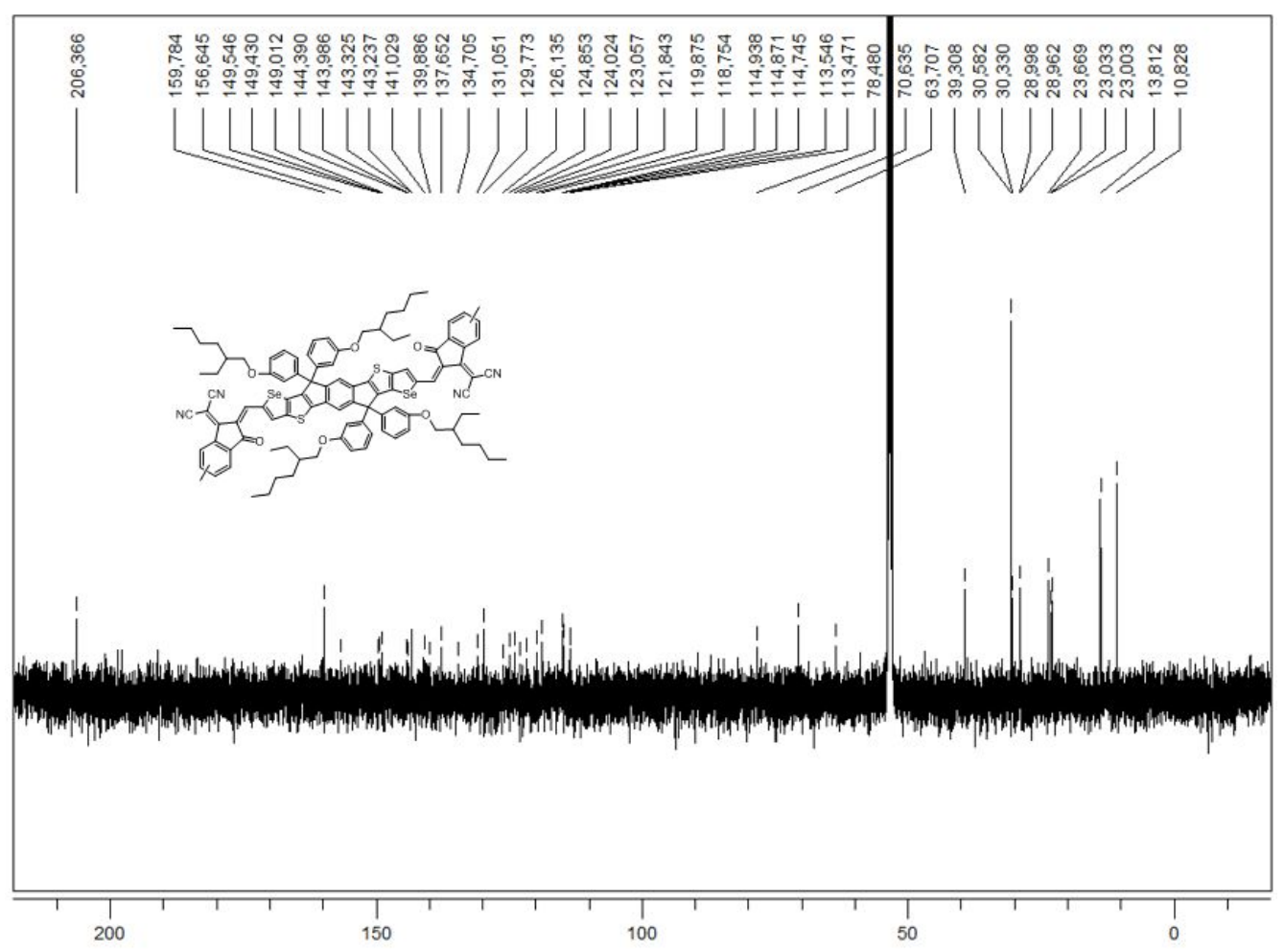

Figure S34. ${ }^{13} \mathrm{C}-\mathrm{NMR}$ of compound (SeOutMe)

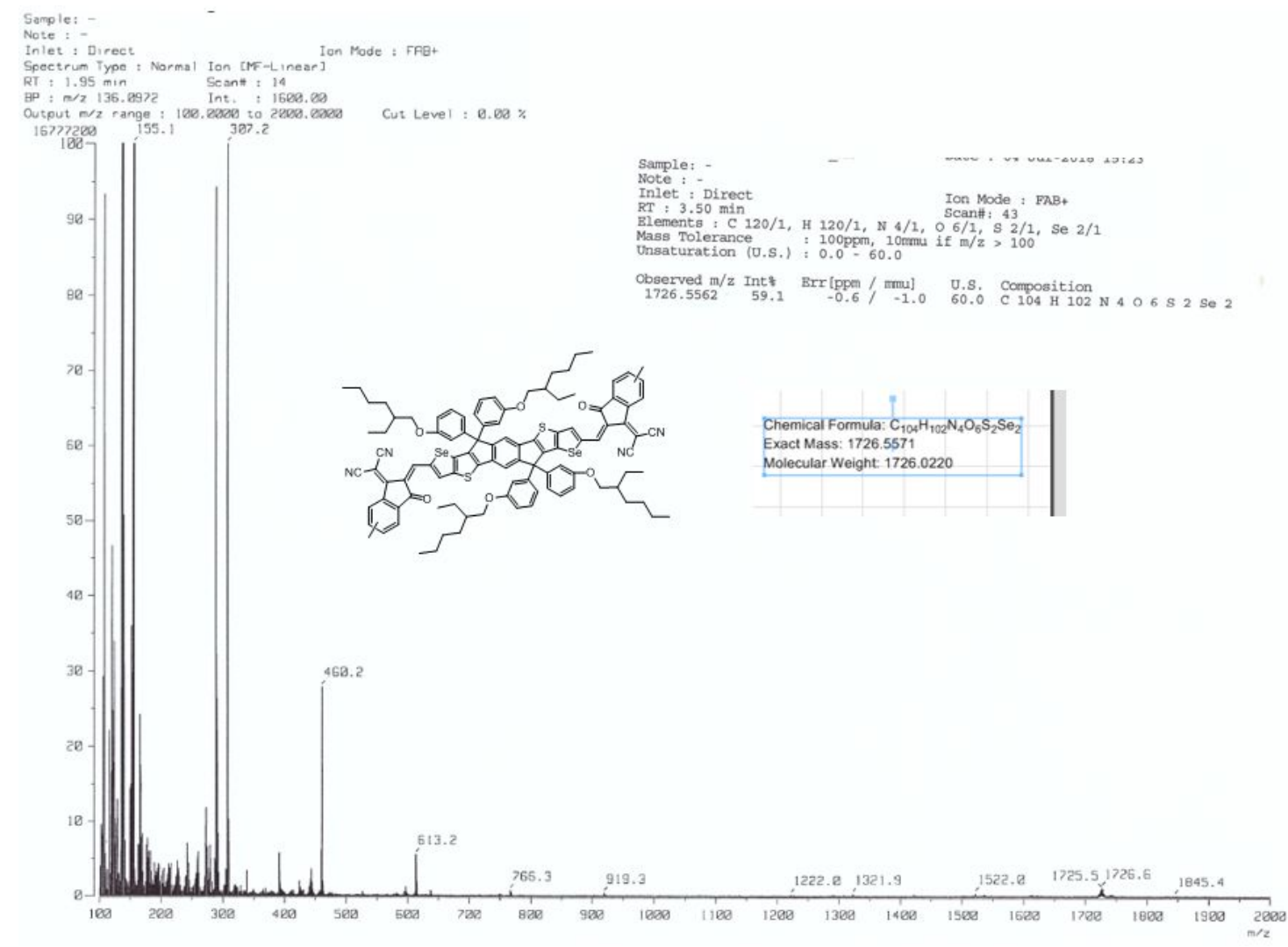

Figure S35. Mass spectrum of compound (SeOutMe) 


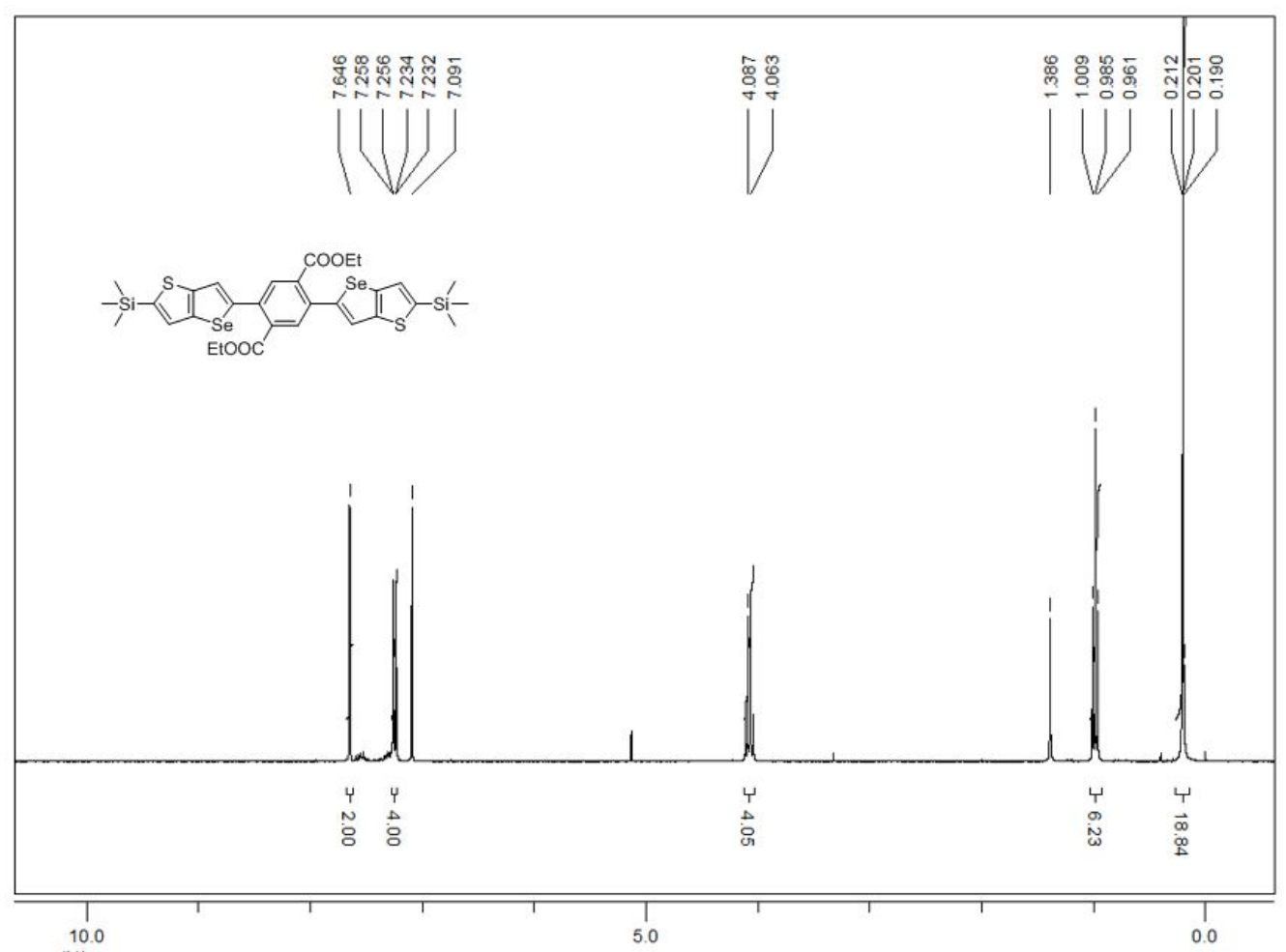

Figure S36. ${ }^{1} \mathrm{H}-\mathrm{NMR}$ of compound (11)

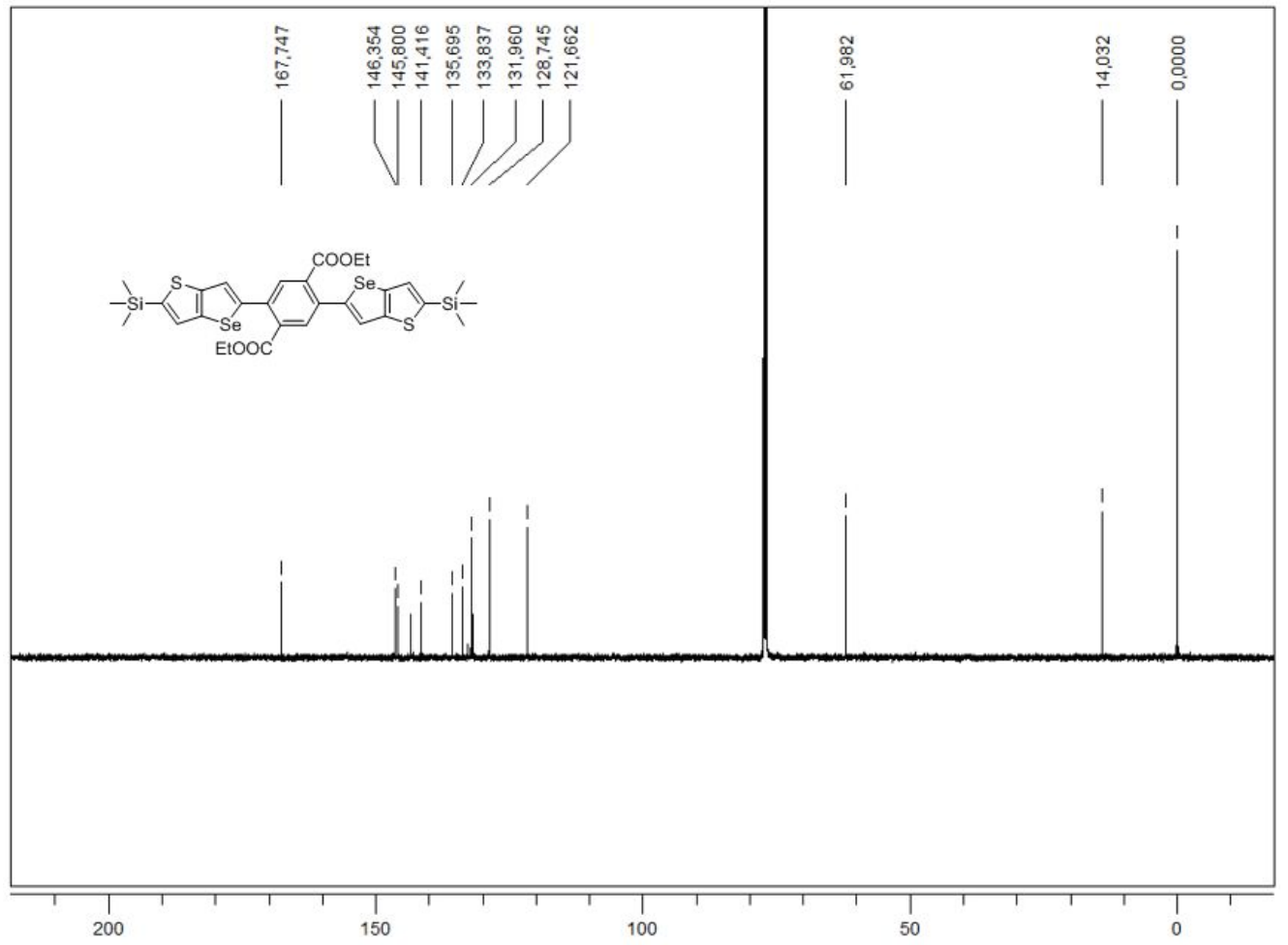

Figure S37. ${ }^{13} \mathrm{C}-\mathrm{NMR}$ of compound (11) 


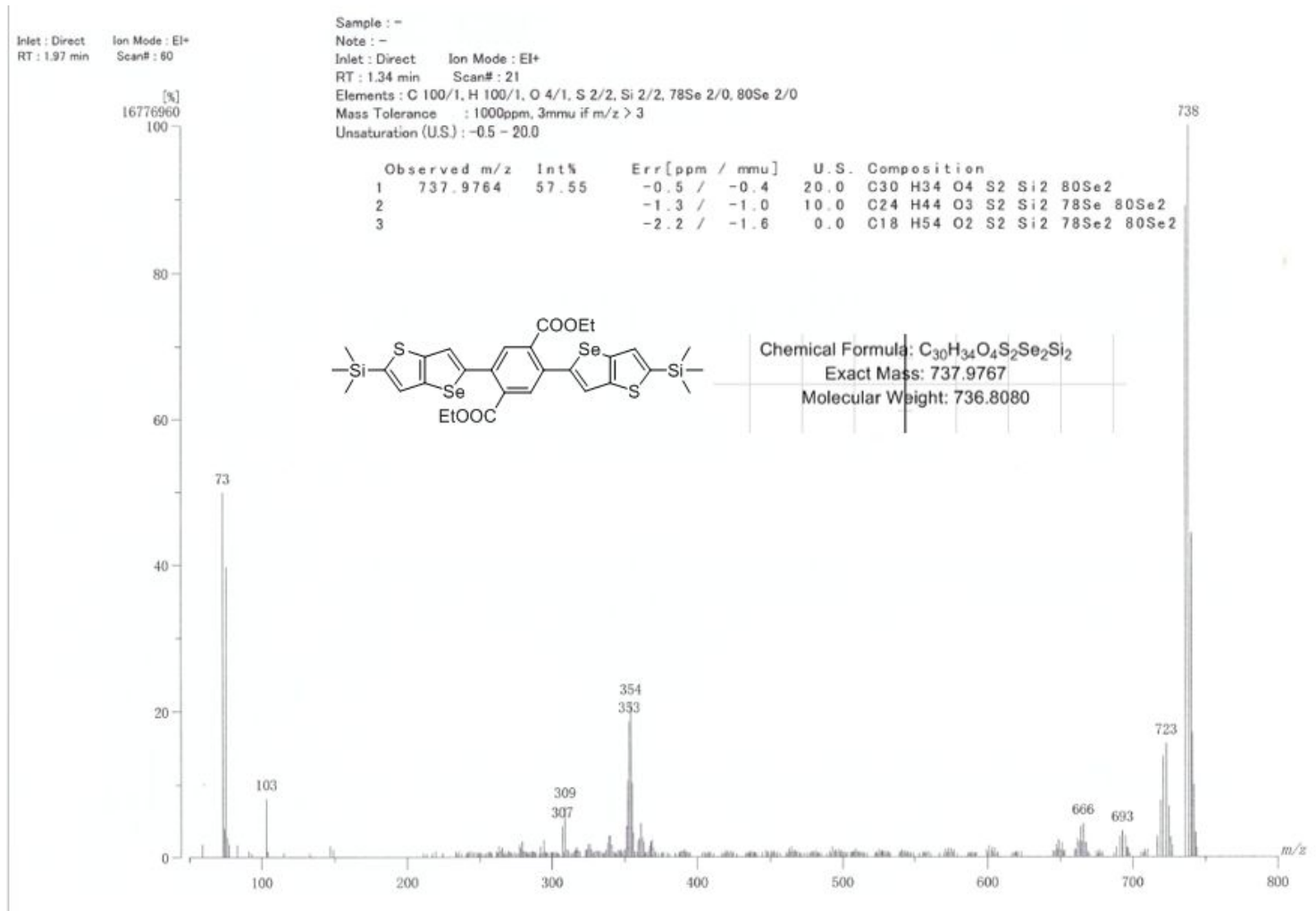

Figure S38. Mass spectrum of compound (11)

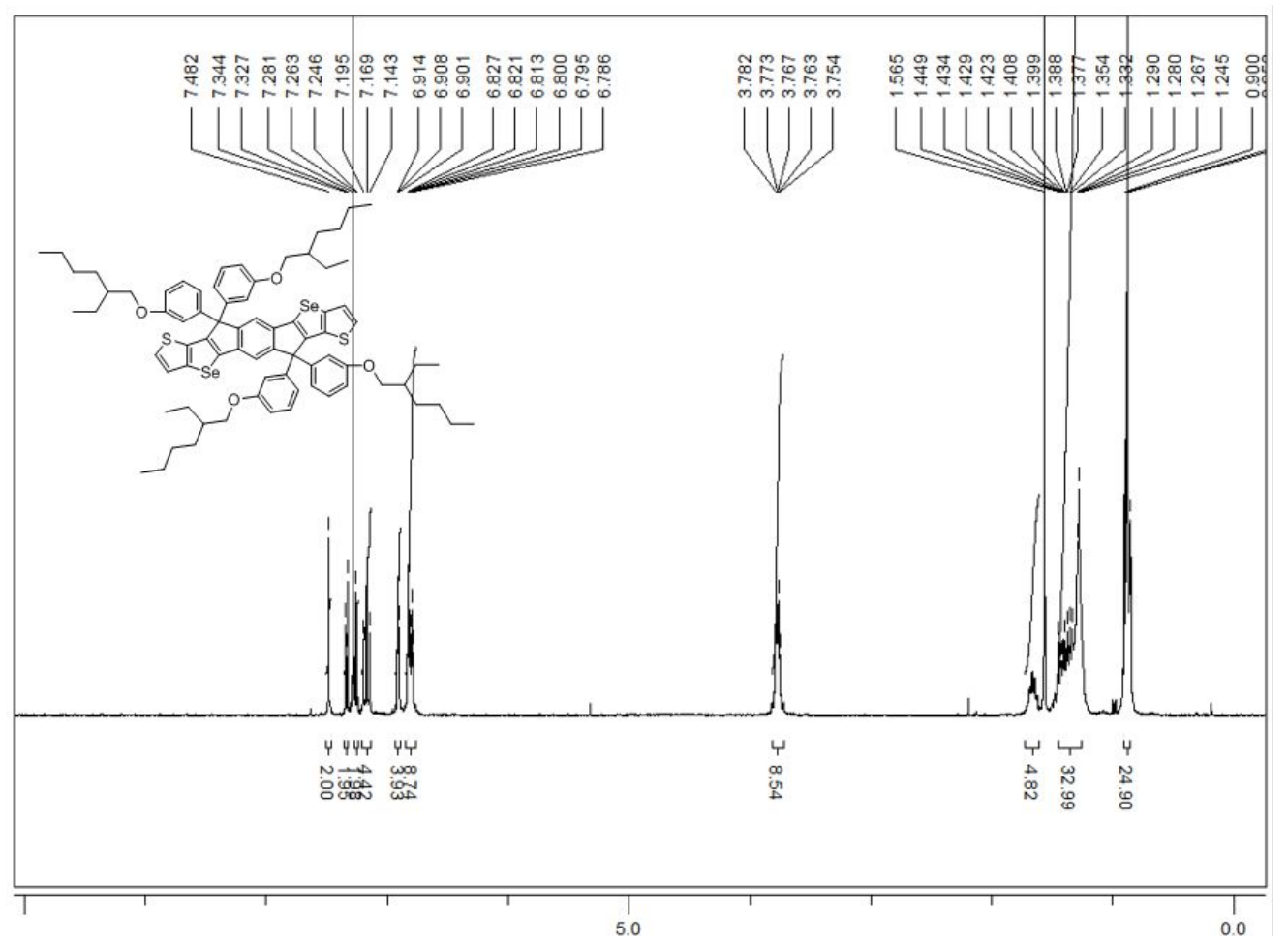

Figure S39. ${ }^{1} \mathrm{H}-\mathrm{NMR}$ of compound (12) 


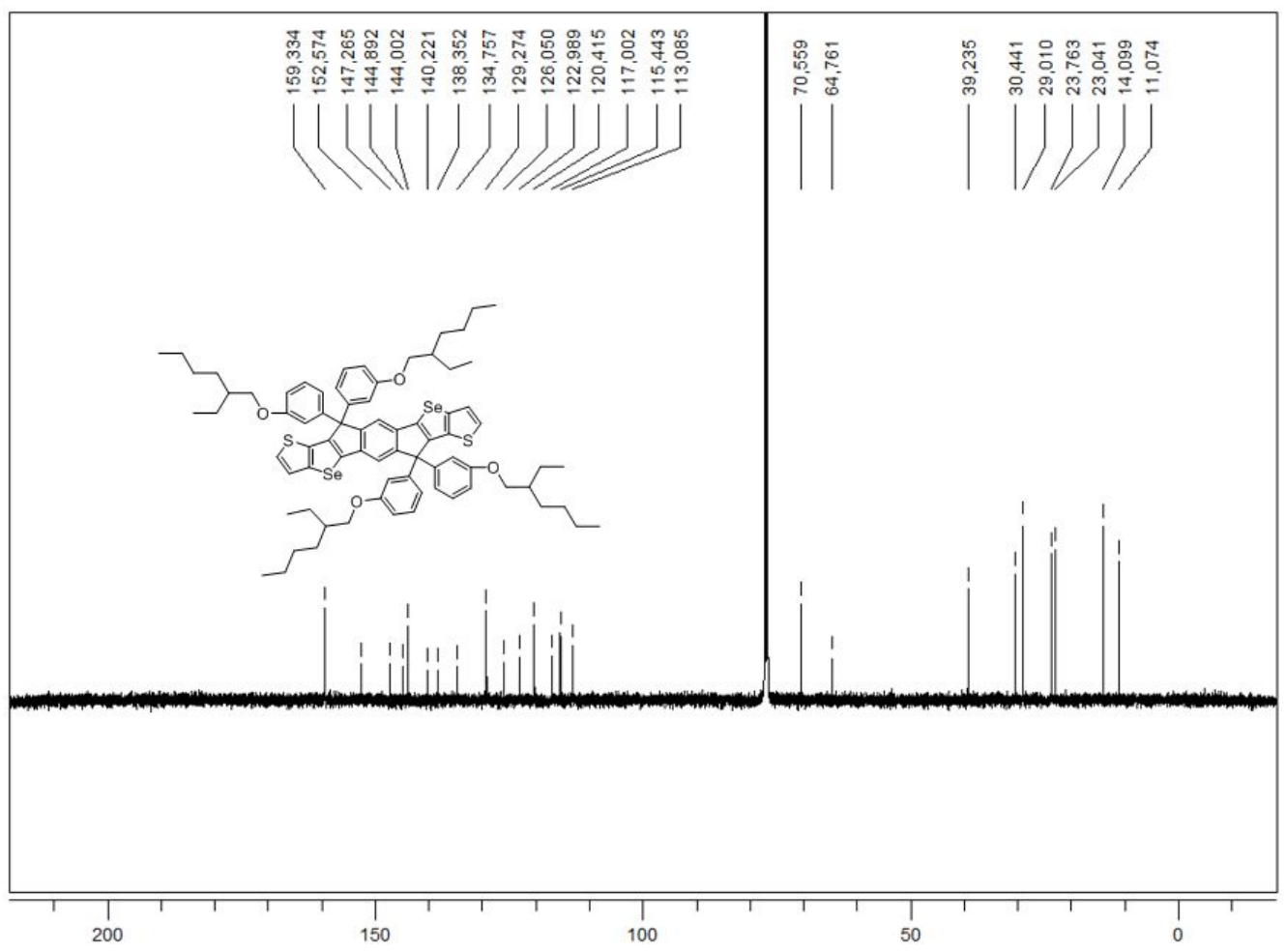

Figure S40. ${ }^{13} \mathrm{C}-\mathrm{NMR}$ of compound (12)

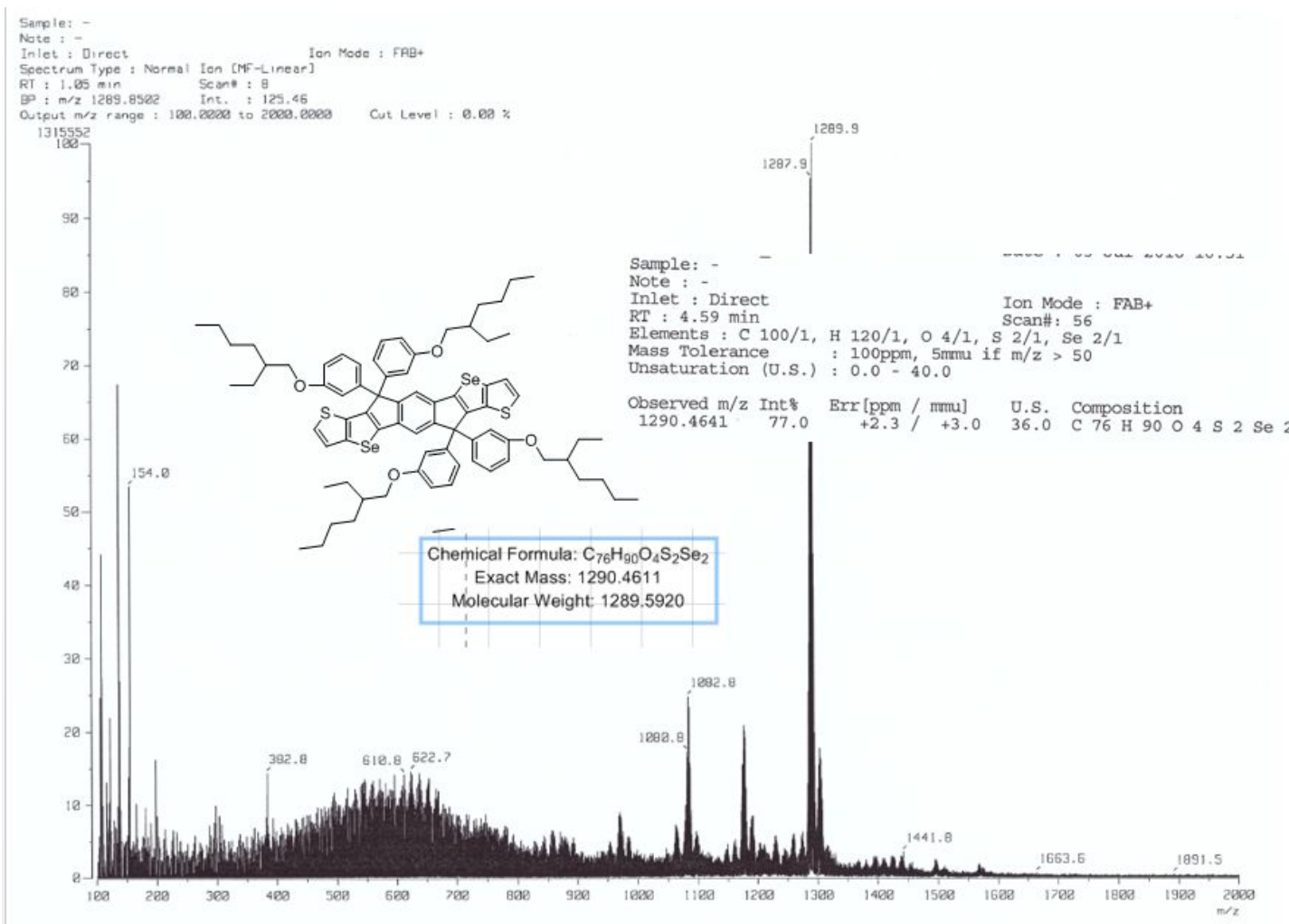

Figure S41. Mass spectrum of compound (12) 


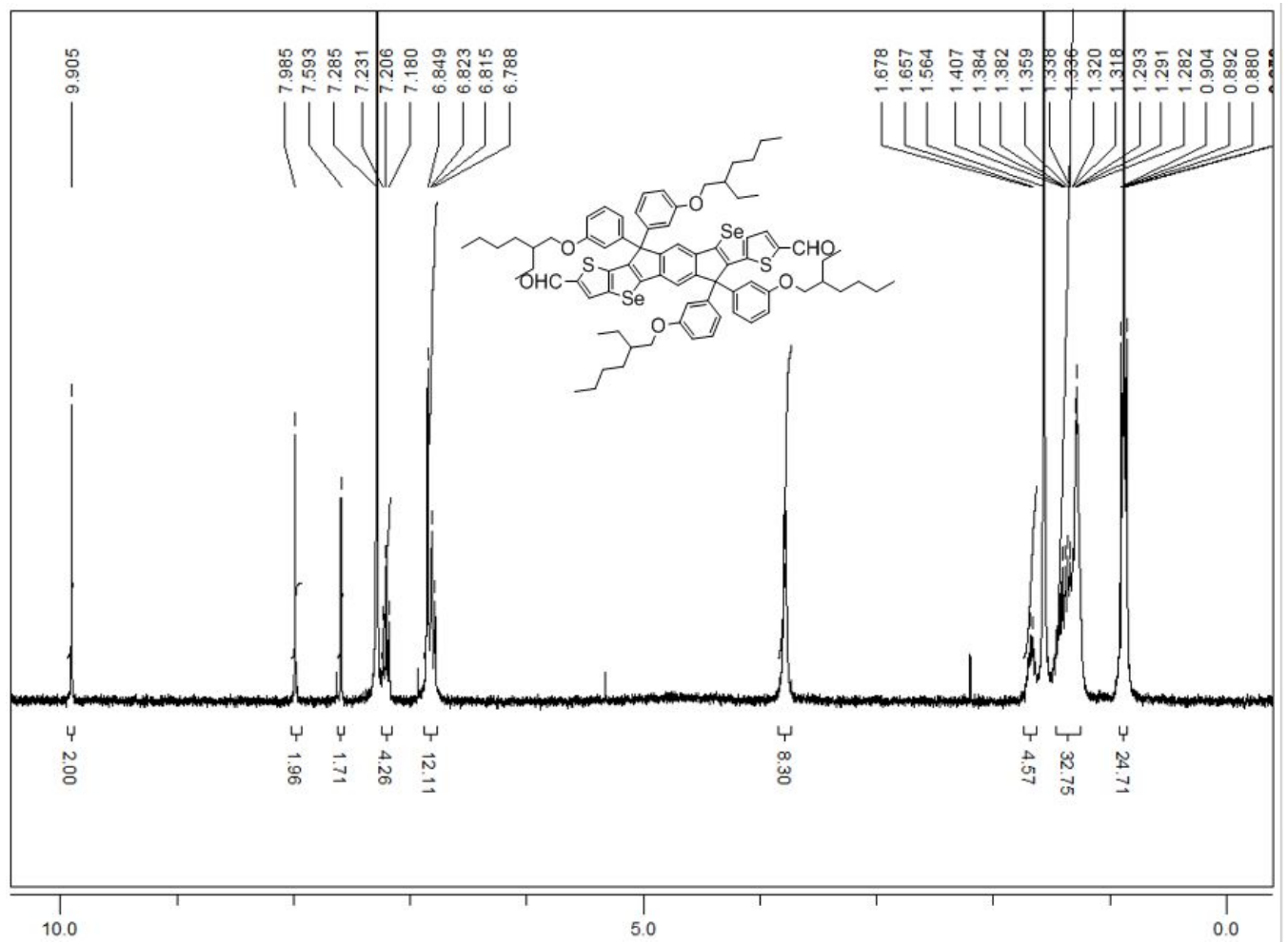

Figure S42. ${ }^{1} \mathrm{H}-\mathrm{NMR}$ of compound (13)

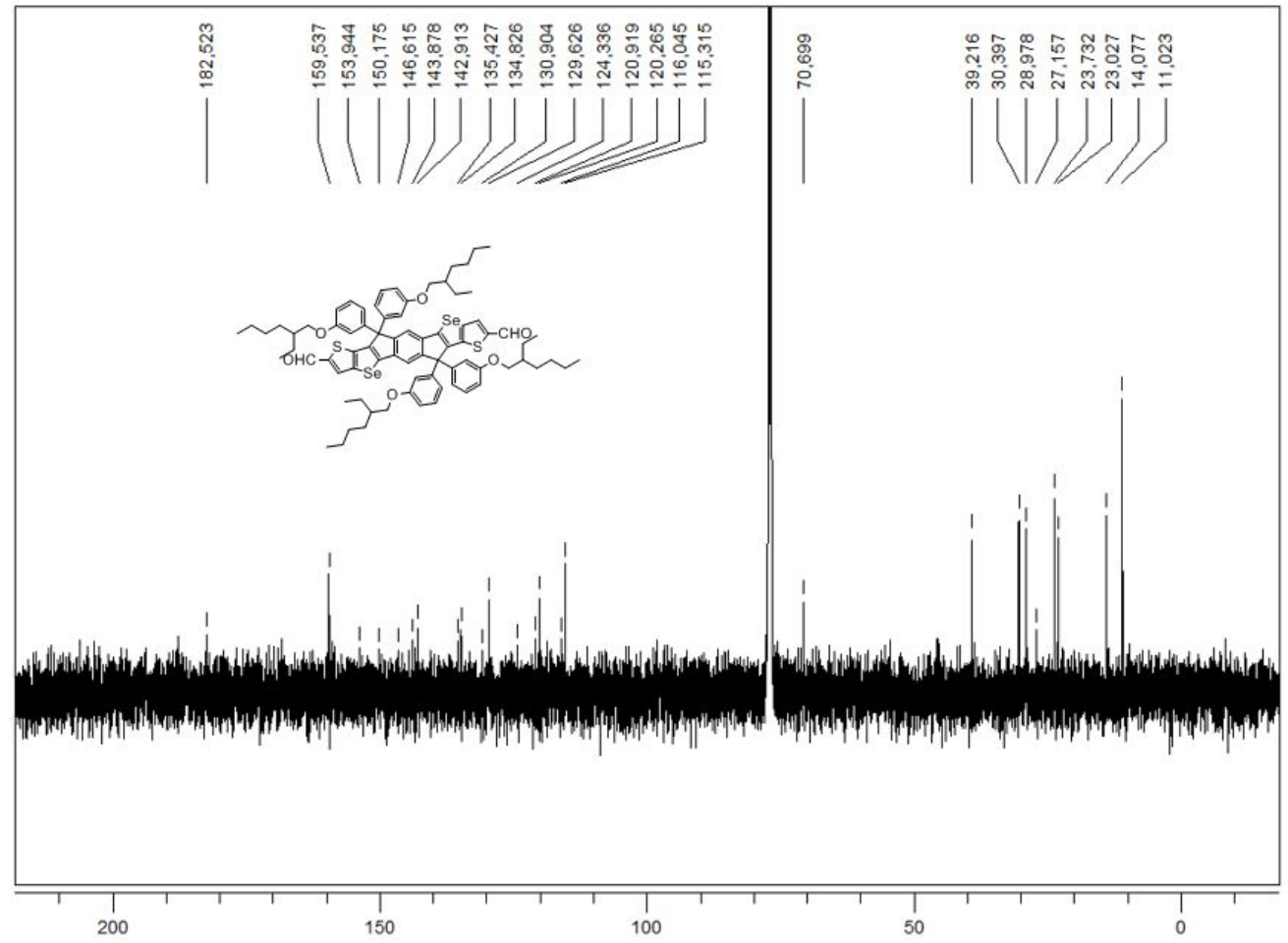

Figure S43. ${ }^{13} \mathrm{C}-\mathrm{NMR}$ of compound (13) 


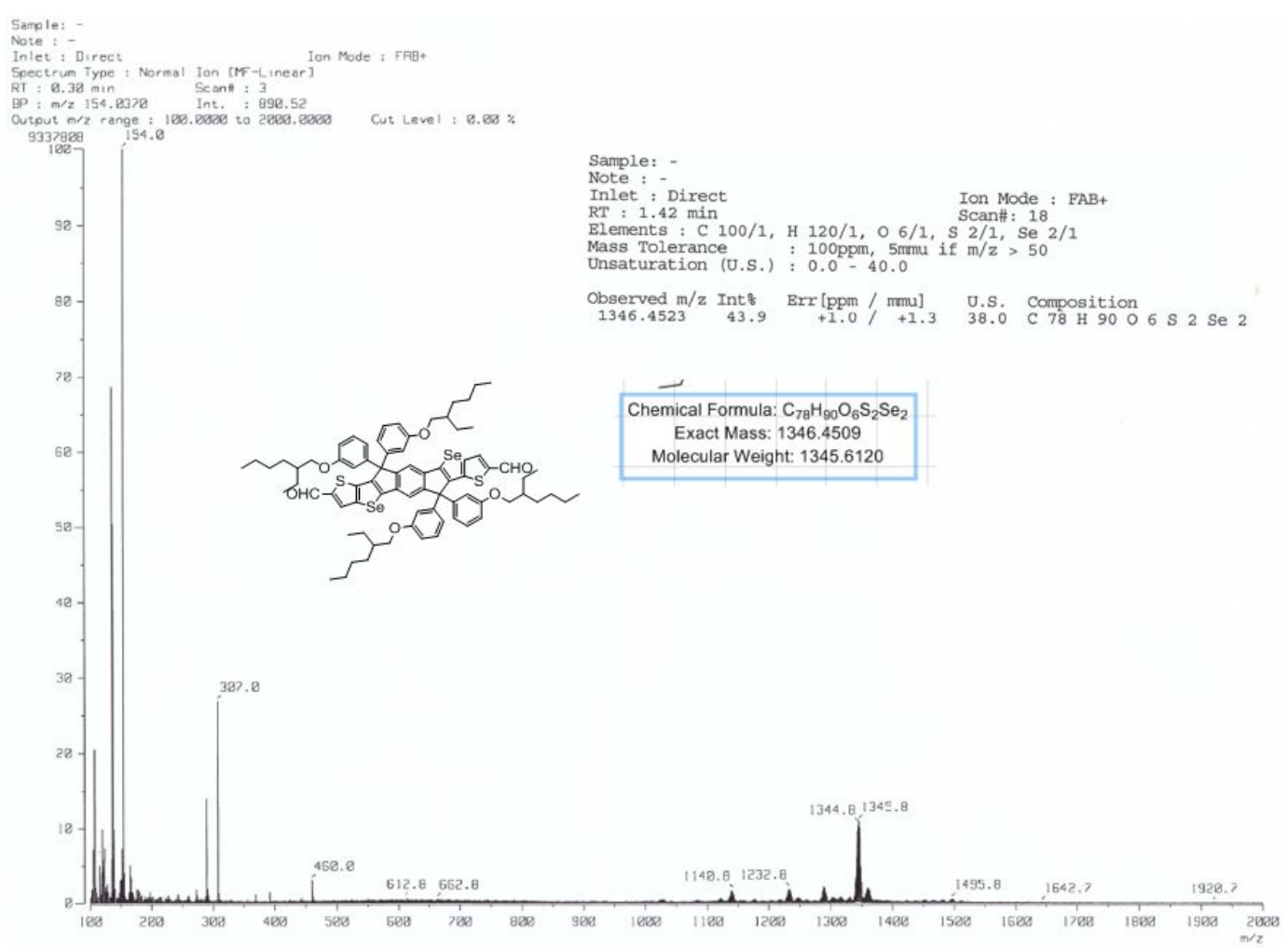

Figure S44. Mass spectrum of compound (13)

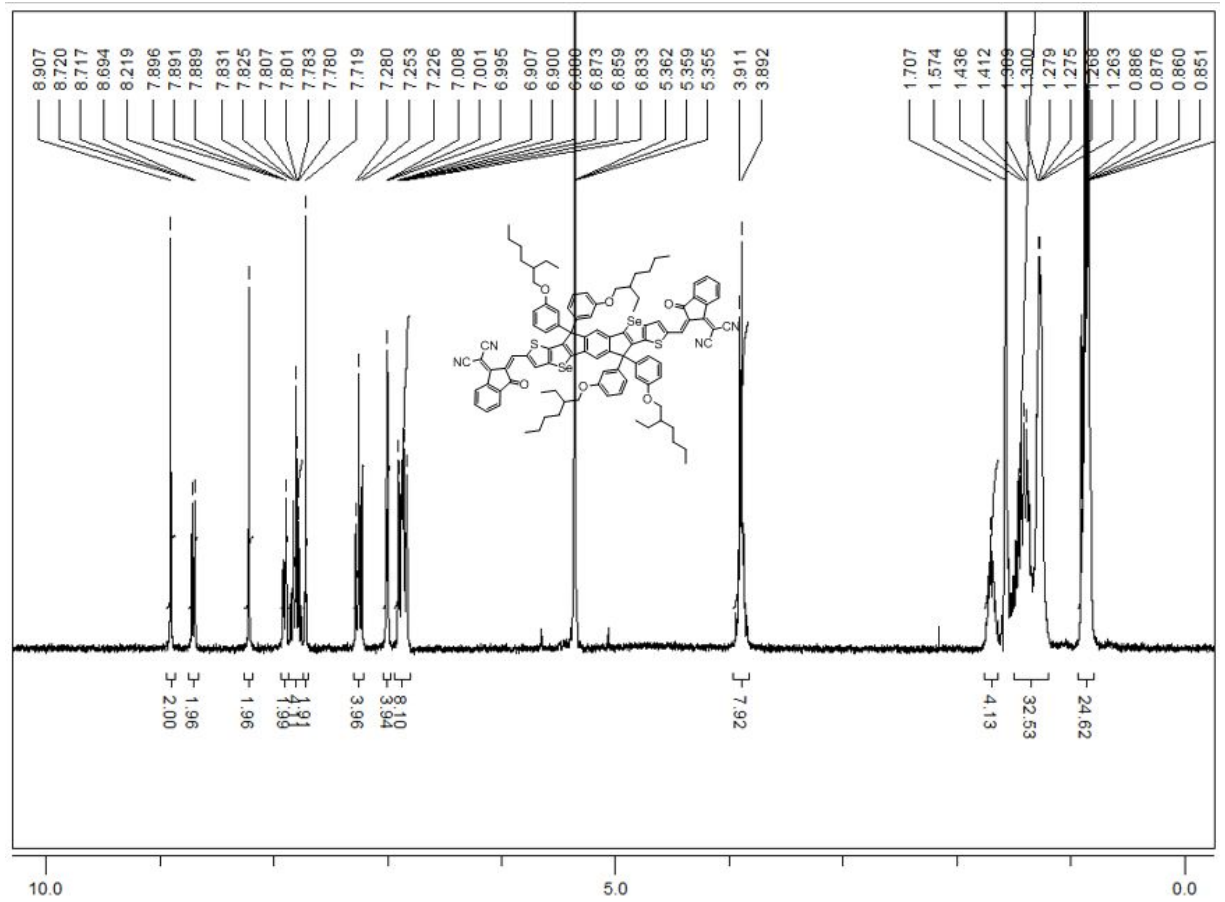

Figure S45. ${ }^{1} \mathrm{H}-\mathrm{NMR}$ of compound (SeIn) 


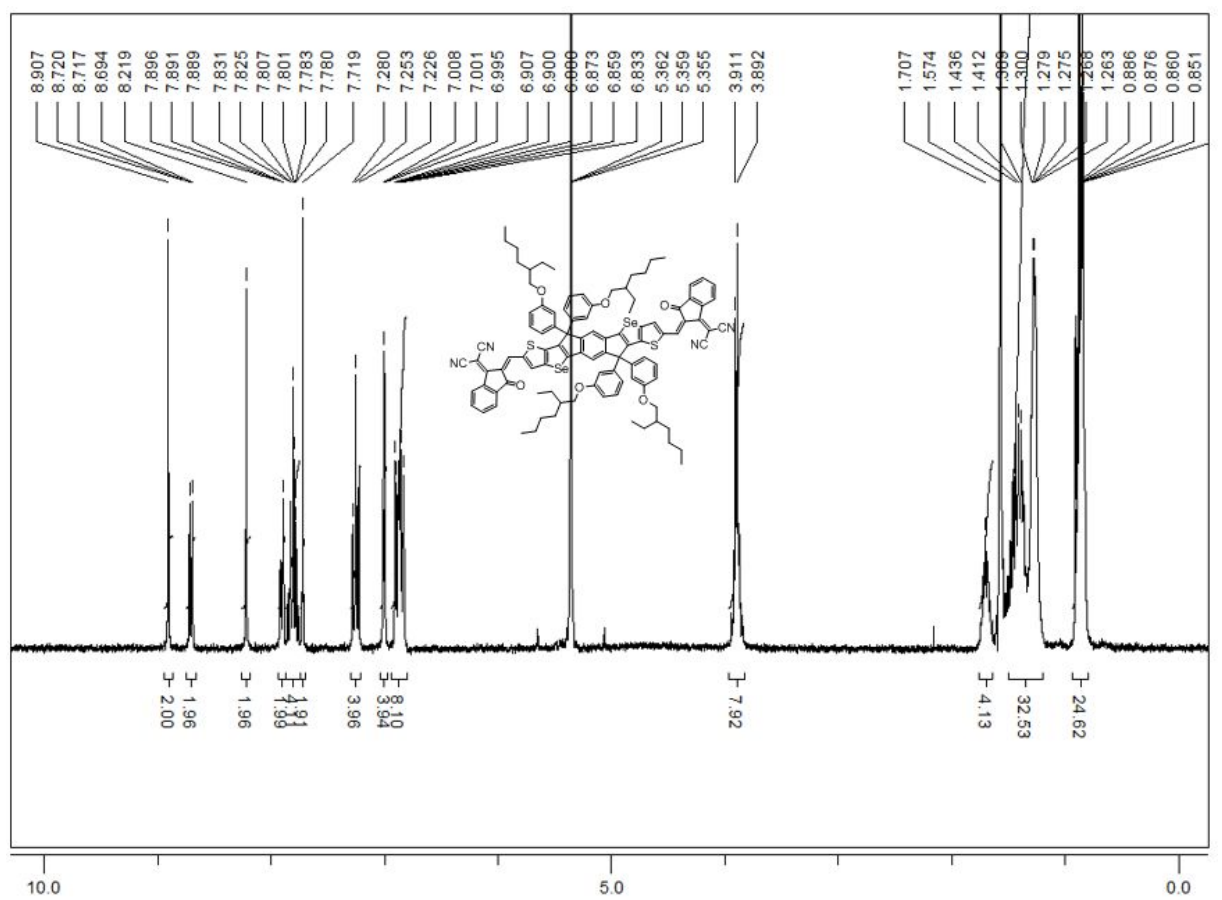

Figure S46. ${ }^{13} \mathrm{C}-\mathrm{NMR}$ of compound (SeIn)

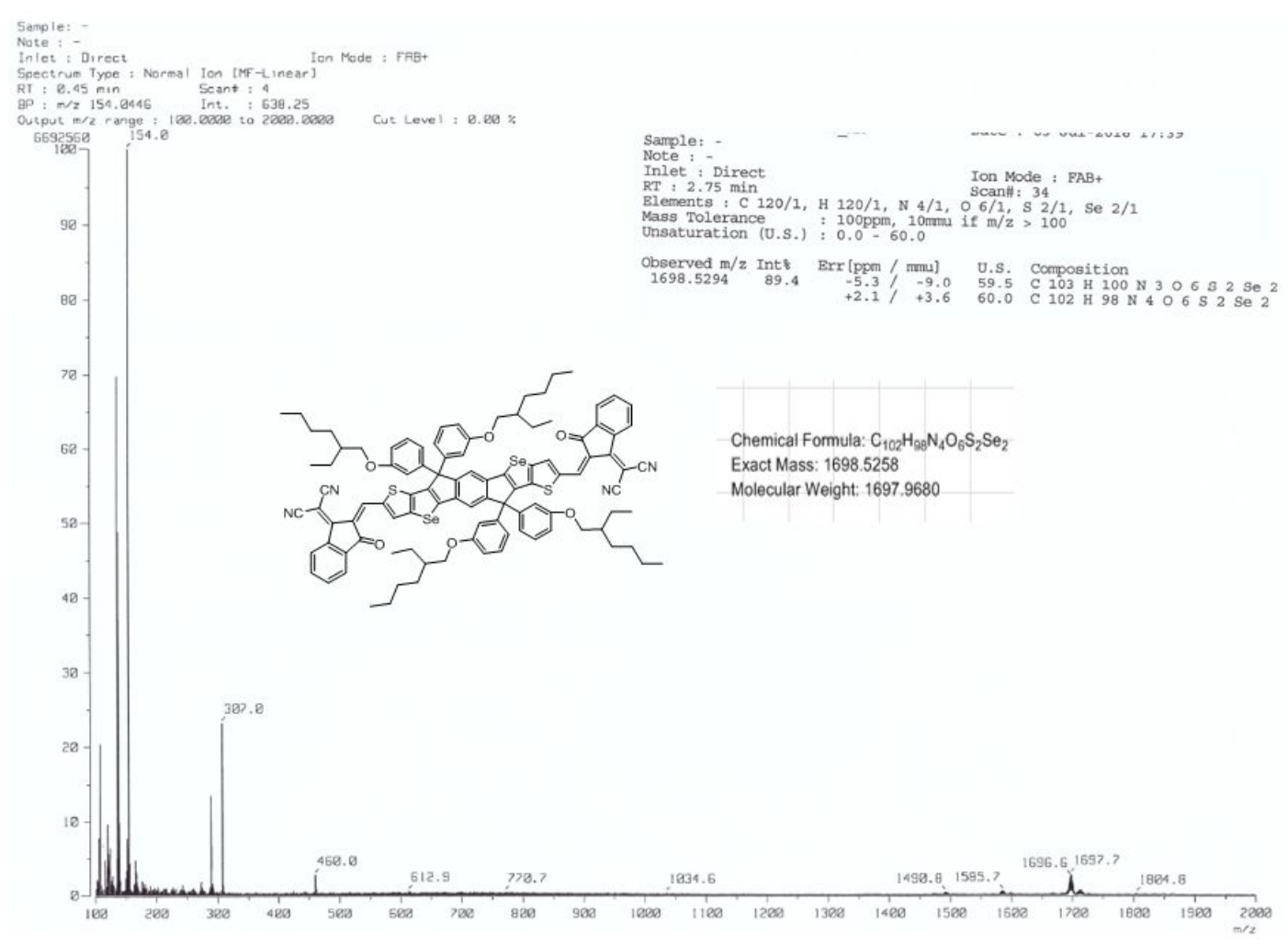

Figure S47. Mass spectrum of compound (SeIn) 


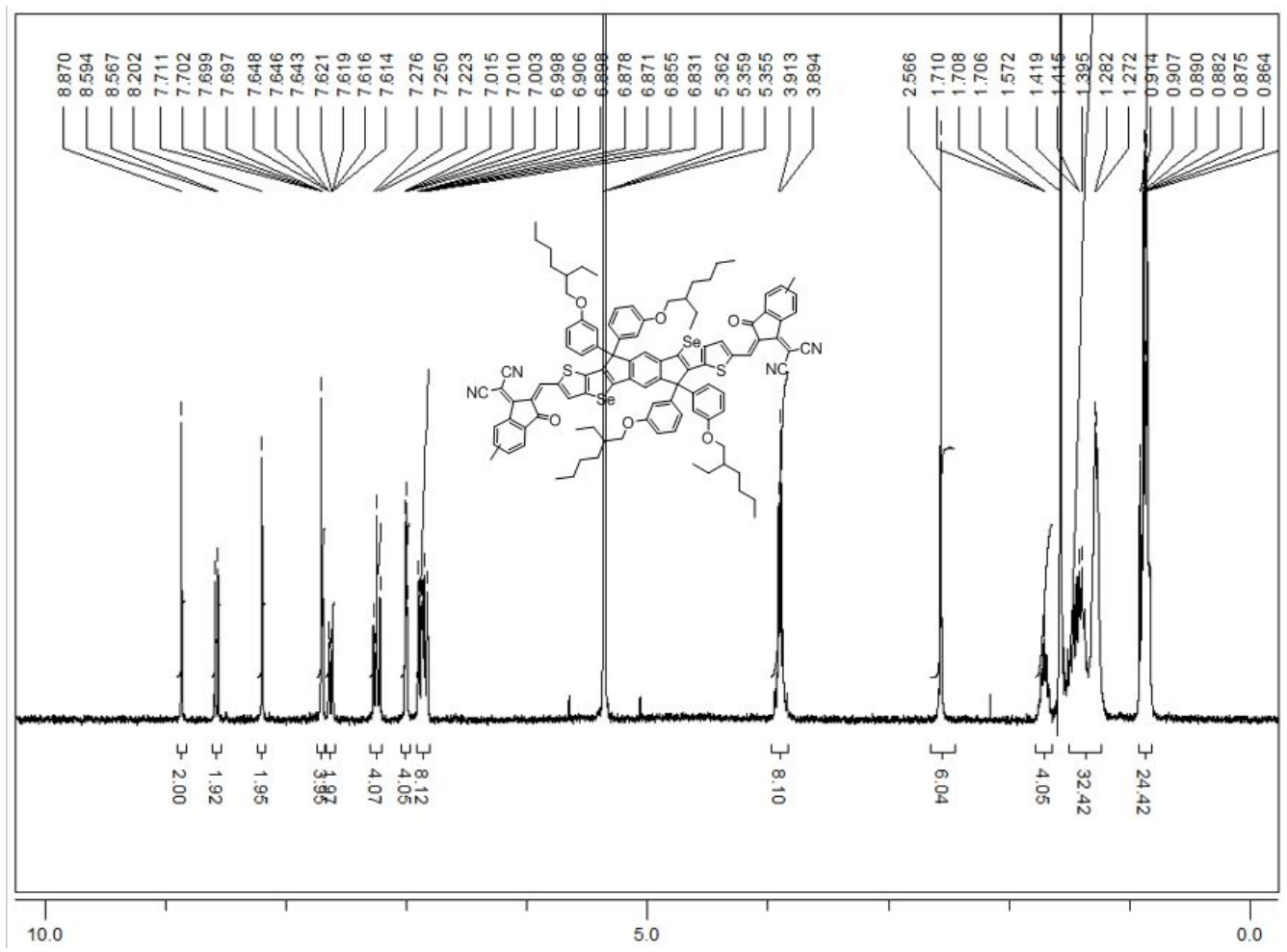

Figure S48. ${ }^{1} \mathrm{H}-\mathrm{NMR}$ of compound (SeInMe)

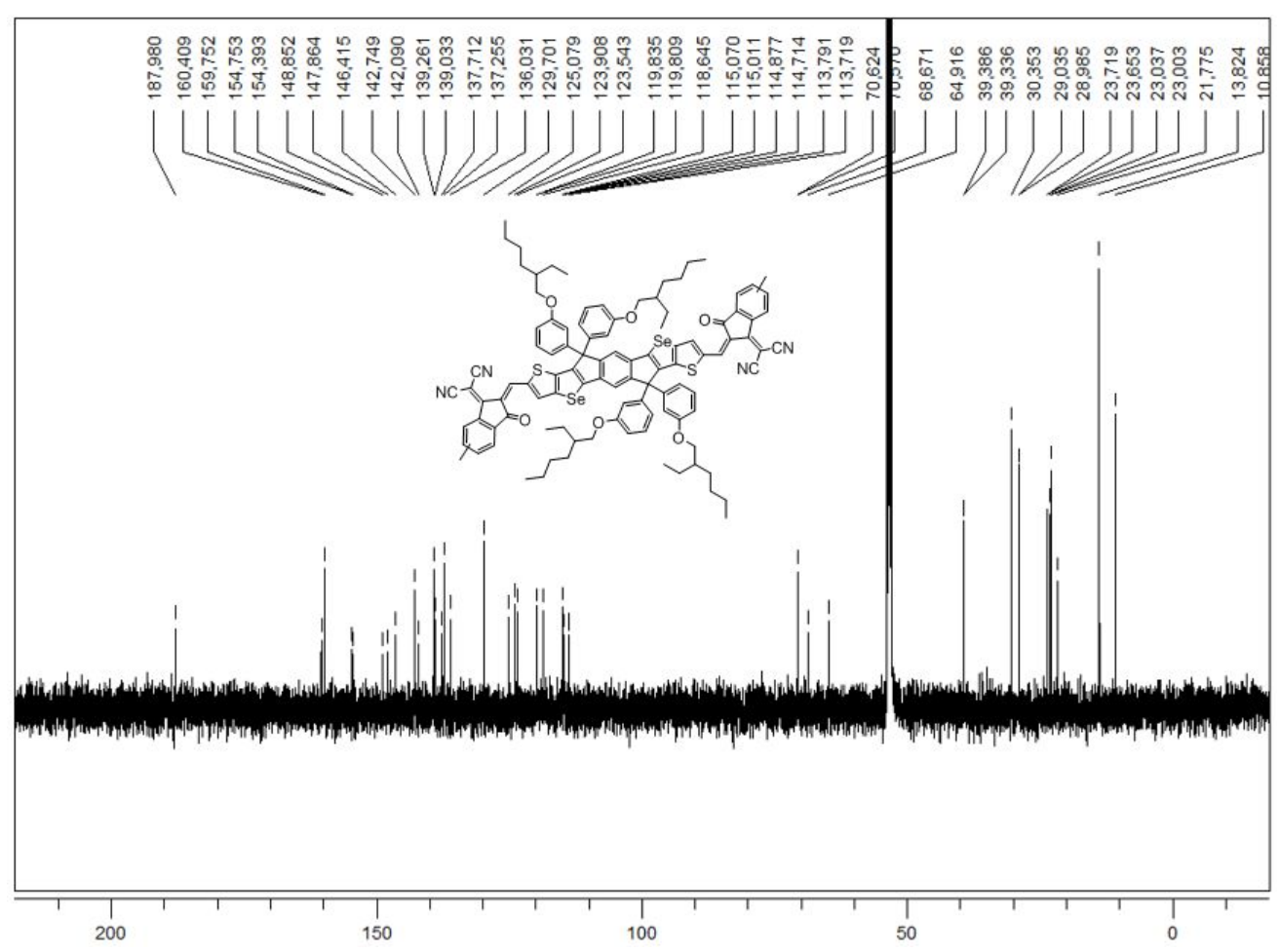

Figure S49. ${ }^{13} \mathrm{C}$-NMR of compound (SeInMe) 


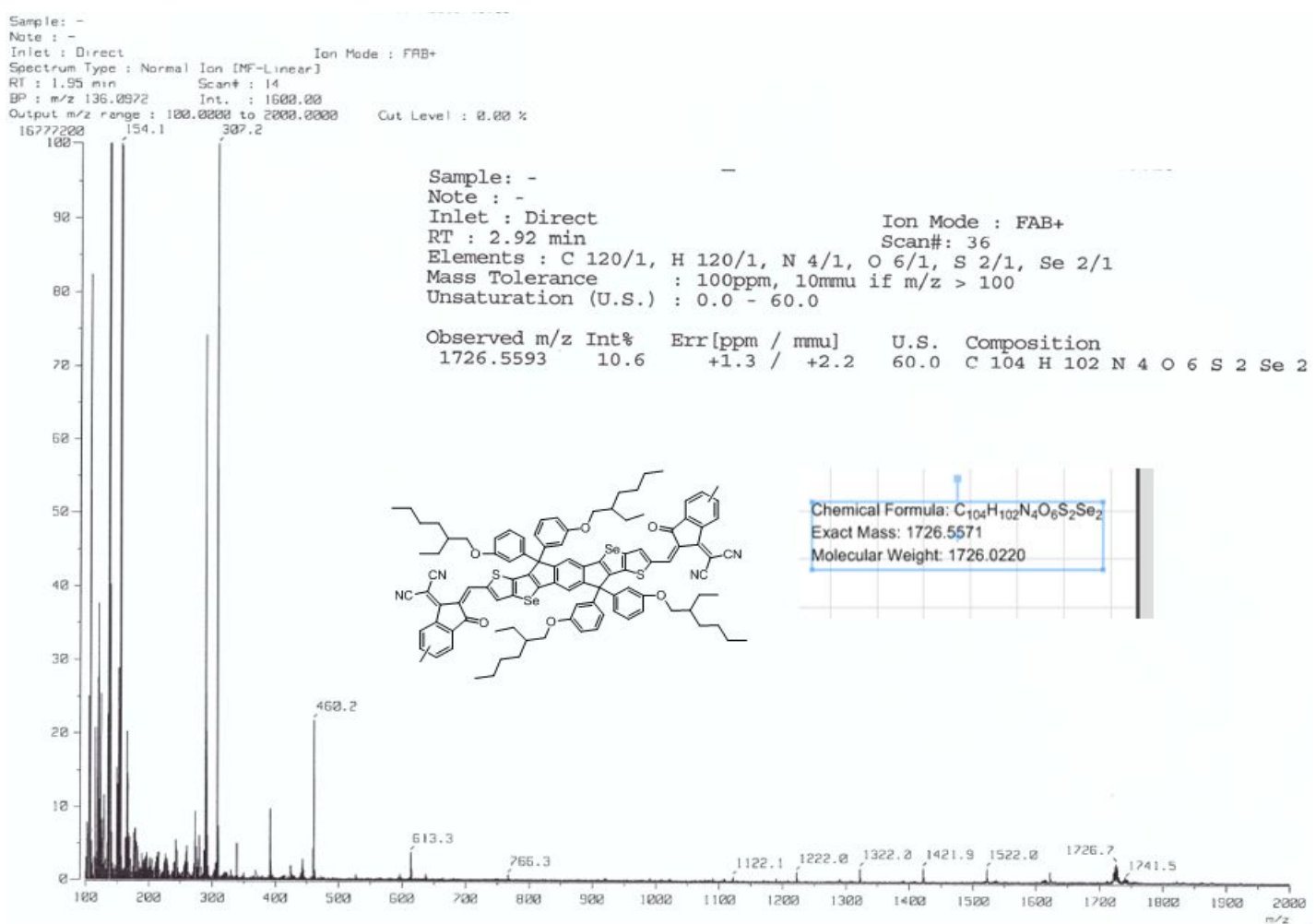

Figure S50. Mass spectrum of compound (SeInMe)
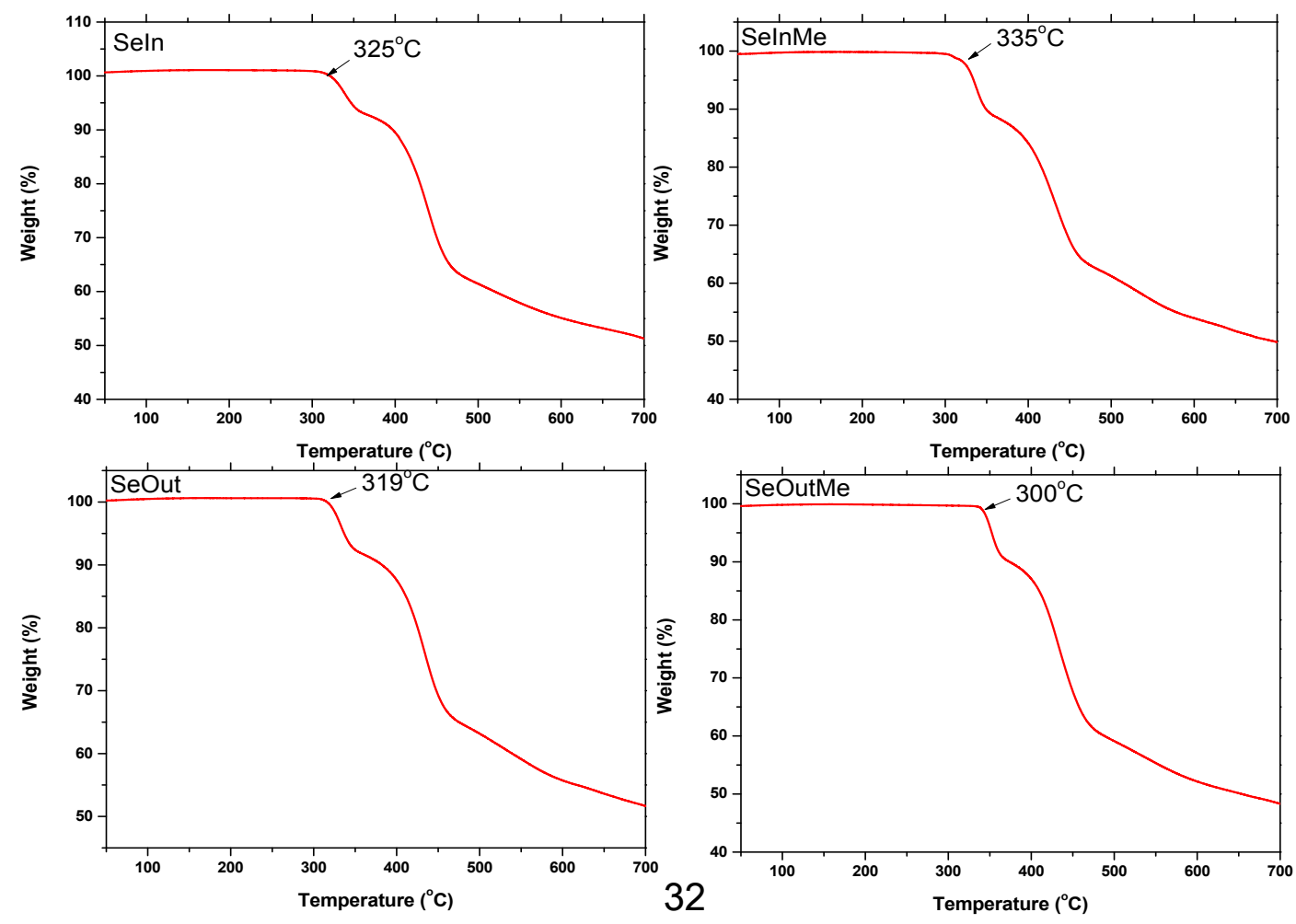
Figure S51. TGA curve of SeIn, SeInMe, SeOut, and SeOutMe.
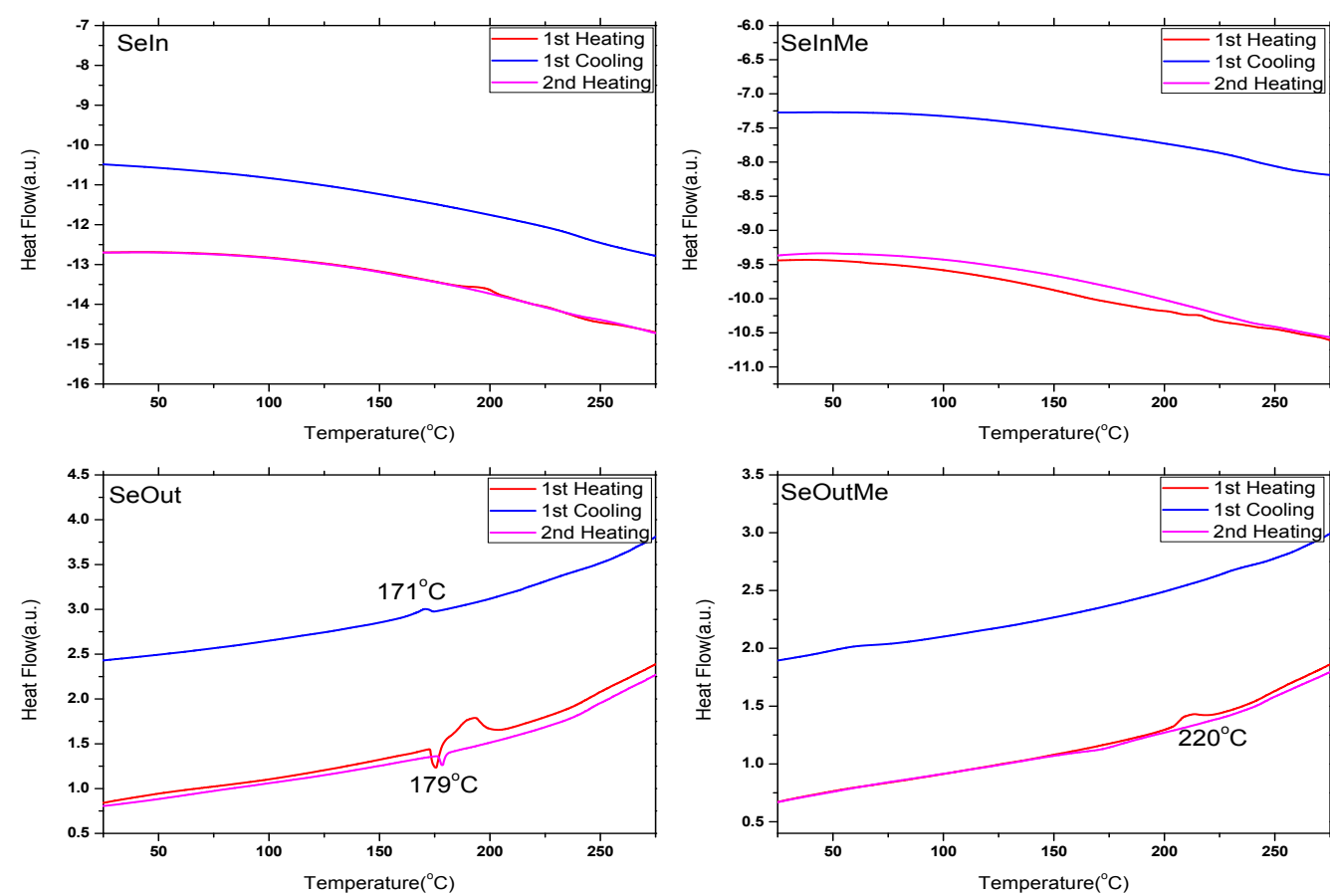

Figure S52. DSC curve of SeIn, SeInMe, SeOut, and SeOutMe.

\begin{tabular}{lccccc}
\hline & $\mathrm{V}_{\mathrm{OC}}(\mathrm{V})$ & $\mathrm{J}_{\mathrm{SC}}\left[\mathrm{mA} / \mathrm{cm}^{2}\right]$ & $\mathrm{FF}$ & $\mathrm{PCE}[\%]$ & $\mathrm{T}_{50}[\mathrm{~h}]$ \\
\hline SeIn & $0.88(0.86)$ & $17.40(16.29)$ & $0.56(0.54)$ & $8.61(7.50)$ & 140 \\
SeInMe & $0.91(0.90)$ & $15.90(15.02)$ & $0.61(0.57)$ & $8.80(7.68)$ & 860 \\
SeOut & $0.88(0.87)$ & $16.90(15.68)$ & $0.62(0.58)$ & $9.25(7.92)$ & 910 \\
SeOutMe & $0.90(0.89)$ & $16.70(15.58)$ & $0.64(0.62)$ & $9.68(8.58)$ & 5630 \\
ITIC & 0.90 & 17.70 & 0.62 & 9.91 & 410 \\
\hline
\end{tabular}

Table S1. Champion and average photovoltaic parameters for $\sim 15$ devices and $\mathrm{T}_{50}$ lifetime for PBDB-T:NFA solar cells. $\mathrm{T}_{50}$, the time required for PCE to drop to $50 \%$ of the original value, is calculated from the starting measurement, without considering the initial fast decay in the burn-in phase. The data are directly measured for SeIn and ITIC, while extrapolated by linear fit for the other NFAs. 


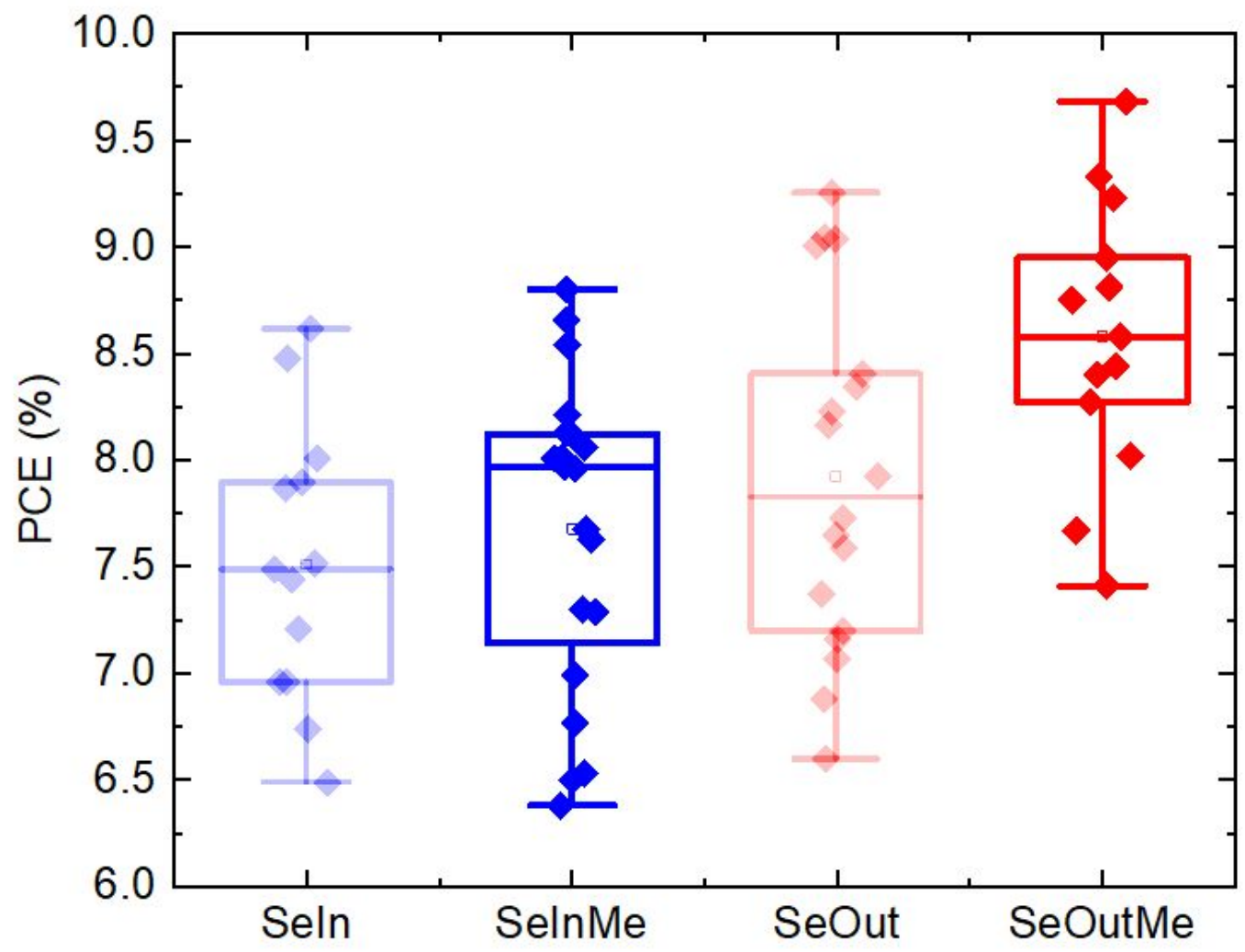

Figure S53. Distribution of power conversion efficiency for devices fabricated with different selenated non-fullerene acceptors (polymer PBDB-T as donor). $\sim 15$ devices have been tested in each case, whose average photovoltaic parameters are reported in Table S1. 

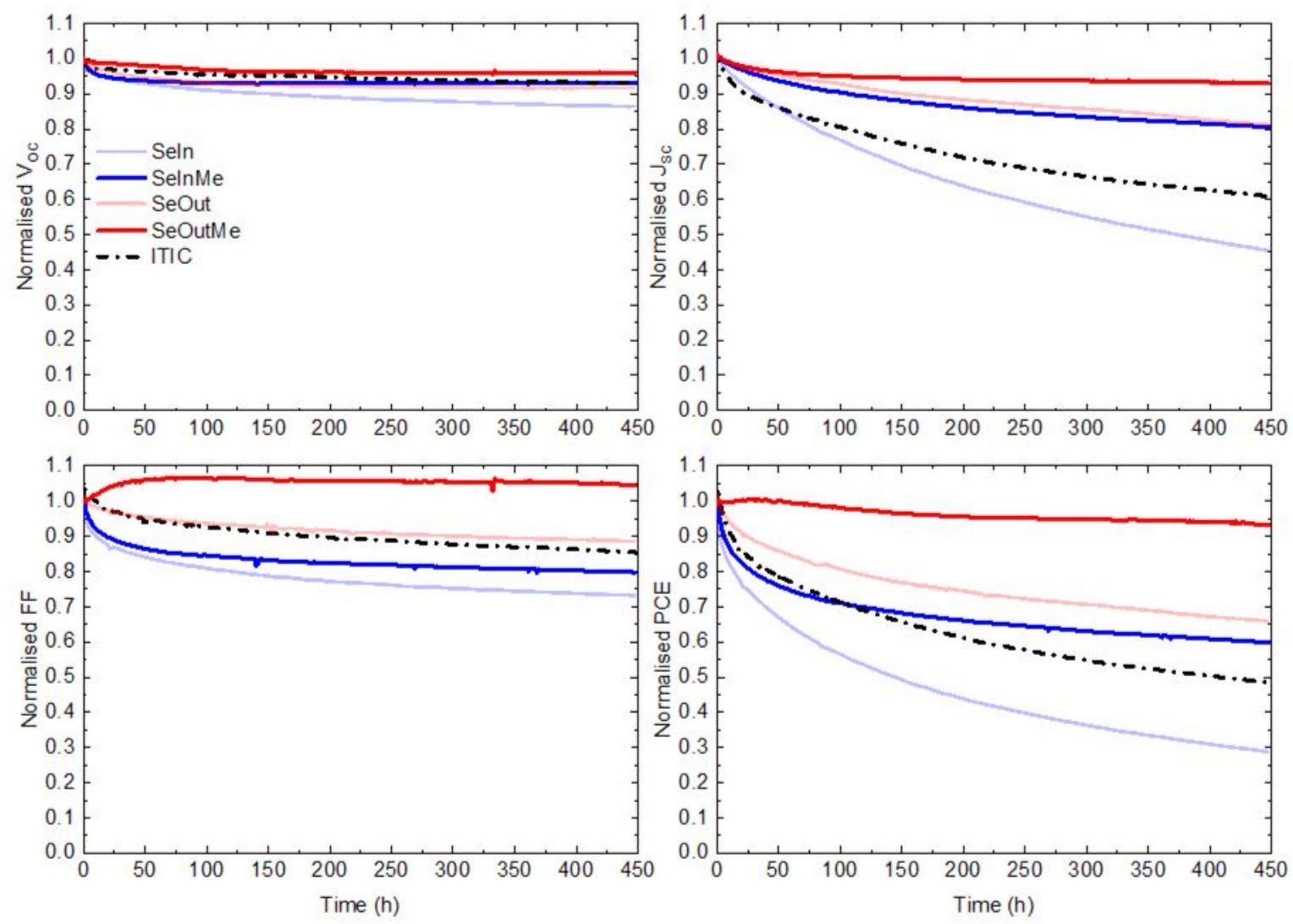

Figure S54. Evolution of all photovoltaic parameters of PBDB-T:NFA solar cells continuously operated under white LED light source in inert atmosphere. 

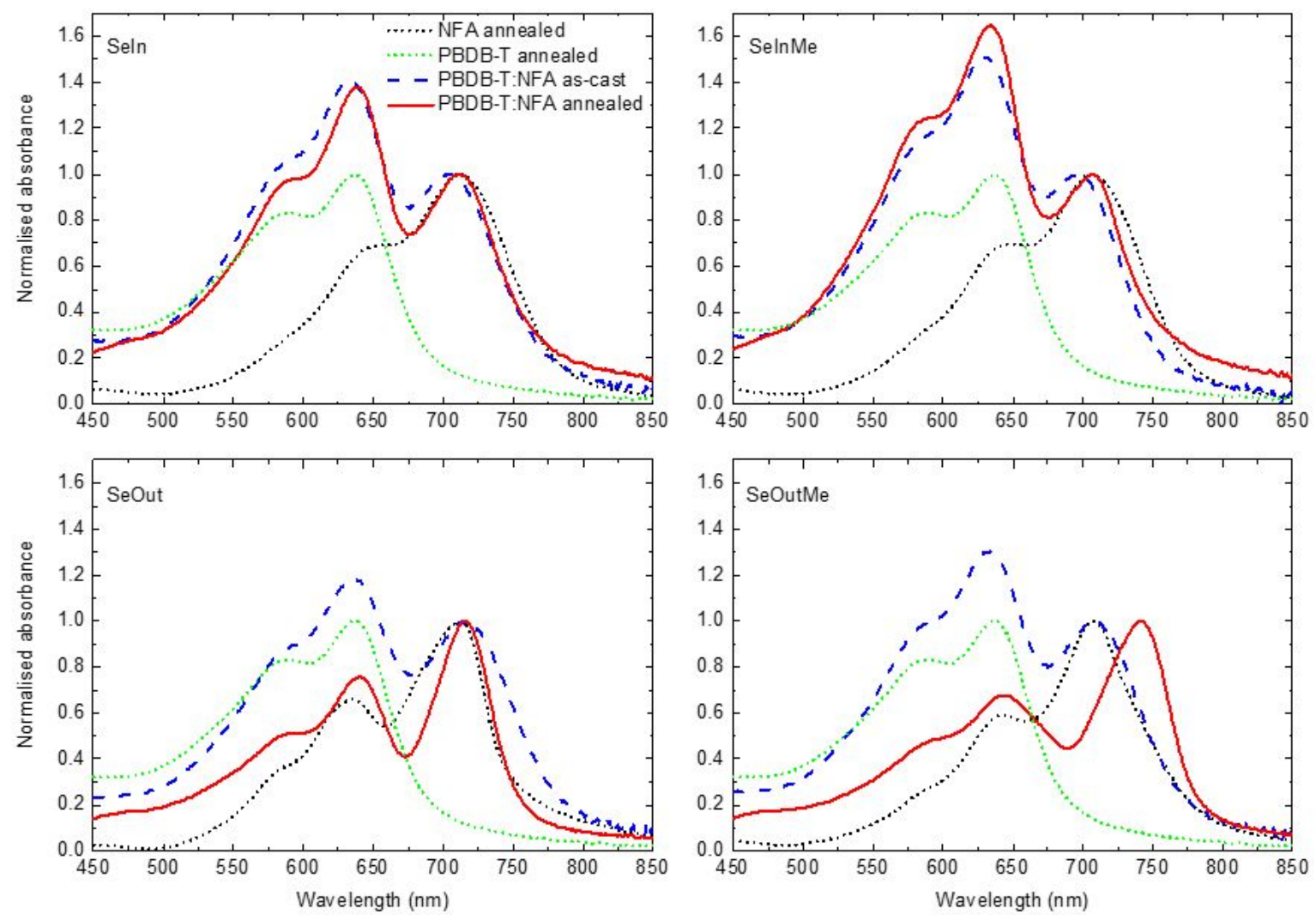

Figure S55. UV-Vis absorption spectra of the different NFA blends, comparing the neat acceptor and donor with the as-cast and annealed thin films of respective blends. 


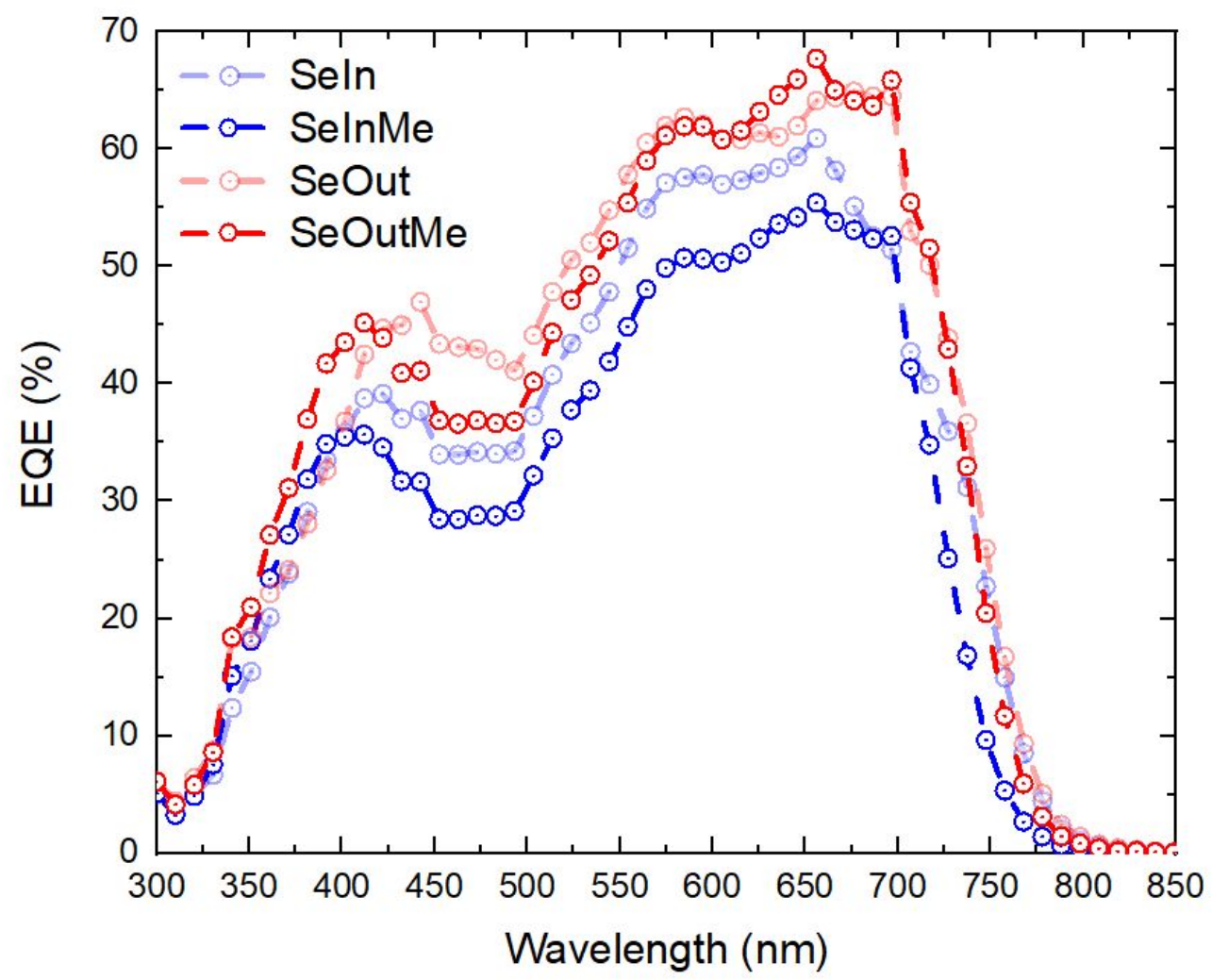

Figure S56. EQE spectra measured for PBDB-T:NFA devices. 


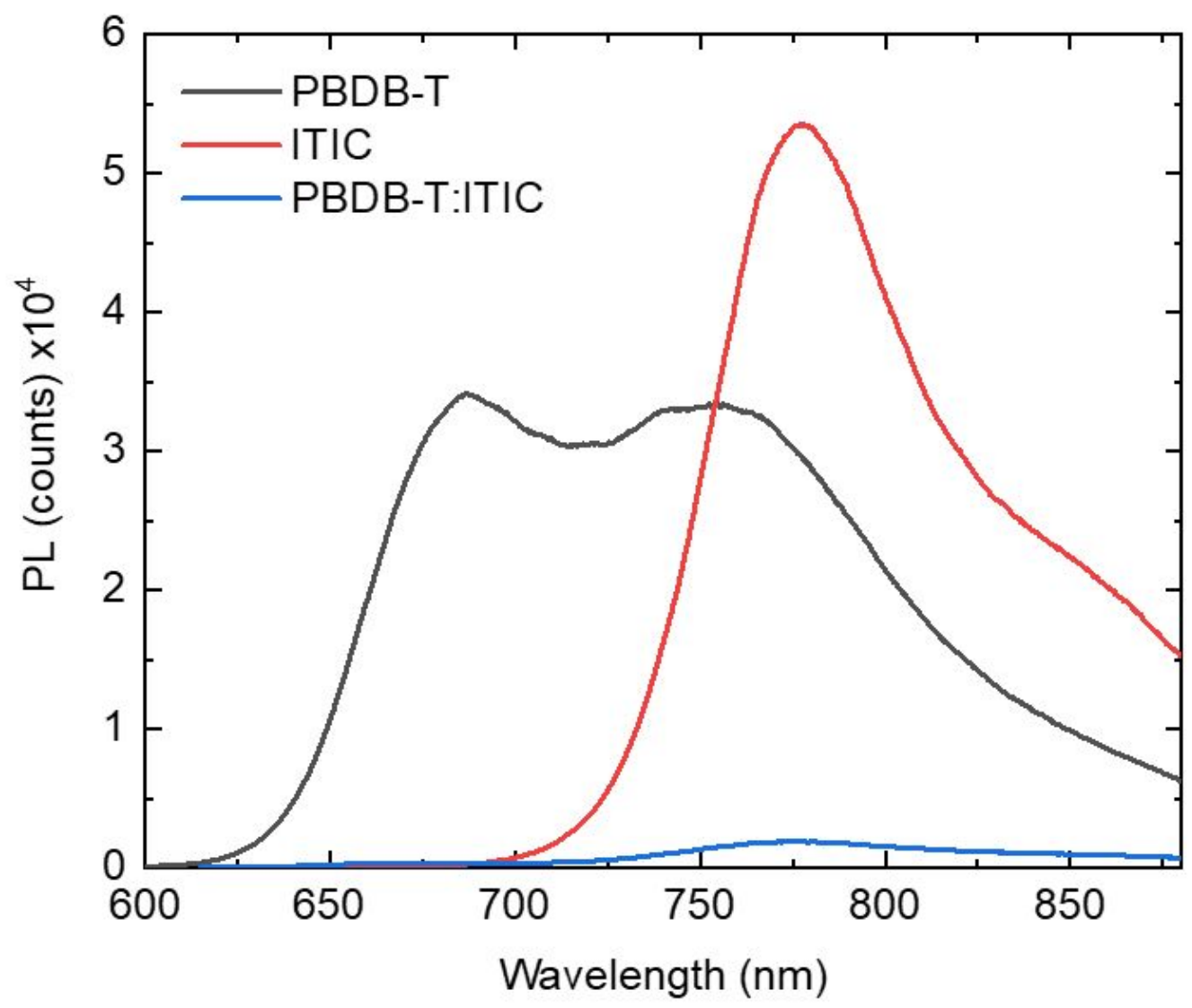

Figure S57. Photoluminescence spectra of PBDB-T:ITIC blend and of the neat donor and acceptor films.

\begin{tabular}{|l|l|l|}
\hline PL quenching & NFA & PBDB-T \\
\hline SeIn & 93 & 99 \\
\hline SeInMe & 88 & 99 \\
\hline SeOut & 74 & 97 \\
\hline SeOutMe & 44 & 94 \\
\hline ITIC & 97 & 99 \\
\hline
\end{tabular}

Table S2. Summary of PL quenching for the different NFA blends with respect to the neat donor and acceptor components. 

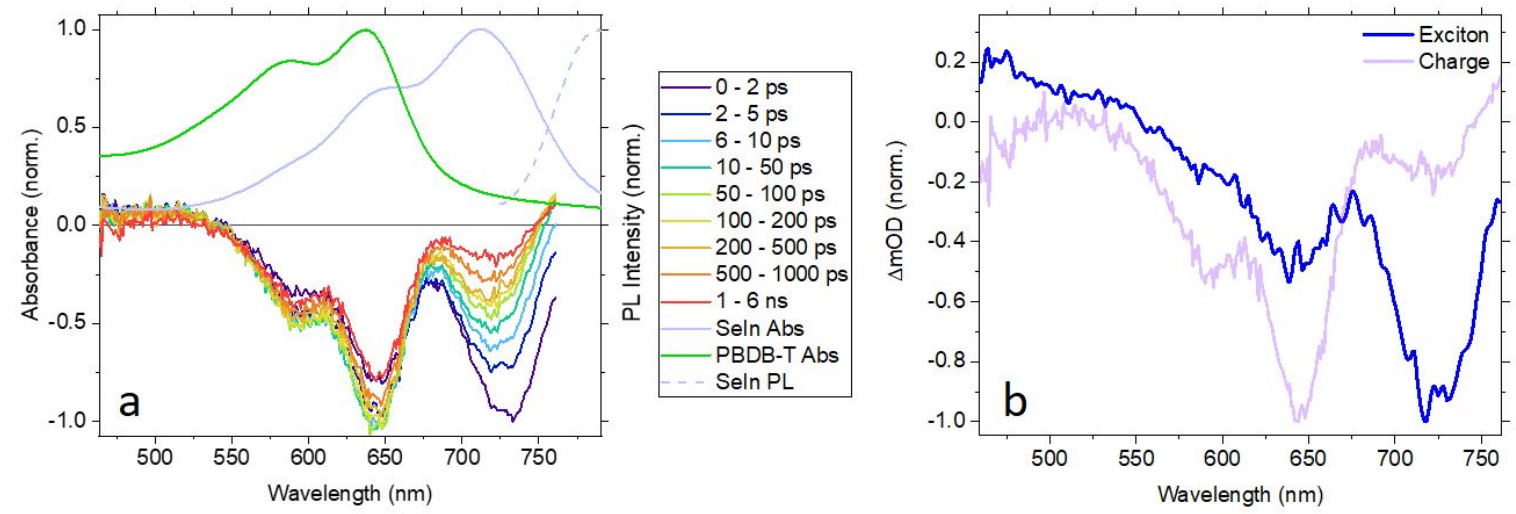

Figure S58. (a) Transient spectra for PBDB-T:SeIn blends compared with UV-Vis absorbance of neat donor and acceptor and neat NFA PL. (b) Spectra relative to charge and excitonic species in SeIn blends extracted from (a) by global analysis.
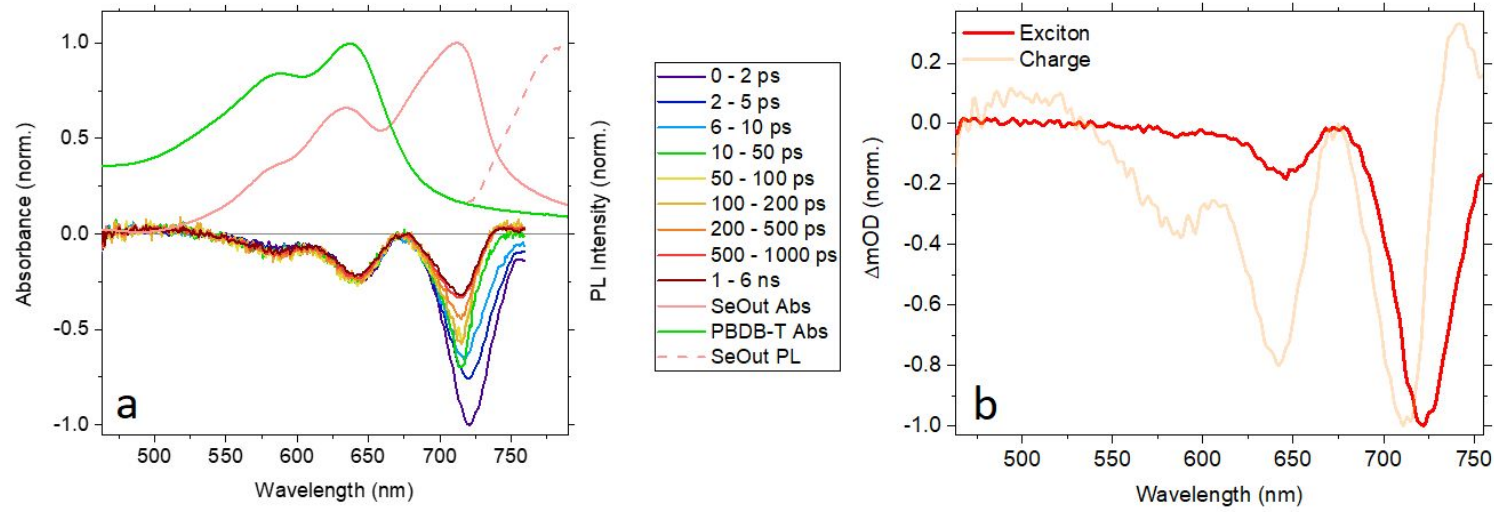

Figure S59. (a) Transient spectra for PBDB-T:SeOut blends compared with UV-Vis absorbance of neat donor and acceptor and neat NFA PL. (b) Spectra relative to charge and excitonic species in SeOut blends extracted from (a) by global analysis. 

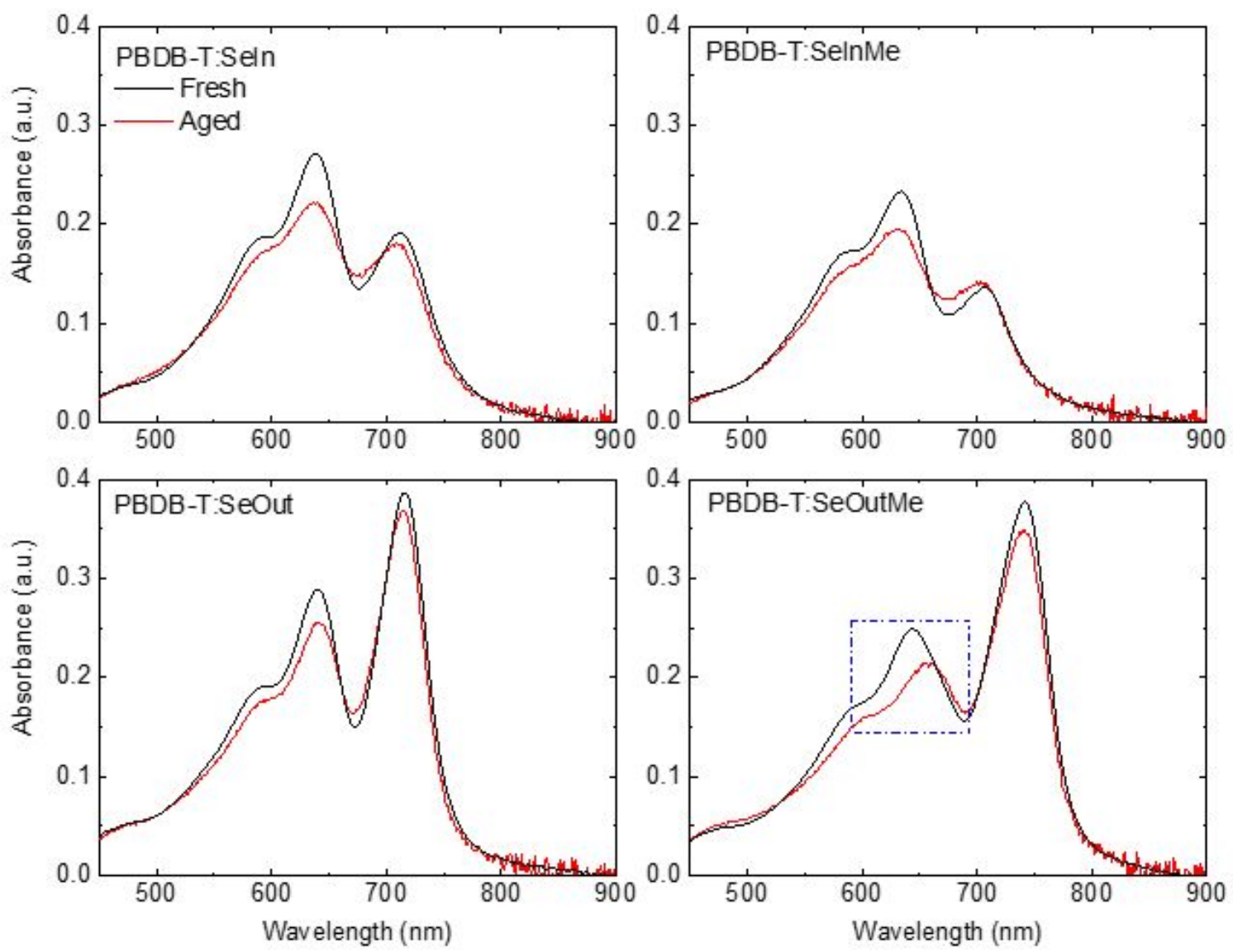

Figure S60. UV-Vis absorbance spectra of fresh and light aged PBDB-T:NFA blends exposed to white LED light source. The dashed square on SeOutMe spectra highlights the red-shift of PBDB-T peak. 

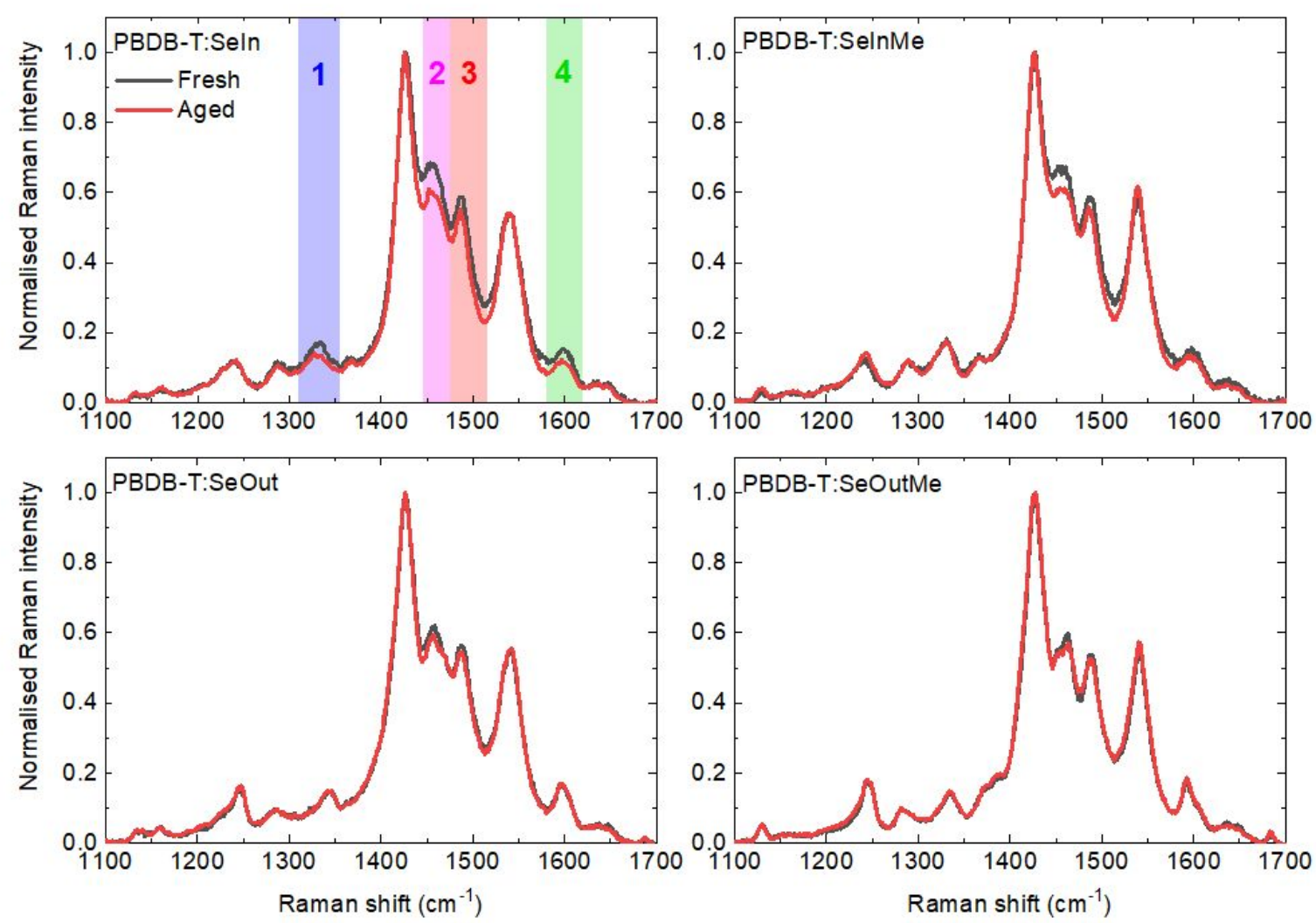

Figure S61. Raman spectra of fresh and aged PBDB-T:NFA blend films. The top left graph relative to SeIn blend shows the peak assignment to some of the vibrational modes as detailed in Figure $3 b$ of the main text. 

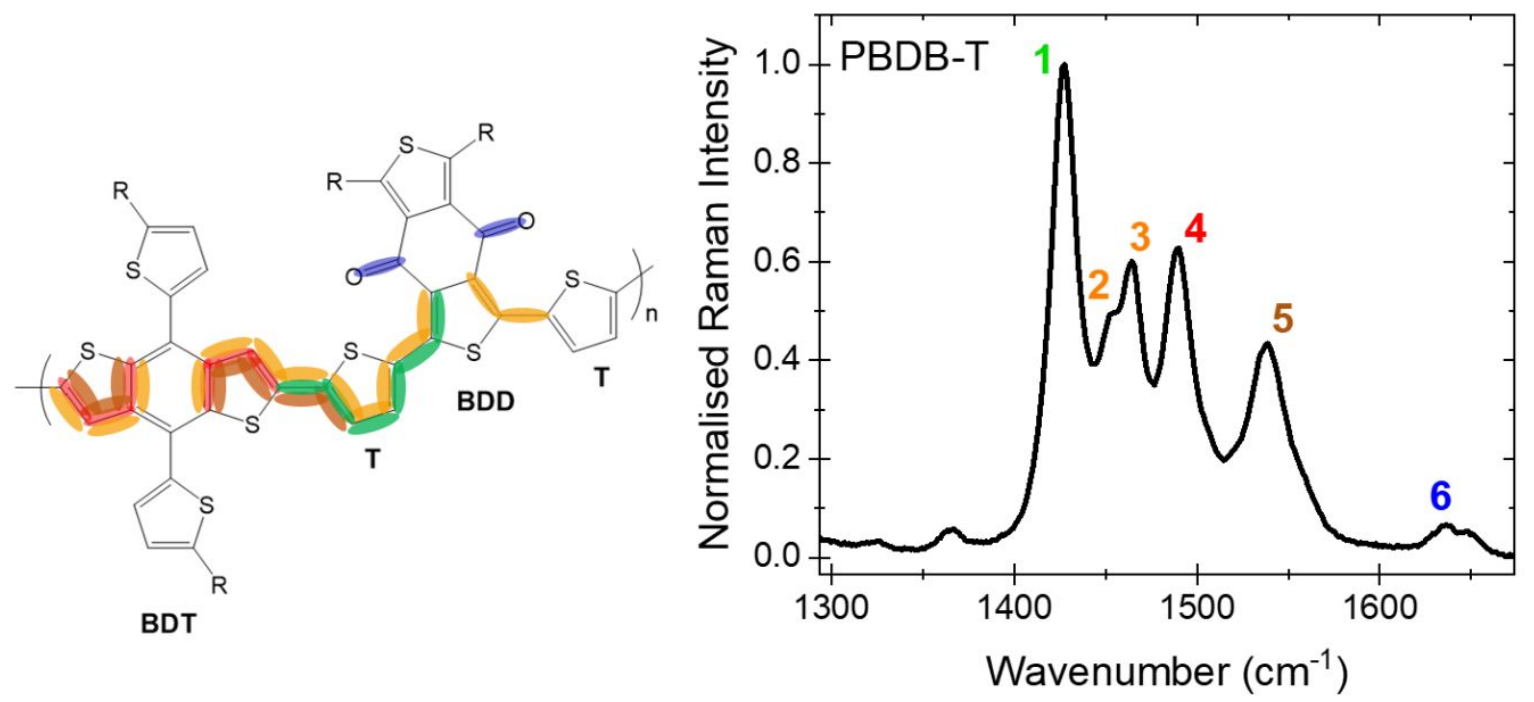

Figure S62. Assignment of Raman modes of PBDB-T indicated on its chemical structure.

\begin{tabular}{|l|l|l|}
\hline & Unit & Description \\
\hline $\mathbf{1}$ & T, BDD & C=C, C-C in T and C-C between T and BDD \\
\hline $\mathbf{2 , 3}$ & BDT, BDD, T & C-C \\
\hline $\mathbf{4}$ & BDT & C-C antisymmetric \\
\hline $\mathbf{5}$ & BDT, T & C-C antisymmetric \\
\hline $\mathbf{6}$ & BDD & Carbonyl \\
\hline
\end{tabular}

Table S3. Description of PBDB-T Raman modes assigned in Figure S60. 

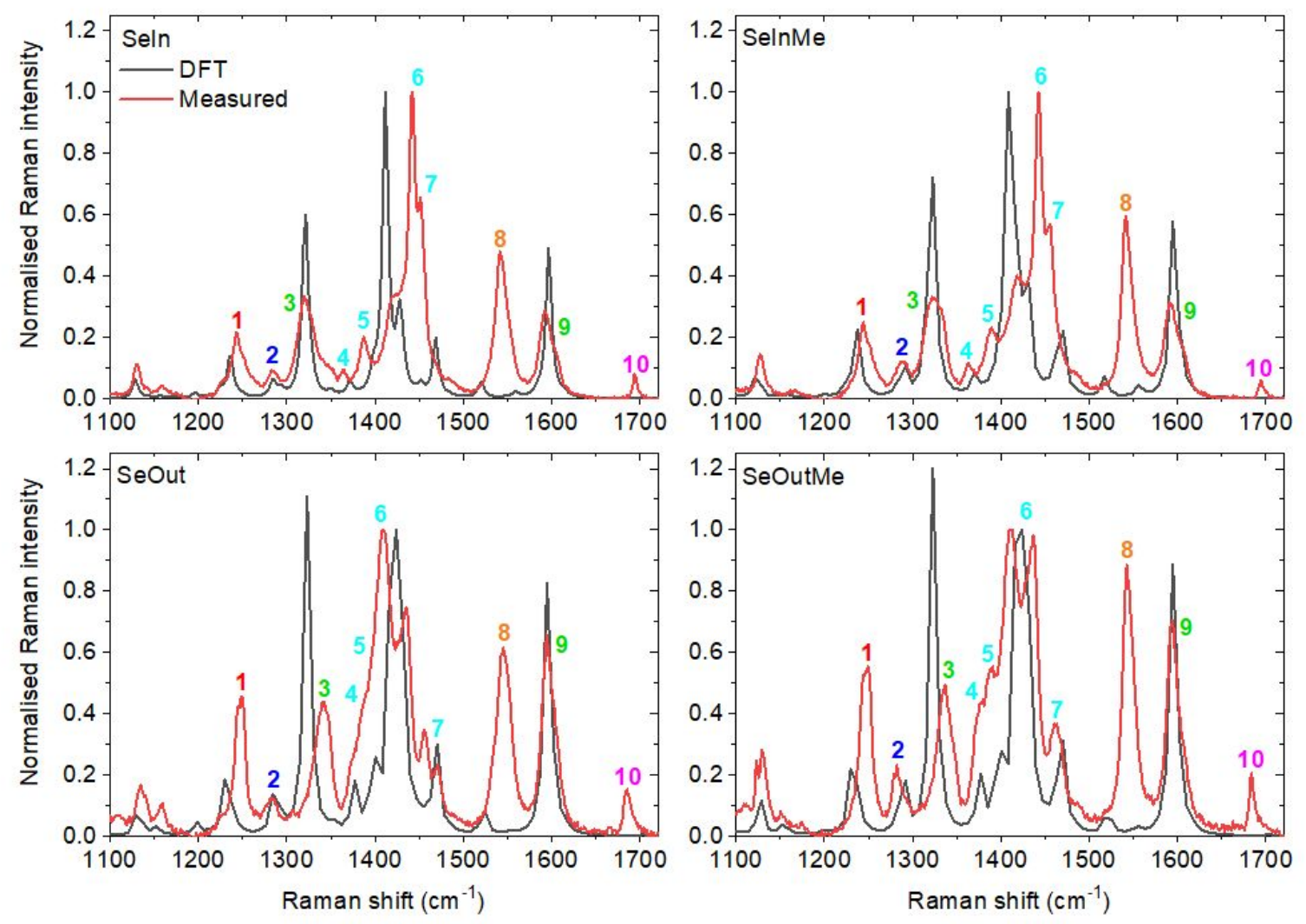

Figure S63. Assignment of the NFA Raman modes, comparing experimental data with DFT simulations. The labels are referred to the detailed description is provided in Table S3. The same color is used to indicate the peaks involving the same molecular bonds. 


\begin{tabular}{|c|c|c|}
\hline Peak & Unit & Description \\
\hline 1 & Core & Core $\mathrm{C}=\mathrm{C}$ symmetric stretch outer thiophene/selenophene \\
\hline 2 & Multiple & $\mathrm{C}-\mathrm{C}$ outer core, $\mathrm{H}$-wagging in flank or interunit $\mathrm{H}$ \\
\hline 3 & Core & $\begin{array}{l}\text { Phenyl - symmetric, minor H-wagging in end phenyl and } \\
\text { alkene }\end{array}$ \\
\hline 4 & Multiple & $\begin{array}{l}\mathrm{C}=\mathrm{C} \text { and } \mathrm{C}-\mathrm{C} \text { outer thiophene/selenophene, alkene } \mathrm{H}- \\
\text { wagging }\end{array}$ \\
\hline 5 & Multiple & $\begin{array}{l}\mathrm{C}=\mathrm{C} \text { and } \mathrm{C}-\mathrm{C} \text { outer thiophene/selenophene, alkene and flank } \\
\mathrm{H} \text {-wagging }\end{array}$ \\
\hline 6 & Core & $\mathrm{C}-\mathrm{C}$ inner thiophene/selenophene \\
\hline 7 & Multiple & $\begin{array}{l}\mathrm{C}=\mathrm{C} \text { outer thiophene/selenophene, alkene and flank } \mathrm{H}- \\
\text { wagging }\end{array}$ \\
\hline 8 & Multiple & Alkenes \\
\hline 9 & Core & Phenyl - antisymmetric \\
\hline 10 & Flank & Carbonyl \\
\hline
\end{tabular}

Table S4. Description of NFA Raman modes assigned in Figure S61. 

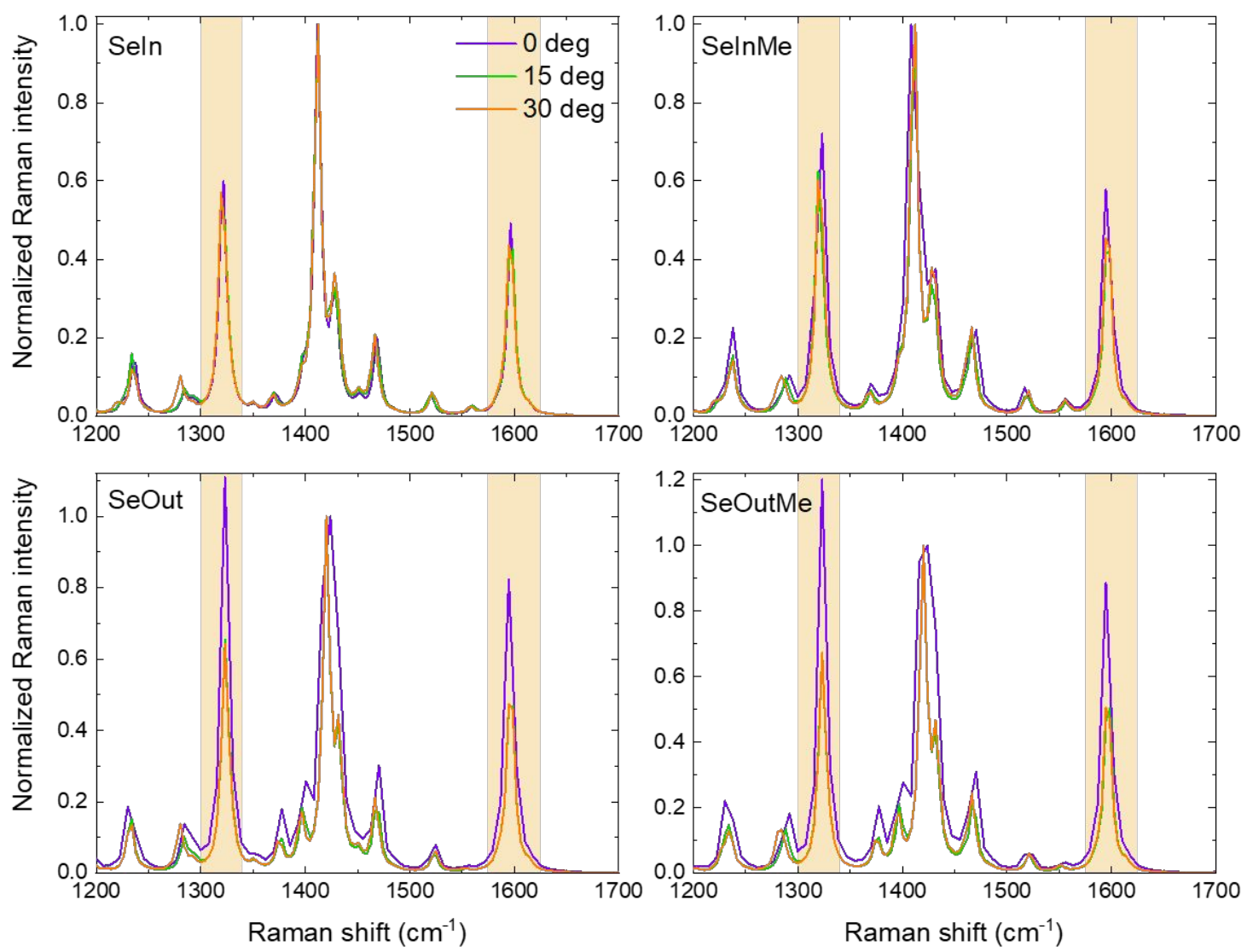

Figure S64. Raman spectra of the four NFAs with different core-end dihedral. The peaks at $\approx 1325$ and $\approx 1600 \mathrm{~cm}^{-1}$ are highlighted and show lower intensity with increasing twisting angle. 

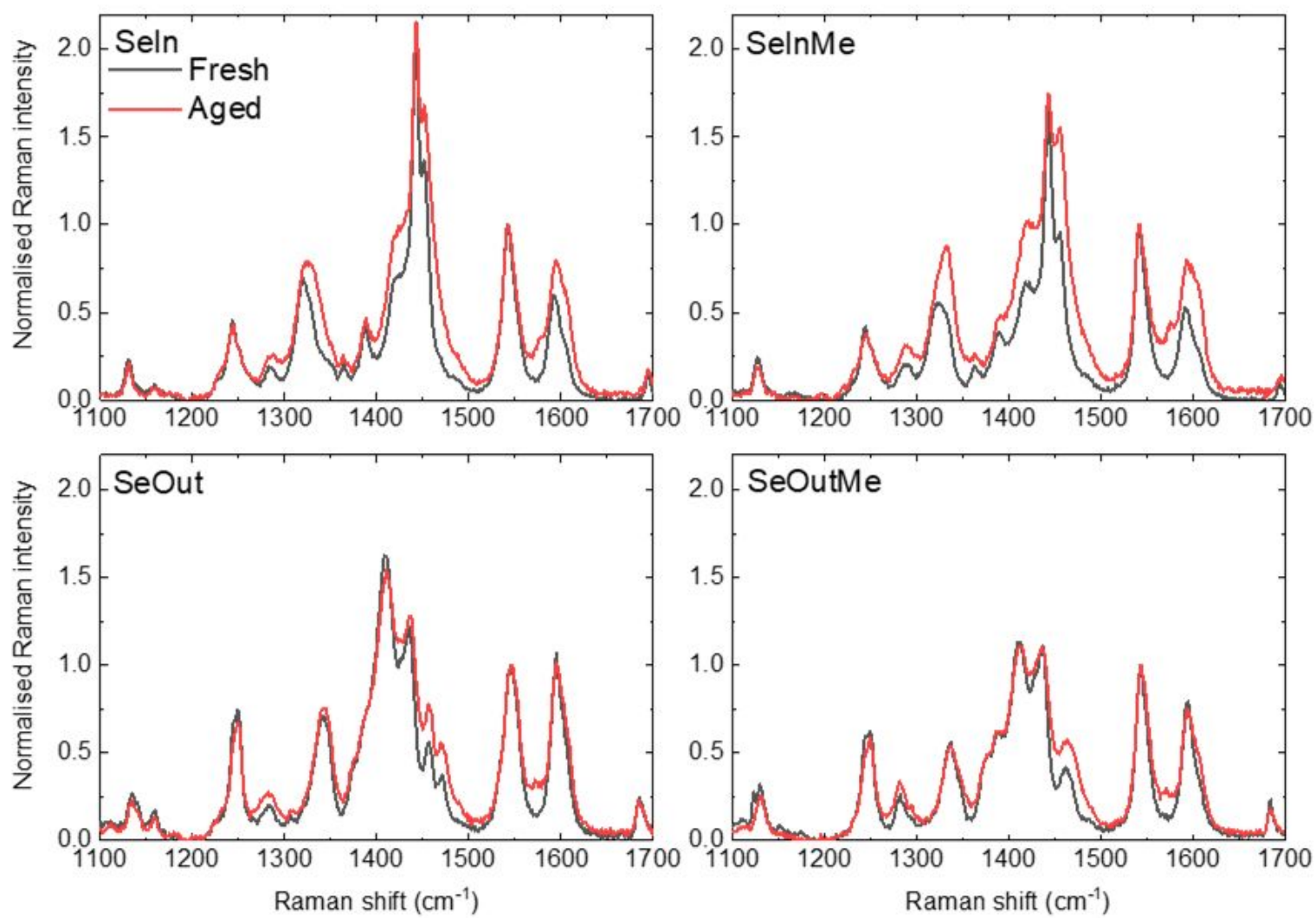

Figure S65. Raman spectra of fresh and light aged neat NFA thin films exposed to white LED light source, probed by $514 \mathrm{~nm}$ laser, normalized with respect to the alkene peak $\left(\approx 1550 \mathrm{~cm}^{-}\right.$ $\left.{ }^{1}\right)$. 

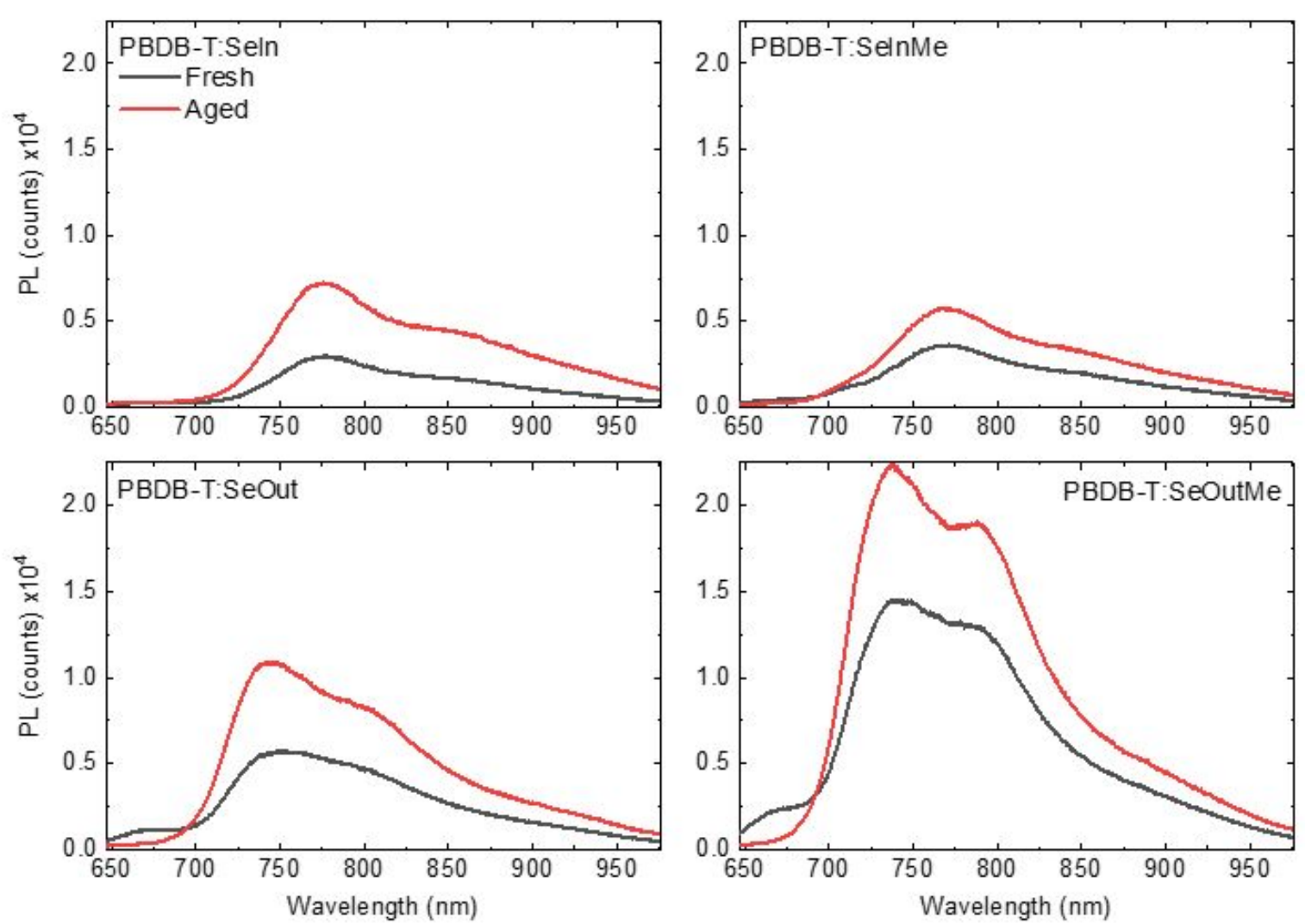

Figure S66. PL spectra of fresh and light aged PBDB-T:NFA blends exposed to white LED light source. 

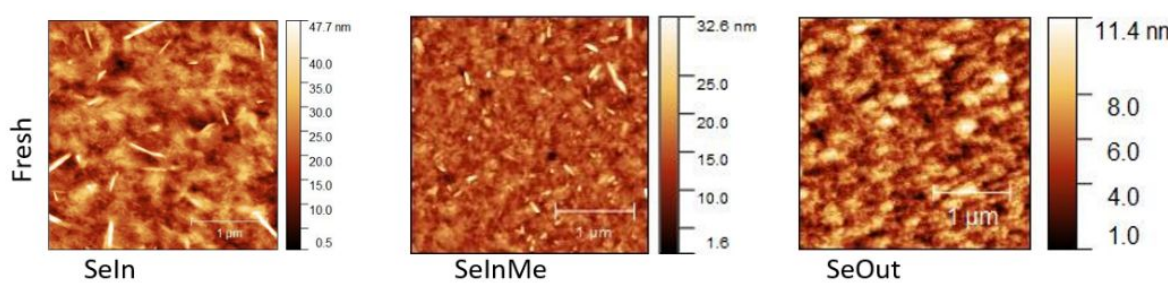

$\mathrm{RMS}=3.073 \mathrm{~nm}$

SeOut

RMS $=1.631 \mathrm{~nm}$

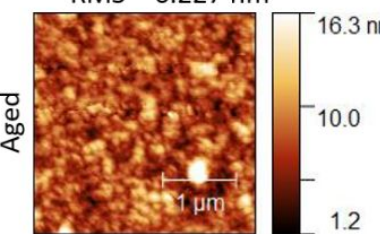

Seln

$\mathrm{RMS}=2.284 \mathrm{~nm}$

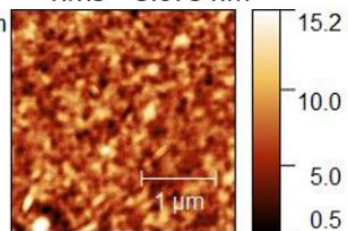

SelnMe

$\mathrm{RMS}=2.108 \mathrm{~nm}$

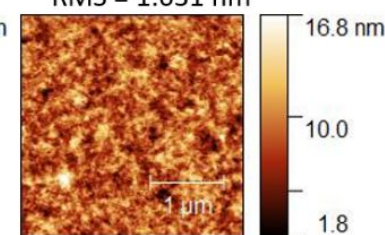

SeOut

RMS $=2.122 \mathrm{~nm}$

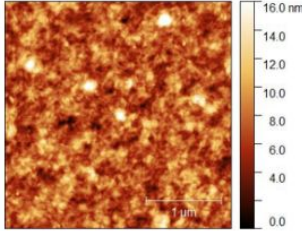

SeOutMe

$\mathrm{RMS}=2.172 \mathrm{~nm}$

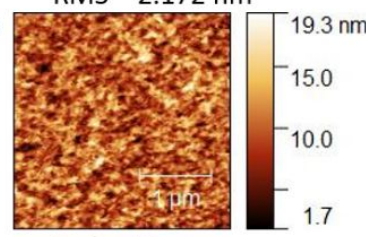

SeOutMe

$\mathrm{RMS}=2.634 \mathrm{~nm}$

Figure S67. AFM maps of surface morphology for fresh and light-aged PBDB-T:NFA blends. 

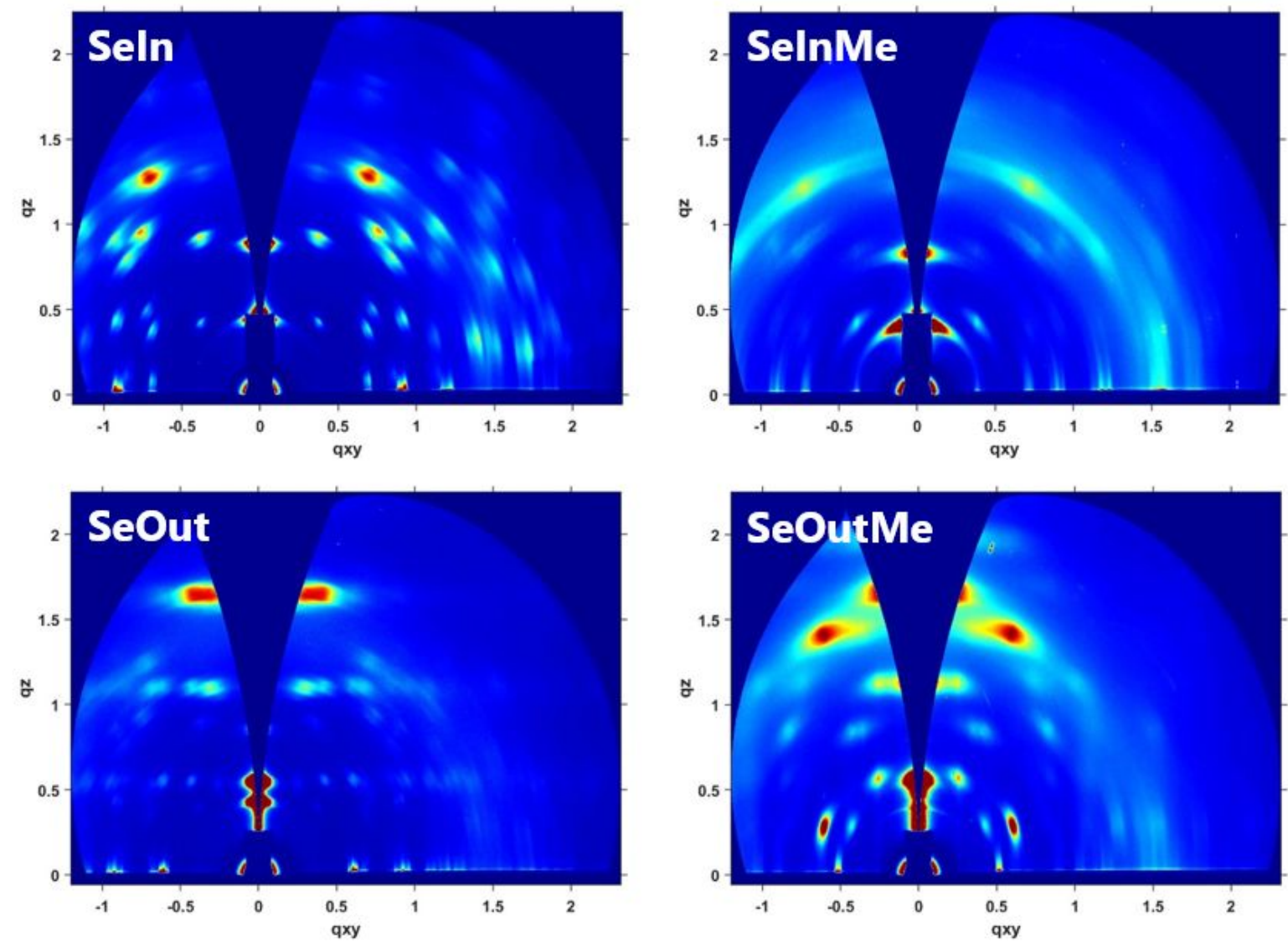

Figure S68. GIWAXS 2D maps for neat NFA thin films
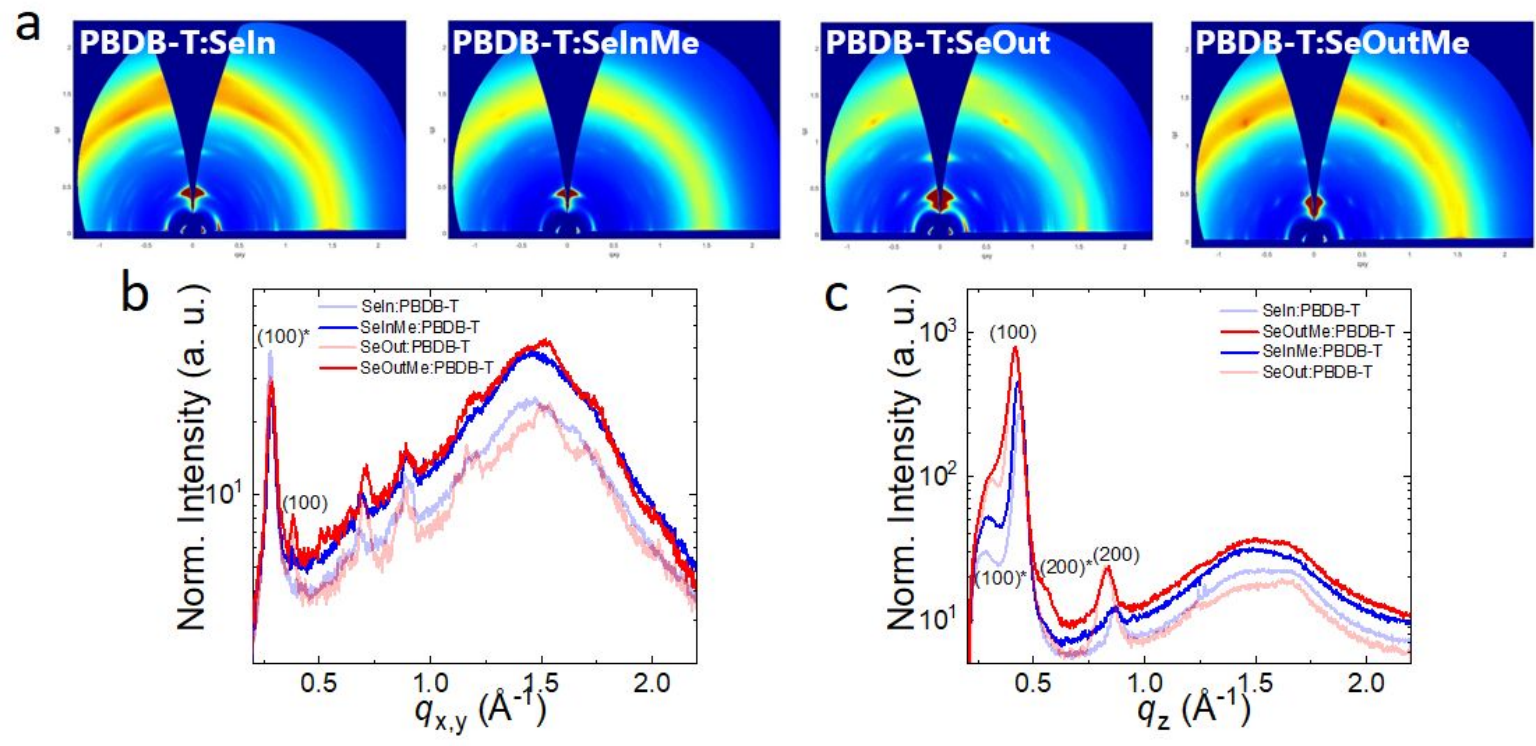

Figure S69. (a) GIWAXS 2D maps for PBDB-T:NFA thin films. In-plane (b) and out-of-plane (c) traces of GIWAXS spectra for PBDB-T:NFA blends. 


\begin{tabular}{|c|c|c|c|c|c|c|}
\hline Parameters & \multicolumn{2}{|c|}{ Neat SeIn } & $\begin{array}{l}\text { SeIn } \\
\text { Blend }\end{array}$ & \multicolumn{2}{|c|}{ Neat SeInMe } & $\begin{array}{c}\text { SeInMe } \\
\text { Blend }\end{array}$ \\
\hline a $(\AA)$ & \multicolumn{2}{|l|}{18.6351} & 16.137 & \multicolumn{2}{|l|}{16.0695} & 17.3045 \\
\hline b $(\AA)$ & \multicolumn{2}{|l|}{10.0687} & 9.7305 & \multicolumn{2}{|l|}{8.676} & 9.6144 \\
\hline c $(\AA)$ & \multicolumn{2}{|l|}{14.2154} & 14.1993 & \multicolumn{2}{|l|}{15.0315} & 14.5917 \\
\hline$\alpha$ (deg.) & \multicolumn{2}{|l|}{90} & 90 & \multicolumn{2}{|l|}{90} & 90 \\
\hline$\beta$ (deg.) & \multicolumn{2}{|l|}{90} & 90 & \multicolumn{2}{|l|}{90} & 90 \\
\hline$\gamma$ (deg.) & \multicolumn{2}{|l|}{116.9} & 108.7 & \multicolumn{2}{|l|}{103.4717} & 109.9188 \\
\hline Space group & \multicolumn{2}{|l|}{ 3. P2 } & 3. $\mathrm{P} 2$ & \multicolumn{2}{|l|}{ 3. $\mathrm{P} 2$} & 3. $\mathrm{P} 2$ \\
\hline Crystal system & \multicolumn{2}{|c|}{ Monoclinic } & Monoclinic & \multicolumn{2}{|c|}{ Monoclinic } & Monoclinic \\
\hline \multirow[t]{2}{*}{ Parameters } & \multicolumn{2}{|c|}{ Neat SeOut } & SeOut & \multicolumn{2}{|c|}{ Neat SeOutMe } & SeOutMe \\
\hline & Phase1 & Phase2 & & Phase1 & Phase2 & \\
\hline a $(\AA \AA)$ & 18.5441 & 27.1434 & 17.1046 & 23.9451 & 23.9451 & 16.5266 \\
\hline b $(\AA)$ & 10.4001 & 16.2975 & 9.1629 & 10.4147 & 14.4507 & 8.9863 \\
\hline c $(\AA)$ & 14.5242 & 11.4157 & 14.8328 & 22.2021 & 22.2021 & 14.9742 \\
\hline$\alpha$ (deg.) & 90 & 90 & 90 & 90 & 90 & 90 \\
\hline$\beta$ (deg.) & 90 & 90 & 90 & 90 & 90 & 90 \\
\hline$\gamma$ (deg.) & 118.0 & 115.2 & 105.9 & 90 & 90 & 103.446 \\
\hline Space group & 3. $\mathrm{P} 2$ & 3. $\mathrm{P} 2$ & 3. P2 & 38. Amm2 & 38. Amm2 & 3. $\mathrm{P} 2$ \\
\hline Crystal system & Monoclin & Monoclinic & Monoclinic & Orthorhombic & Orthorhombic & Monoclinic \\
\hline
\end{tabular}

Table S5. Parameters of the crystalline structure of different NFAs, neat and blended with PBDB-T, extracted from GIWAXS data, with in bold the lattice parameters mostly affected by blending in SeOutMe system. 


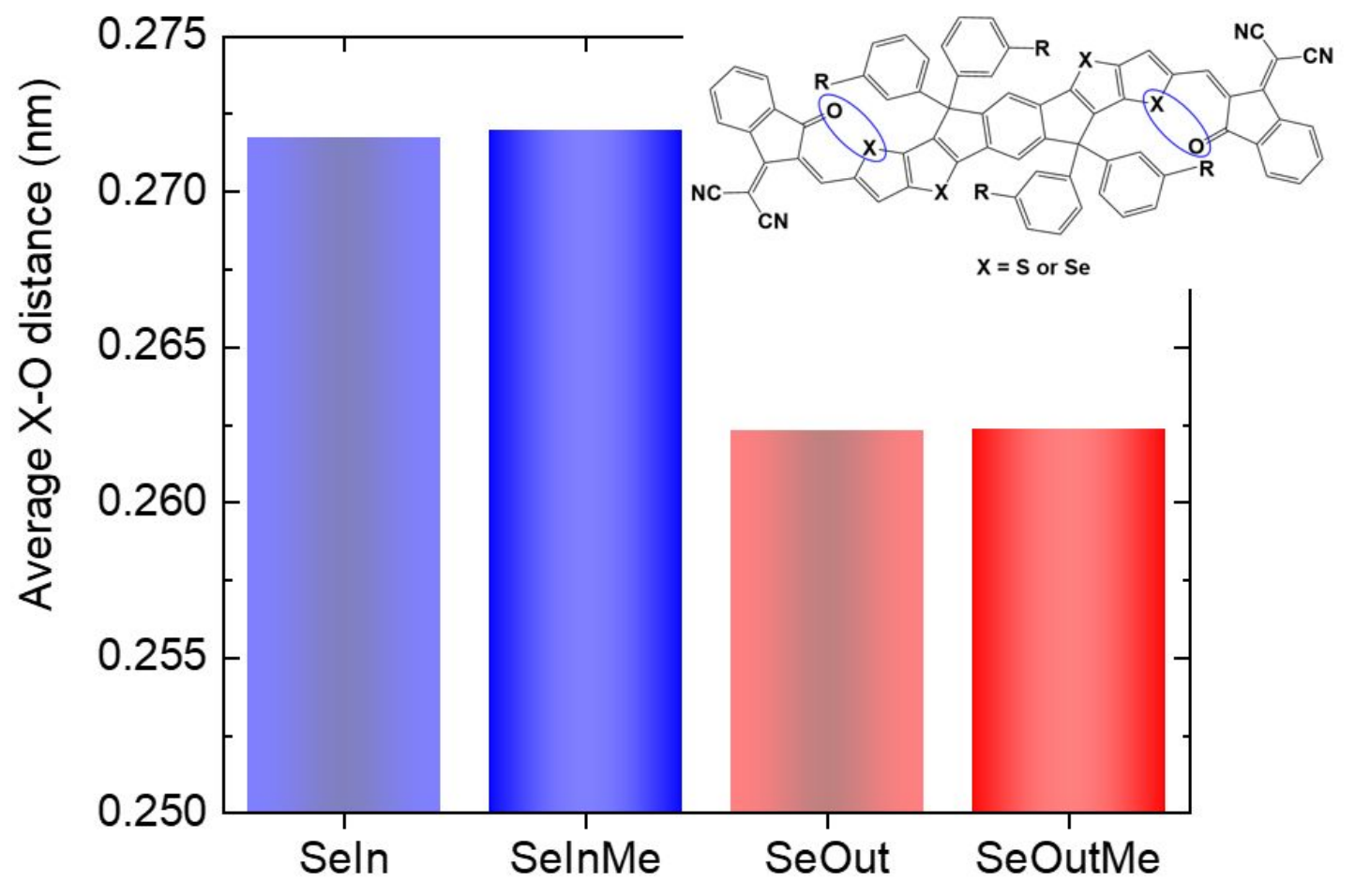

Figure S70. Average interatomic distance between oxygen and the outer chalcogen in the NFA core (see chemical structure in the inset) from the DFT energy optimized structure. 


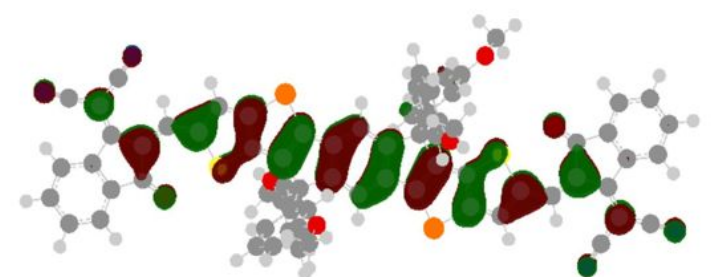

Seln

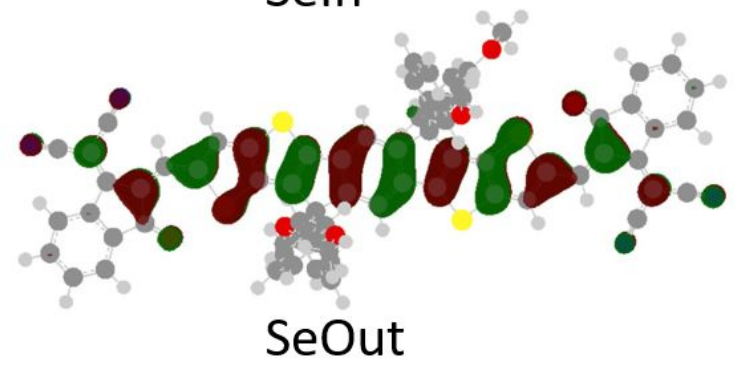

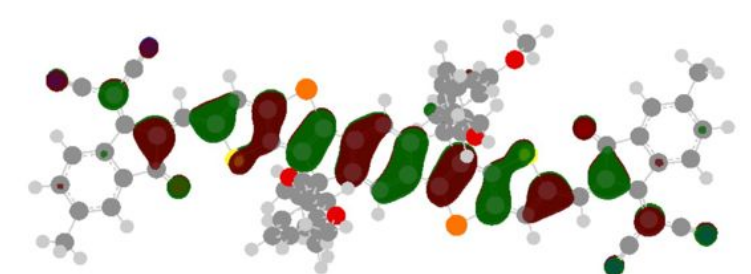

SelnMe

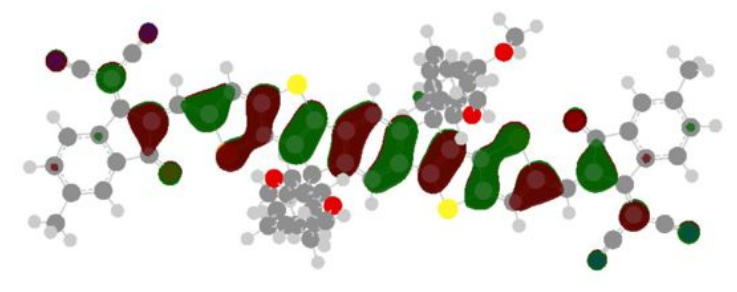

SeOutMe

Figure S71. HOMO distributions for DFT energy optimized structures of different NFAs.

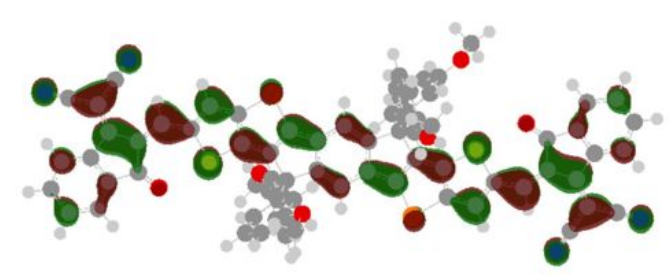

Seln

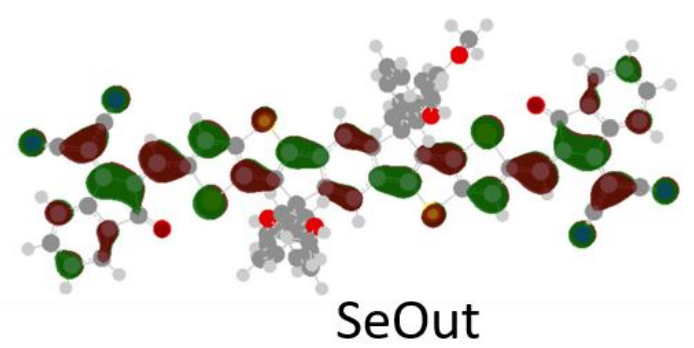

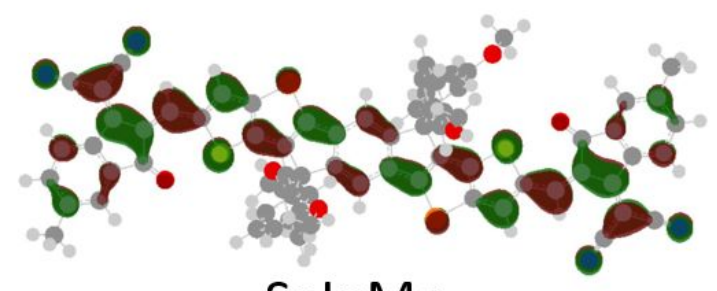

SelnMe

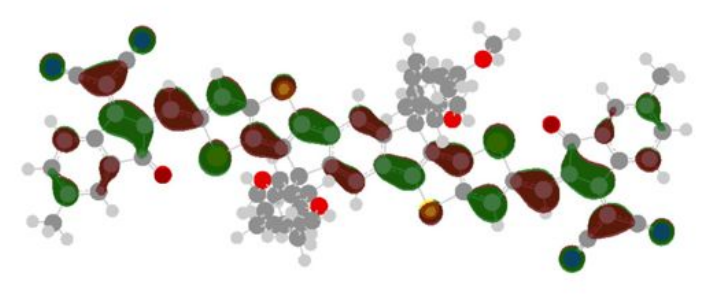

SeOutMe

Figure S72. LUMO distributions for DFT energy optimized structures of different NFAs. 


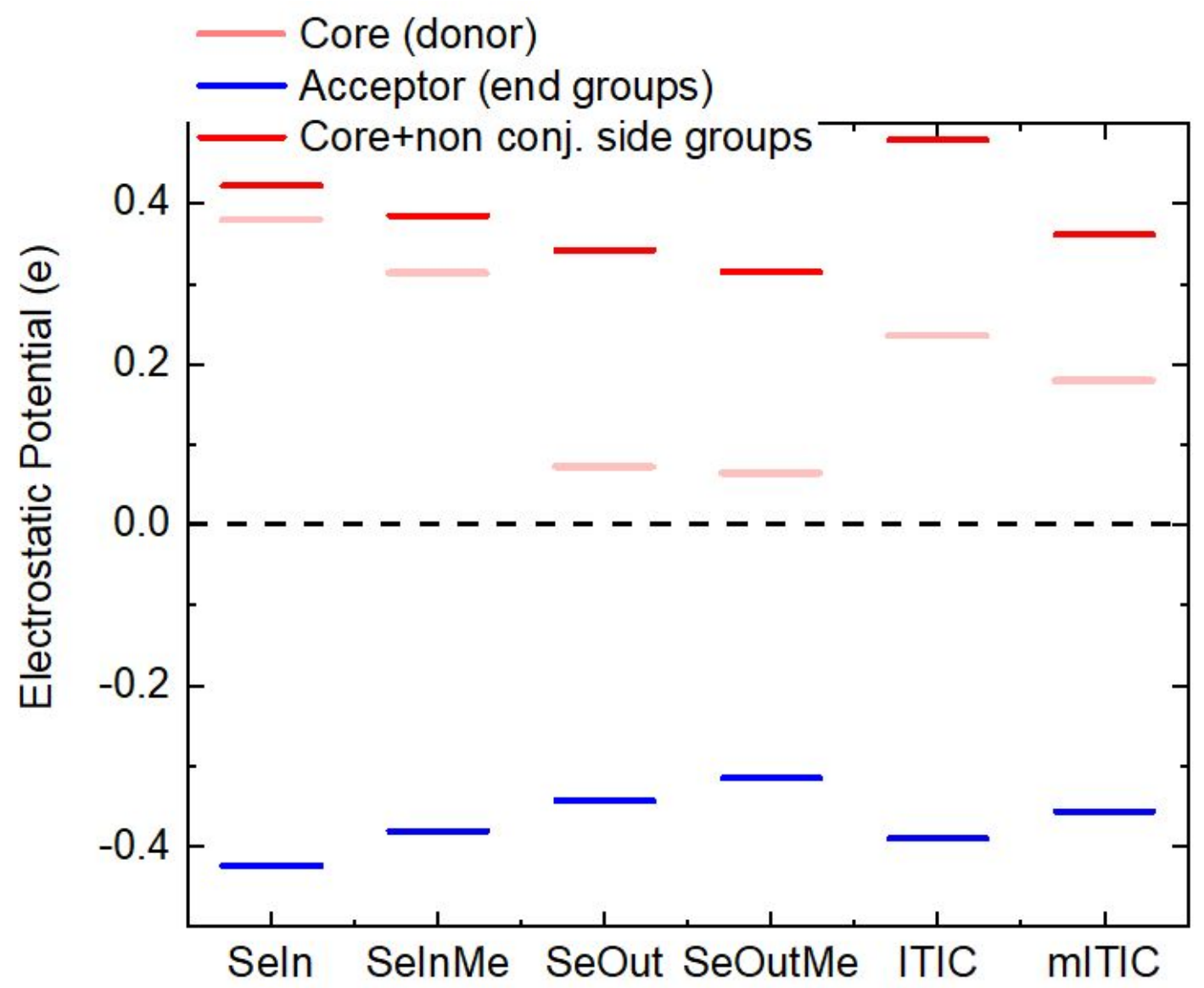

Figure S73. Electrostatic potential for core and end regions extracted by Merz-Kollman model for DFT energy optimized structures of different NFAs. 


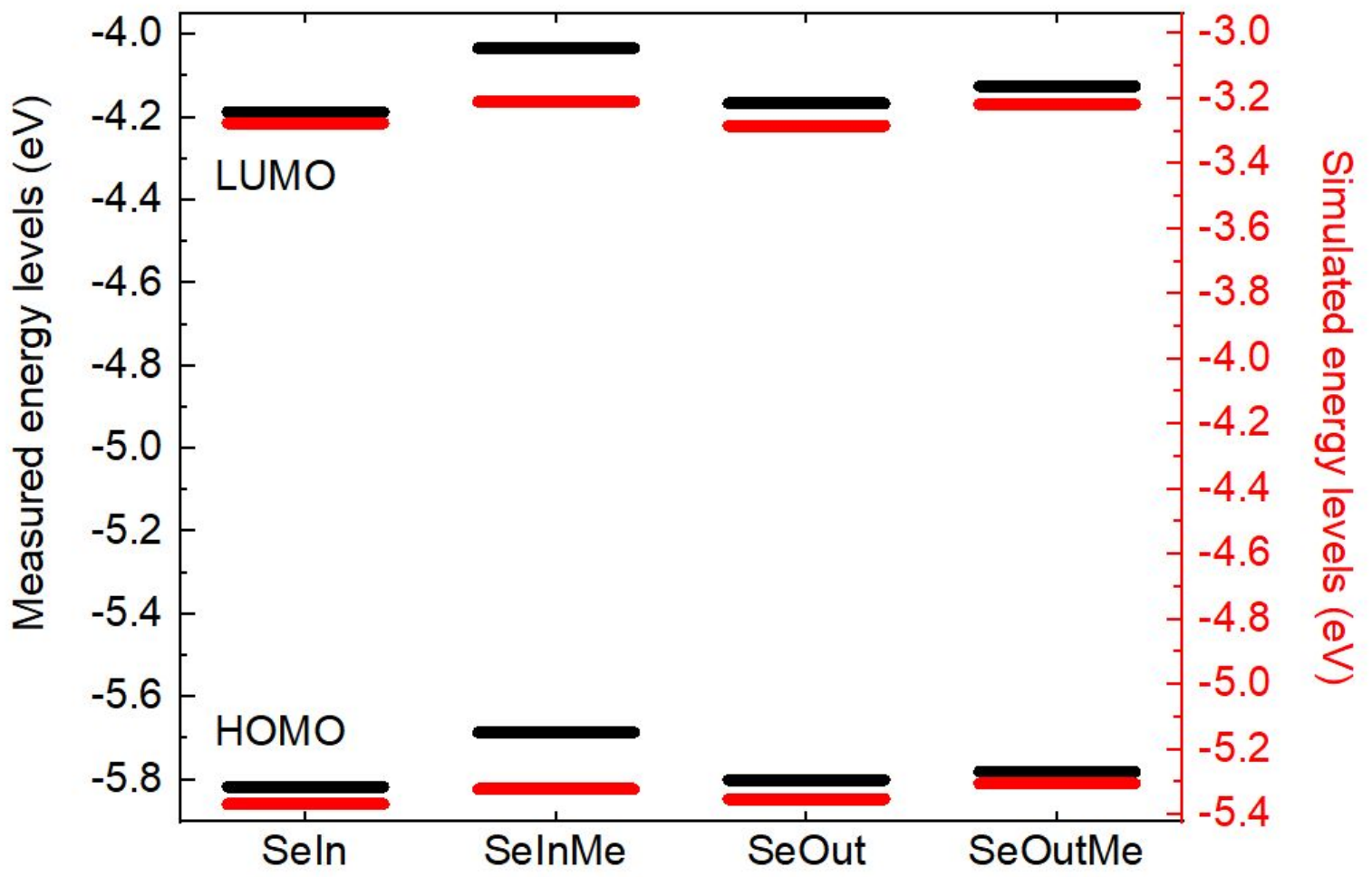

Figure S74. HOMO and LUMO energy levels for the different neat NFAs, comparing the experimental results (measured by APS + optical bandgap) with the simulated values (DFT). 


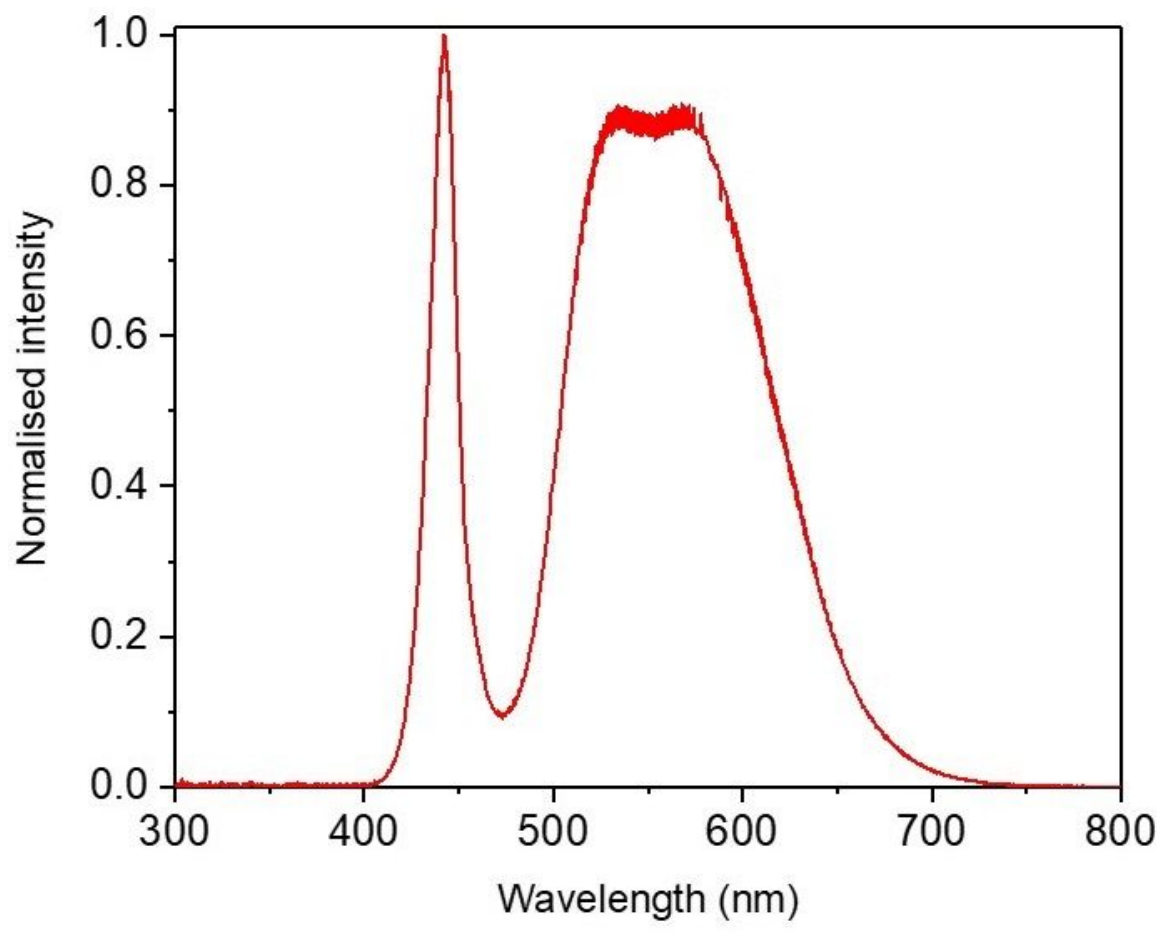

Figure S75. Illumination spectral distribution of the white LED source used for light aging experiment.

\section{REFERENCES}

(1) Mishra, S.P.; Javier, A.E.; Zhang, R.; Liu, J.; Belot, J.A.; Osaka, I.; McCullough, R.D. Mixed Selenium-Sulfur Fused Ring Systems as Building Blocks for Novel Polymers Used in Field Effect Transistors. J. Mater. Chem. 2011, 21, 1551-1561. 